\title{
British Virgin Islands: Financial Sector Assessment Program Update—Financial System Stability Assessment
}

This Financial System Stability Assessment on British Virgin Islands was prepared by a staff team of the International Monetary Fund as background documentation for the periodic consultation with the member country. It is based on the information available at the time it was completed in April 2010. The views expressed in this document are those of the staff team and do not necessarily reflect the views of the government of British Virgin Islands or the Executive Board of the IMF.

The policy of publication of staff reports and other documents by the IMF allows for the deletion of market-sensitive information.

Copies of this report are available to the public from

International Monetary Fund $\bullet$ Publication Services

700 19th Street, N.W. • Washington, D.C. 20431

Telephone: (202) 6237430 • Telefax: (202) 6237201

E-mail: publications@imf.org • Internet: http://www.imf.org

\section{International Monetary Fund Washington, D.C.}




\title{
INTERNATIONAL MONETARY FUND
}

\author{
BRITISH VIRGIN ISLANDS
}

Financial System Stability Assessment

\author{
Prepared by the Monetary and Capital Markets and European Departments \\ Approved by José Viñals and Ajai Chopra
}

October 2010

This report contains the main findings and recommendations of an IMF Financial Sector Assessment Program (FSAP) mission that visited the British Virgin Islands at the invitation of authorities during the period April 12-21, 2010. The mission comprised Jennifer Elliott (mission chief) and Katharine Seal (both MCM/IMF); Michael Deasy (Central Bank of Ireland) and José Tuya (both banking supervision experts); Tanis MacLaren (securities regulation expert); and Robin Sykes (Bank of Jamaica, trust and corporate services provider expert).

The registration of offshore corporations and trusts, including financial holding companies; asset management companies; and captive insurers; is the main financial service provided in the BVI. As such, the chief risk to the financial sector is reputational. The authorities are keenly attuned to this risk and have in place a sound system of surveillance and enforcement to combat risk. The banking system is quite small and largely local; banks, branches, and subsidiaries are well capitalized, very liquid, and well supervised; but there is a need to enhance the crisis management framework. Recommendations from the 2004 Offshore Financial Center assessment report have largely been addressed.

The report made a number of recommendations including:

- $\quad$ Prompt and full implementation of the Regulatory Code.

- $\quad$ Prompt and full implementation of the new Securities Investment Business Act.

- $\quad$ Provide additional resources for on-site review of corporate and trust service providers.

- Increase the fine amounts contained in financial laws.

A separate Caribbean Financial Action Task Force (CFATF) mission completed its assessment of the FATF anti-money laundering and combating the financing of terrorism (AML/CFT) standards in December 2008 and produced a Report on Standards and Codes (ROSC) from this assessment, appended to this report.

FSAP assessments are designed to assess the stability of the financial system as a whole and not that of individual institutions. They have been developed to help countries identify and remedy weaknesses in their financial sector structure, thereby enhancing their resilience to macroeconomic shocks and cross-border contagion. FSAP assessments do not cover risks that are specific to individual institutions such as asset quality, operational or legal risks, or fraud. 
Contents Page

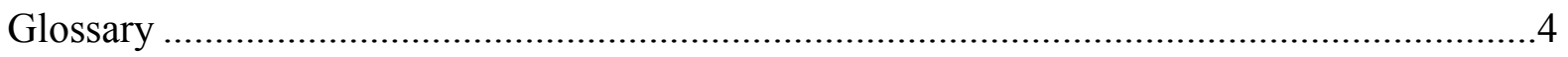

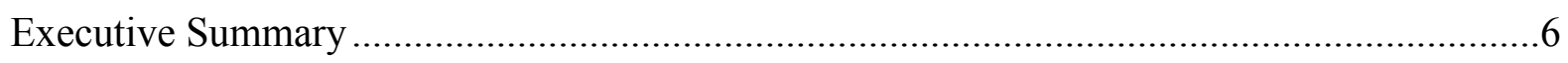

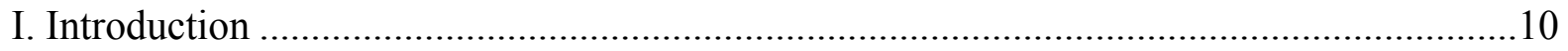

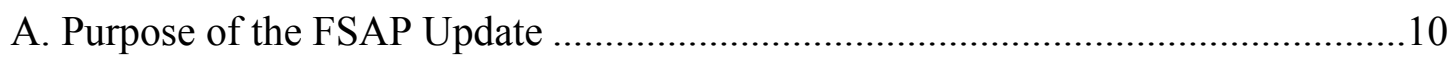

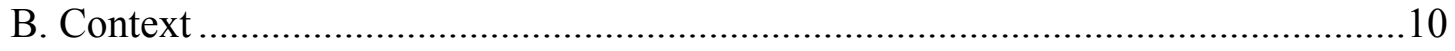

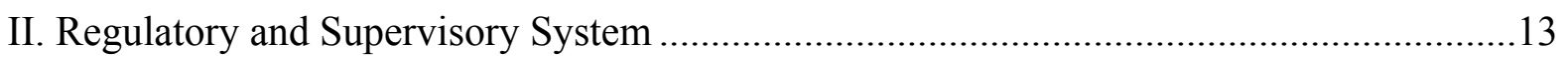

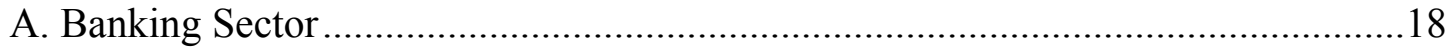

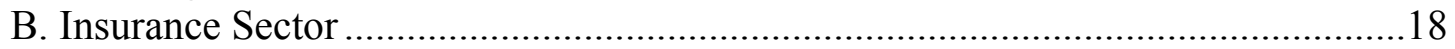

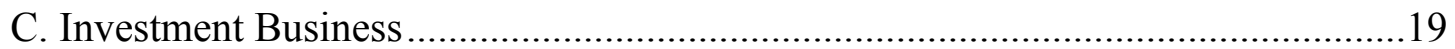

D. Trust and Corporate Service Providers ........................................................... 21

E. International Information Sharing and Cooperation............................................24

F. Anti Money-Laundering and Combating the Financing of Terrorism ...................25

III. Financial Stability Issues ........................................................................................26

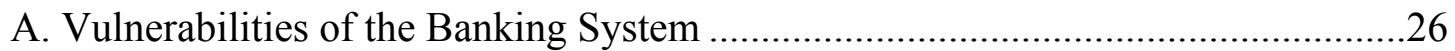

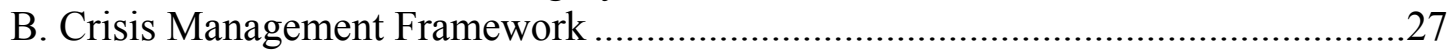

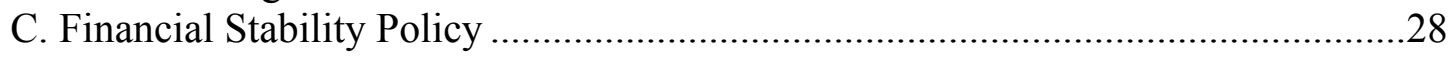

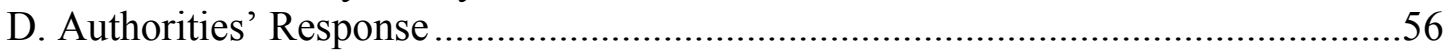

Tables

1. Risk Assessment Matrix ................................................................................ 7

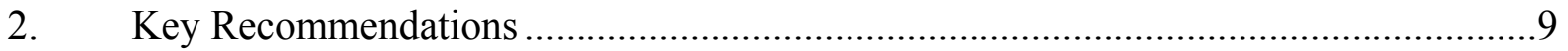

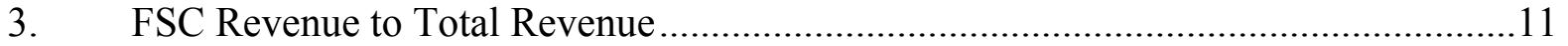

4. Structure of the Financial Sector - Current .......................................................... 13

5. FSC Annual Staff Count .................................................................................. 15

6. On-site Inspections Conducted by FSC Regulatory Divisions .................................17

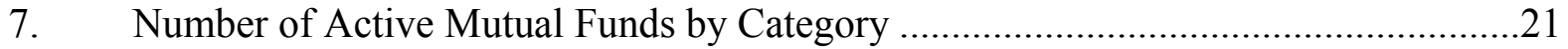

8. Number of Active Fund Managers and Administrators by Category ........................21

9. Information Sharing under the IOSCO MMOU ....................................................25

10. Bank Liquidity (Aggregate) ...............................................................................27

11. Summary Compliance with the Basel Core Principles_-ROSCs ..............................36

12. Recommended Action Plan to Improve Compliance with the Basel Core Principles 40

13. Summary Table of Observance and Key Recommendations ....................................52

14. Authorities' Response ....................................................................................56

15. Financial Soundness Indicators for the Banking Sector-Commercial Banks ..........75

16. Recommended Action Plan to Improve Observance of IAIS Insurance Core.............78

17. Recommendations Related to the IOSCO Principles Assessment.............................83

18. Recommendations Relevant to the IBC and Trust and Company .............................89

19. Recommended Action Plan to Improve Compliance of the Basel Core....................92 
Annex

Observance of Financial Supervision Standards and Codes-Summary Assessments.....

\section{Appendixes}

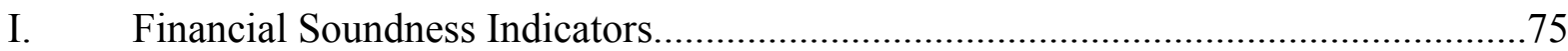

II. Implementation of the Recommendations of the 2004 Assessment .........................76 


\section{GLOSSARY}

ADVCTF

AML/CFT

AMLR

AMLTFCOP

ATFOMOTO

ATUNMOTO

BCP

BCBS

BCA

BRIC

BTCA

BVIBCA

CAR

CDD

CFATF

CFT

CGBS

CIS

CMA

DCS

DNFBP

DPP

DTOA

FATF

FIA

FIAA

FSAP

FSSA

FSB

FSC

FSCA

GDP

IA

IADI

IAIS

IBC

ICP

IMF
Anti-Drug and Violent Crimes Task Force

Anti-Money Laundering and Combating the Financing of Terrorism

Anti-Money Laundering Regulations, 2008

Anti-Money Laundering and Terrorist Financing Code of Practice

Anti-Terrorism (Financial and Other Measures) (Overseas Territories)

Order, 2001

Al-Qa'ida and Taliban (United Nations Measures) (Overseas

Territories) Order, 2002

Basel Core Principles for Effective Banking Supervision

Basel Committee on Banking Supervision

BVI Business Company Act

Brazil, Russian, India and China

Banks and Trust Companies Act

British Virgin Islands Business Companies Act, 2004

Capital adequacy ratio

Customer Due Diligence

Caribbean Financial Action Task Force

Combating the Financing of Terrorism

Caribbean Group of Banking Supervisors

Collective Investment Scheme

Company Management Act

Depositor Compensation Scheme

Designated Non-Financial Businesses and Professions

Director of Public Prosecutions

Drug Trafficking Offences Act

Financial Action Task Force

Financial Investigations Agency

Financial Investigation Agency Act, 2003

Financial Sector Assessment Program

Financial System Stability Assessment

Financial Stability Board

Financial Services Commission

Financial Services Commission Act

Gross Domestic Product

Insurance Act, 2008

International Association of Deposit Insurers

International Association of Insurance Supervisors

International Business Corporation

Insurance Core Principles

International Monetary Fund 
IOSCO

JALTFAC

LOLR

MD

ML

MOU

NAV

NPO

OFC

OGBS

OSFI

POCCA

RA

$\mathrm{RC}$

ROSC

RVIPF

SARs

SIBA

SIV

SPV

TCSP

TF

TUNMOTO
International Organization of Securities Commissions

Joint Anti-Money Laundering and Terrorist Financing Advisory

Committee

Lender of last resort

Managing Director of the FSC

Money Laundering

Memorandum of understanding

Net asset value

Non-profit Organization

Offshore Financial Center

Offshore Group of Banking Supervisors

Office of the Superintendent of Financial Institutions

Proceeds of Criminal Conduct Act, 1997

Registered Agent

Regulatory Code, 2009

Reports on Observance of Standards and Code

Royal Virgin Islands Police Force

Suspicious Activity Reports

Securities and Investment Business Act, 2010

Structured investment vehicle

Special purpose vehicle

Trust and corporate service providers

Terrorist Financing

Terrorism (United Nations Measures) (Overseas Territories) Order, 2001 


\section{EXECUTIVE SUMMARY}

This report updates the findings of the 2004 assessment under the Offshore Financial Center (OFC) program, while concentrating on priorities going forward. The focus is on financial regulatory policies and financial stability. A great deal of progress has been made in strengthening the regulatory system, in particular in developing effective enforcement. The legislative framework is now comprehensive and compliant with international standards and the work to ensure full implementation of this framework is ongoing.

The British Virgin Islands (BVI) hosts the largest registry of international companies in the world and, thus, holds an important place in the global financial infrastructure. The central business of the jurisdiction is to incorporate companies and trusts that are financial holding companies; asset management companies; captive insurers; and the like. Most of the 400,000 registered companies undertake all of their financial activities outside of the BVI, which is to say that money and transactions do not flow through the BVI, unlike in other offshore centers. The BVI provides administrative; audit; and legal services to international business companies, and these ancillary services are another key component of the economy. Financial services in the BVI are otherwise fairly limited, comprising local banking and insurance companies.

The chief threat to the thriving offshore business is the loss of reputation internationally and the authorities are well attuned to this risk. The BVI's continued ability to attract company registration business relies on its being viewed internationally as a well-regulated and policed jurisdiction with a strong legal framework and efficient corporate services. The jurisdiction has been quick to adopt international standards as they evolve. Since the previous assessment, the Financial Services Commission (FSC) has significantly strengthened its supervision function, a key to avoiding operational problems that would damage the jurisdiction's reputation. The FSC devotes significant attention to international information sharing and cooperation, for example, in signing the International Organization of Securities Commissions (IOSCO) multilateral memorandum of understanding (MMOU) for information sharing, and tightly monitors the territory's image abroad.

The regulatory framework for both onshore and offshore financial services is clear and comprehensive, and the FSC has demonstrated its strength and independence as a regulator-however, additional focus on implementation of new rules would strengthen supervision. There is a full suite of legislation and a recently adopted FSC Regulatory Code, which codifies existing regulatory guidance. The FSC has enhanced its supervisory program since the 2004 assessment with on-site inspections. The FSC has a strong regime of on- and off-site supervision. However, there is still a need to improve the pace of implementation of reforms - much of the new legislation noted in the report took many years to enact. The FSC must continuously review and respond to the increased complexity of regulation and the market place. Further, there is a need to communicate the implementation of new rules promptly and clearly, and to dedicate more resources to on-site inspections. 
The heavy reliance on the financial services industry for revenue in the territory creates significant pressure on the FSC to continuously update and adopt regulatory practice that is credible internationally, as well as practical in the jurisdiction. Since future growth in financial services is likely to be at the more complex end of the spectrum, this will necessitate capacity building at the FSC. The recent Securities Investment Business Act, for example, expands the scope for services, but there is little preparation to implement these opportunities.

The banking system has been insulated from global financial shocks to date and has remained stable. The system is focused on domestic activity and was not directly exposed to volatile asset markets. Only one bank is locally owned and the remainder of the system is comprised of branches and subsidiaries of foreign banks. Distress experienced by the parent banking institutions is a potential source of transmission of shocks with adverse effects on the BVI branches and subsidiaries. Moreover, the BVI banking system is highly concentrated with two branches having approximately half of the deposit and loan markets of territory

Crisis management planning for the local banking system should be addressed. Although there is limited scope for many aspects of crisis management (liquidity provision, etc.), the authorities should be prepared to take whatever actions they can to protect depositors. A deposit insurance scheme is being planned for the jurisdiction as a step in this direction.

Table 1. British Virgin Islands: Risk Assessment Matrix

\begin{tabular}{|c|c|c|}
\hline Threat & Likelihood Considerations & Impact Considerations \\
\hline $\begin{array}{l}\text { Being } \\
\text { designated a } \\
\text { noncooperative } \\
\text { jurisdiction } \\
\text { under Financial } \\
\text { Stability Board } \\
\text { rules or FATF }\end{array}$ & $\begin{array}{l}\text { Assessment: Low } \\
\text { The BVI has worked steadily to decrease } \\
\text { the risk of being considered a } \\
\text { noncooperative jurisdiction according to } \\
\text { international standards. It signed the } \\
\text { IOSCO MMOU in 2008, which gives it } \\
\text { cooperative status for the purposes of } \\
\text { sharing information with securities } \\
\text { regulators (and ensures that it has been } \\
\text { rigorously screened for authority to obtain } \\
\text { and share financial information). Under its } \\
2004 \text { assessment the BVI had two } \\
\text { relevant materially noncompliant ratings } \\
\text { under the new Financial Stability Board } \\
\text { (FSB) list. However, the BCP assessment } \\
\text { in } 2010 \text { has generated no materially } \\
\text { noncompliant ratings. The anti money- } \\
\text { laundering and combating the financing of } \\
\text { terrorism (AML/CFT) assessment }\end{array}$ & $\begin{array}{l}\text { Assessment: High } \\
\text { Designation as an uncooperative } \\
\text { jurisdiction would have serious } \\
\text { consequences for the BVI. Such a } \\
\text { designation impairs its ability to attract } \\
\text { and retain offshore business, } \\
\text { particularly in the corporate trust } \\
\text { services and asset management } \\
\text { sectors. These sectors are key to its } \\
\text { financial sector success. }\end{array}$ \\
\hline
\end{tabular}




\begin{tabular}{|c|c|c|}
\hline & $\begin{array}{l}\text { produced no concerns. The BVI has been } \\
\text { added to the white list and continues to } \\
\text { pursue cooperation as a first priority. }\end{array}$ & \\
\hline $\begin{array}{l}\text { Cross-border } \\
\text { cooperation } \\
\text { (whole sector) }\end{array}$ & $\begin{array}{l}\text { Assessment: Medium } \\
\text { The BVI has been very attentive to its role } \\
\text { as a provider of information to other } \\
\text { supervisors and has taken care to ensure } \\
\text { that it is regarded as cooperative. } \\
\text { However, the pressure from larger } \\
\text { countries, who perceive offshore centers } \\
\text { as uncooperative or intransparent, } \\
\text { continues. The BVI will have to adapt to } \\
\text { all new requirements for information } \\
\text { sharing, including tax information. }\end{array}$ & $\begin{array}{l}\text { Assessment: High } \\
\text { The BVI is vulnerable to a loss of } \\
\text { reputation as a cooperative and } \\
\text { reputable offshore center if it fails to } \\
\text { remain cooperative with other } \\
\text { jurisdictions. Loss of reputation would } \\
\text { result in a contraction of registration of } \\
\text { companies, which is the chief source of } \\
\text { revenue in the financial sector. }\end{array}$ \\
\hline $\begin{array}{l}\text { Financial } \\
\text { difficulties of } \\
\text { government- } \\
\text { owned bank }\end{array}$ & $\begin{array}{l}\text { Assessment: Medium Low } \\
\text { The government-owned bank is in } \\
\text { transition from a development bank to a } \\
\text { commercial bank and, although capital } \\
\text { levels remain sound, its profitability has } \\
\text { decreased. It does not have recourse to } \\
\text { sources of liquidity if it were to come } \\
\text { under pressure. If it runs into difficulty, } \\
\text { this has the potential to create a } \\
\text { disruption in the provision of banking } \\
\text { services. However, given that its activities } \\
\text { are limited to traditional deposit taking } \\
\text { and local lending, there is little risk of } \\
\text { spillover. Further, the FSC has been } \\
\text { working with the bank to improve } \\
\text { management and it is subject to normal } \\
\text { regulation and supervision. }\end{array}$ & $\begin{array}{l}\text { Assessment: Medium Low } \\
\text { At the extreme, if the bank were to fail, } \\
\text { it could cause losses for local } \\
\text { depositors. It would not, however, have } \\
\text { a great deal of impact on the rest of the } \\
\text { sector, which, for the most part, does } \\
\text { not transact money through local } \\
\text { banks. Further, it would have a limited } \\
\text { impact on the real economy, as it does } \\
\text { not finance tourism or financial services } \\
\text { to a significant degree. } \\
\text { The U.K. government has indicated } \\
\text { very firmly that it would not extend } \\
\text { financial help for a bank in trouble (and } \\
\text { has carried that through in other } \\
\text { overseas territories). At the moment, } \\
\text { the BVI government cannot borrow } \\
\text { money in order to rescue a bank (due } \\
\text { to fiscal constraints). The government is } \\
\text { aware of this issue, as is the FSC, and } \\
\text { the current strategy is to constrain the } \\
\text { expansion of the bank and to require its } \\
\text { business to remain very conservative. }\end{array}$ \\
\hline $\begin{array}{l}\text { Pressure on } \\
\text { liquidity of } \\
\text { branches and } \\
\text { subsidiaries of } \\
\text { large groups }\end{array}$ & $\begin{array}{l}\text { Assessment: Low } \\
\text { The retail and commercial banking sector } \\
\text { is dominated by branches and } \\
\text { subsidiaries of four global banking } \\
\text { groups, (with } 40 \text { percent of deposits held } \\
\text { in a subsidiary of a Canadian group). If } \\
\text { the parent banks were to come under } \\
\text { pressure and draw liquidity up from the } \\
\text { local branch/subsidiary, BVI depositors } \\
\text { would be at risk. Currently, each of these }\end{array}$ & $\begin{array}{l}\text { Assessment: Medium } \\
\text { There is a risk for BVI subs and } \\
\text { branches if parent banks come under } \\
\text { financial pressure. These branches and } \\
\text { subs are currently highly liquid and well } \\
\text { capitalized. } \\
\text { The risk remains low, but there would } \\
\text { be an impact on local depositors, with } \\
\text { spillovers to the jurisdiction in terms of }\end{array}$ \\
\hline
\end{tabular}




\begin{tabular}{|l|l|l|}
\hline $\begin{array}{l}\text { branches and subsidiaries are highly } \\
\text { liquid and well capitalized. The FSC has } \\
\text { good relations with home supervisors. In } \\
\text { an emergency, the FSC could impose } \\
\text { local liquidity requirements. The } \\
\text { jurisdiction is also working toward a } \\
\text { deposit insurance scheme as a first } \\
\text { defense against liquidity runs. }\end{array}$ & $\begin{array}{l}\text { its reputation as a safe financial } \\
\text { system. The FSC should be prepared } \\
\text { to use its powers to prevent } \\
\text { upstreaming of liquidity and to impose } \\
\text { 'net due' positions on branches, in } \\
\text { order to protect local depositors. Should } \\
\text { the jurisdiction's banking system } \\
\text { develop further (which is not currently in } \\
\text { the plans) and should it become } \\
\text { engaged with the global financial } \\
\text { activity of asset management or captive } \\
\text { insurance, there would be greater } \\
\text { concern. }\end{array}$ \\
&
\end{tabular}

Table 2. British Virgin Islands: Key Recommendations

\begin{tabular}{|c|}
\hline Recommendations \\
\hline High Priority \\
\hline Prompt and full implementation of the Regulatory Code, for all sectors. \\
\hline Prompt and full implementation of the new Securities Investment Business Act. \\
\hline Provide additional resources for on-site review of corporate and trust service providers. \\
\hline Increase the fine amounts contained in financial laws. \\
\hline Medium Priority \\
\hline $\begin{array}{l}\text { Shorten filing and publication periods for financial statements for all entities from six months to } 90- \\
120 \text { days. }\end{array}$ \\
\hline Enhance transparency of enforcement actions by requiring publication of enforcement decisions. \\
\hline $\begin{array}{l}\text { Require public disclosure of reasons for removal of FSC Board members, including the managing } \\
\text { director. }\end{array}$ \\
\hline Develop a crisis management plan for the jurisdiction focused on the local banking system. \\
\hline $\begin{array}{l}\text { FSC should include a discussion of financial stability issues as part of regular reporting to } \\
\text { government. }\end{array}$ \\
\hline $\begin{array}{l}\text { Develop a plan to put human resources in place to respond to new market intermediary business } \\
\text { models under SIBA, should the demand arise. }\end{array}$ \\
\hline $\begin{array}{l}\text { Develop a centralized, automated tracking system to follow up on recommendations made during } \\
\text { inspections. }\end{array}$ \\
\hline
\end{tabular}




\section{INTRODUCTION}

\section{A. Purpose of the FSAP Update}

\section{Developments in the financial sector and regulatory framework warrant an} update of the assessment conducted under the Fund's OFC program and finalized in 2004. Furthermore, the integration of the OFC program into the FSAP (Executive Board meeting 08/48 on May 30, 2008) has widened the scope of the assessment to include stability-related issues and stress tests of certain sectors. This report therefore covers both regulation and supervision, and matters relating to the soundness of the financial system and its ability to cope with stress. ${ }^{1}$ A separately conducted assessment of the AML/CFT framework is incorporated into these findings. ${ }^{2}$

\section{B. Context}

2. The BVI is a British overseas territory. It is governed by an elected parliament headed by a premier and a formal Cabinet. The government of the territory is fully responsible for all domestic laws and law enforcement, and raises its own revenue. A governor represents the British Crown for an appointed term but does not actively participate in day-to-day governance.

3. The territory is a small but prosperous jurisdiction. Government revenues are heavily dependent on the two main industries, tourism and financial services, with greater than 60 percent coming from FSC annual fees. The recent global financial crisis has not affected the health of BVI financial institutions, but it has caused growth of financial services to slow down, since the core business is company registration rather than asset management or banking. Incorporations were down slightly, but revenue remains fairly steady. The BVI tourism sector is intimately connected to the health of the U.S. economy and tourism revenue has been affected by the recession in the United States.

\footnotetext{
${ }^{1}$ Stress testing of the banking system was not undertaken, given the very small size of the sector, the lack of connection of the banking system to systemic vulnerabilities, and the limited resources of the mission.

2 The assessment was undertaken by the Caribbean Financial Action Task Force (CFATF) and the ROSC, attached to this report, was prepared by CFATF and reviewed by the IMF Legal Department.
} 
4. The BVI enjoys a high standard of living, particularly in comparison to the region. GDP is estimated at $\$ 1.095$ billion $^{3}$ or $\$ 38,818$ per capita (with a population of about $24,000) .{ }^{4}$ Unemployment remains low at 3 percent to 4 percent. The workforce is dominated by expatriate labor ( 65 percent of the total workforce, with expatriates filling an estimated 80 percent of financial services jobs).

Table 3. British Virgin Islands: FSC Revenue to Total Government Revenue (In thousands of U.S. dollars $)^{5}$

\begin{tabular}{lcrrrr}
\hline & 2005 & 2006 & 2007 & 2008 & \multicolumn{1}{c}{2009} \\
\hline FSC fees & $131,923.709$ & $144,053.668$ & $159,587.993$ & $164,896.132$ & $166,845.762$ \\
Total revenues & $234,269.183$ & $247,796.679$ & $275,672.198$ & $278,580.223$ & $268,644.091$ \\
Percentage & 56 & 58 & 58 & 59 & 62 \\
\hline
\end{tabular}

Source: FSC.

5. The BVI's fiscal health is deteriorating and the territory is undergoing budget rebalancing. Growth in expenditures has exceeded growth in revenues for the past several years and the flattening of revenue has meant that BVI was in a deficit position in 2009. The United Kingdom imposes fiscal restrictions on overseas territories, including a requirement to have 90 days liquidity in reserves. The BVI has breached this target and, as a consequence, cannot take on any additional debt without the permission of the United Kingdom.

\section{Generating revenue growth is the challenge of the future-it is clear that} financial sector growth has slowed as the corporate registration business may have matured. Further growth in this sector must come from value-added services. There is an ongoing discussion in the jurisdiction as to what value-added services can be developed as a complement to registration. The heavy reliance on revenue from the financial sector makes the fiscal position vulnerable to loss of business to competitors and the authorities are under pressure to ensure the regulatory framework does not make the BVI uncompetitive. Government and industry are coordinating to seek new markets, for example, in the BRIC

\footnotetext{
${ }^{3}$ The currency of the BVI is the U.S. dollar.

${ }^{4}$ Data from BVI ministry of finance.

${ }^{5}$ FSC data.
} 
jurisdictions; and the jurisdictions have consistently expanded the legislative framework to provide more product variety to clients.

7. The BVI is an important global financial services center because of its role in the registration of corporations and trusts. The BVI is also the second largest global domicile for investment funds. The mainstay of the sector is the incorporation of corporations or trusts that are financial holding companies, asset management companies, captive insurers, and the like. For the most part, these entities are set up in the BVI and subject to BVI law, but conduct all of their business (and hold all of their assets) elsewhere. The asset holdings of BVI incorporated companies are estimated to be US\$615 billion. ${ }^{6}$ While the BVI does not have direct linkages to other financial capitals via cash flows, it is linked through the corporations and trusts that have made the BVI the first port of call for those setting up offshore businesses. The BVI's ability to create and implement standards for incorporation and anti money-laundering and terrorist financing activities, and its ability to share information and cooperate with other authorities, is therefore crucial.

8. The future for offshore financial services is unclear. BVI has attracted business because of its tax neutrality (there are no corporate income or transaction taxes) and because of its legal infrastructure and modern regulatory framework. Changes to tax rules in onshore jurisdictions, such as in the United States where authorities have worked to make offshore transactions taxable onshore, will challenge offshore jurisdictions in general, as will changes to regulatory treatment of offshore vehicles, such as the proposed EU hedge-fund legislation. However, the future of offshores, and BVI in particular, remains to be decided. The recent Foot report examined the strengths and weaknesses of the British offshore financial centers and raised concerns regarding the lack of diversification in economies, but with no firm conclusions on the way forward. ${ }^{7}$

\section{The 2004 OFC mission found a number of weaknesses in the implementation of} regulation and made recommendations for increased on-site inspection capacity. The FSC has worked steadily to address these recommendations and now has a comprehensive inspections program in place, as noted below. The 2004 report also noted a number of shortcomings in the legislative framework, which have been addressed (although significant portions of this legislative change were done only in 2010).

\footnotetext{
${ }^{6}$ IMF staff estimates for 2008. By this measure, the BVI has a larger offshore sector than all other offshore centers, except for the Cayman Islands. However, as noted, while the holders of the assets reside in the BVI, the assets themselves are elsewhere.

${ }^{7}$ Michael Foot "Final Report of the Independent Review of the British Offshore Financial Centres," October 2009 http://www.hm-treasury.gov.uk/indreview brit_offshore fin_centres.htm. The report focused on the offshore centers with significant financial flows and therefore made relatively few direct comments on the BVI.
} 


\section{REGULATORY AND SUPERVISORY SYSTEM}

\section{Legal framework}

\section{The Financial Services Commission (FSC) is an independent supervisory} authority with broad powers to regulate the full scope of financial services offered from or in the BVI. The Financial Services Commission Act (FSCA), which came into effect in January 2002, established the FSC as an independent statutory body. The FSC has been given broad powers by statute to regulate, supervise, and enforce financial services activities carried on in or from the jurisdiction. These services include insurance; banking; insolvency; fiduciary business; money services business; company management; mutual funds business as well as the registration of companies; limited partnerships; and intellectual property. The FSC also has responsibility for overseeing compliance of companies and limited partnerships with the corporate or partnerships legislation. The FSCA provides the FSC with a wide array of specific regulatory, supervisory, and enforcement powers. These include the powers to issue binding guidance, apply terms and conditions to licenses and take a range of enforcement actions.

\section{Table. 4. British Virgin Islands: Structure of the Financial Sector-Current}

\begin{tabular}{lr} 
Number of banks (general license) & 6 \\
Number of banks (restricted license) & $11 /$ \\
Number of captive insurers & 287 \\
Number of insurance managers & 16 \\
Number of fund managers and administrators & 573 \\
Number of funds & 2,937 \\
Number of registered agents & 125 \\
Number of international business corporations (on register) & $448,1562 /$ \\
\hline
\end{tabular}

1/ An additional two banks are in the process of winding up.

2/ In addition, an almost equal number of entities have been formed under the legislation, but have since been struck off the register (for inactivity or violations of rules). Sometimes, these figures are aggregated and estimates of 800,000 BVI corporations are made. However, the more accurate number is the number of registered corporations as included here.

11. Since the last assessment, the FSC's statutory authority has been expanded. The FSC now has authority to take action against unlicensed persons carrying on financial services business; remove officers and directors of licensees if they are not fit and proper; impose monetary penalties where criminal action is not taken; and require regulated persons to provide information returns to the FSC. The independent Appeals Board created by the 
Financial Services Commission Act (FSCA) is now fully operational. This Board has jurisdiction to consider appeals of any FSC decision, except the refusal to grant a license.

12. In order to provide a more flexible regime that can be adapted quickly to market developments, the FSC has been given the statutory authority to issue legally binding codes. The Regulatory Code that was enacted in December 2009 provides critical detail of the regulatory requirements in several areas of general application to all licensees, including: licensing processes; fit-and-proper criteria; the licensee's corporate governance framework; and expectations for areas such as risk management, internal controls, internal audit, and record keeping. It also outlines requirements relating to financial reporting and auditors; outsourcing; segregation; protection of customer assets and capital; and insurance requirements.

13. Effective implementation of the Regulatory Code requires further action by the FSC. As of March 31, 2010, most of the sections of the Regulatory Code were in force. However, it is not clear to the mission team that the FSC had effectively ensured that firms have put in place the necessary arrangements to comply fully with the Code's provisions. Further, it must be amended to add a new part to address investment businesses, as the relevant parts ${ }^{8}$ of the new Securities and Investment Business Act, 2010 (SIBA) came into force in May 2010. There appeared to be confusion regarding full implementation of the Code; the FSC should assess its communication internally and with industry, and ensure there is a shared understanding of when compliance with these new rules is expected.

\section{Regulator}

\section{Governance}

14. The Board of Commissioners is the governing body of the FSC. It is made up of six commissioners plus the managing director (MD), who is an ex officio member. Commissioners are appointed by the Cabinet for a period not exceeding three years on terms set by the Cabinet. The FSCA provides that the Cabinet may only remove a Board member for cause and, as recommended by the previous assessment, it must now give written reasons for such removal. The statute does not require that these reasons be made public. Both the independence and the accountability of the Board would be enhanced by requiring that the reasons for any termination of a Board member be disclosed publicly.

\section{The MD is the chief executive of the FSC and is generally responsible for the} operations of the FSC. The Board may remove the MD as permitted by his contract of employment and the Board must give written reasons for any such removal. Neither the

\footnotetext{
${ }^{8}$ The Act was proclaimed in force on May 17, 2010, save for Part II, which deals with public issues of securities other than by mutual funds. The full operation of certain other provisions is subject to transition periods.
} 
terms of the MD's contract nor the reasons for dismissal are required to be made public. The independence and accountability of the MD would be enhanced if the permissible reasons for his termination under his contract were transparent and if the Board were required to disclose publicly the reasons for any termination of the MD.

16. The FSC consults extensively with industry on regulatory matters and several consultative committees and liaison groups have been formed to facilitate this process. The MD holds quarterly round-table meetings with the heads of all of the industry associations. The FSC also holds a quarterly "Meet the Regulator" town hall-style meeting, open to the public.

Table 5. British Virgin Islands: FSC Annual Staff Count

\begin{tabular}{|c|c|c|c|c|c|c|c|}
\hline \multirow[b]{2}{*}{ Division } & \multicolumn{7}{|c|}{ Total No. of Employees } \\
\hline & 2004 & 2005 & 2006 & 2007 & 2008 & 2009 & 2009 \\
\hline & & & & & & & Percentage \\
\hline Banking \& fiduciary services & 9 & 8 & 8 & 9 & 12 & 14 & 10.8 \\
\hline Insolvency & 5 & 5 & 5 & 5 & 5 & 5 & 3.8 \\
\hline Investment business & 9 & 9 & 9 & 10 & 12 & 12 & 9.2 \\
\hline Insurance & 4 & 8 & 8 & 8 & 9 & 9 & 6.9 \\
\hline Legal \& enforcement & 4 & 5 & 4 & 6 & 7 & 8 & 6.2 \\
\hline Policy, research \& statistics & 2 & 3 & 2 & 5 & 5 & 4 & 3.1 \\
\hline Registry of corporate affairs & 51 & 54 & 59 & 56 & 52 & 48 & 36.9 \\
\hline Corporate services & 13 & 19 & 23 & 24 & 24 & 26 & 20.0 \\
\hline Human resources and MDO & 5 & 5 & 5 & 5 & 5 & 4 & 3.1 \\
\hline Shipping registry $1 /$ & 4 & 4 & 4 & 4 & 0 & 0 & 0.0 \\
\hline Total & 106 & 120 & 127 & 132 & 131 & 130 & 100 \\
\hline
\end{tabular}

Source: FSC.

1/ Ceased to be FSC function in 2006 , but staff seconded to Registry for period thereafter.

\section{Budget and staffing}

17. The primary source of funding for the FSC is fees from company registrations and licenses of financial services firms. The FSCA permits it to keep a percentage of these fees-from 7.5 percent to 15 percent - as negotiated on an annual basis with the Cabinet. There appear to be no impediments to funding extra resources as necessary. In the MD's view, the funding provided to the FSC is sufficient to meet its present needs.

18. Significant resources are devoted to training. In recent years more than $\$ 3,000$ per staff member has been budgeted for training, and industry participants commented favorably on the expertise of most senior staff. However, it may be appropriate to focus additional 
efforts on ensuring junior staff develop a better understanding of the industry and markets they regulate.

\section{Accountability}

19. The FSC is accountable to the Cabinet and to the legislature. The budget and work plan of the FSC are approved by the Cabinet and then presented to the legislature. The MD also meets with the minister of finance monthly to report on general matters and on progress regarding the work plan. The FSC can appear before Select Committees of the House of Assembly when requested, and have done so. The annual report, including the financial statements, is provided to the Cabinet and is to be tabled with the legislature. The FSC's practice is to publish its annual report on its website.

\section{Supervision}

20. There is detailed and well executed, off-site review and an on-site inspection system designed to mitigate operational and reputational risks. A regulatory inspection tool developed by KPMG-KReview - is currently used by the Banking and Fiduciary Services Division and Insurance Division. KReview represents a range of automated supervisory support tools to assist the FSC staff to undertake an effective and detailed on-site inspection. A centralized and automated system to follow up on inspection recommendations should also be developed.

21. The on-site inspection process began in 2004 for most Divisions. Inspections commenced in 2008 for the Investment Business Division. All the Divisions are now fully engaged in regular inspections. The number of inspections completed by each Division since 2004 is set out below. Given the size and importance of the corporate and trust service provider sector, a greater number of inspections might be undertaken.

22. The authority of the FSC to collect information relating to the financial industry in general and of licensees in particular has been enhanced in the law. Quarterly prudential returns are required of banks. Mutual funds are required to file annual returns providing information on fund service providers; summary statements of financial position; investment strategy and listing status; asset allocations; and expenses. Annual audited statements for all regulated entities must be filed within six months of year-end, which is not in keeping with international practice of 90-120 days. The filing period should be shortened accordingly.

\section{Enforcement}

23. The FSC has a specialized enforcement function, which carries out investigations and brings actions before the Enforcement Committee. The FSC has wide enforcement powers and can issue cease-and-desist orders and directives, suspend or revoke licenses, and remove directors. The FSC can also apply to a court for a protection order against both 
licensees and unlicensed persons carrying on financial services business. A protection order could allow the FSC to freeze assets and appoint an administrator to take over the business among other actions.

Table 6. British Virgin Islands: On-site Inspections Conducted by FSC Regulatory Divisions

\begin{tabular}{lrrrrrr}
\hline & \multicolumn{6}{c}{ Year } \\
\cline { 2 - 7 } Division & 2004 & 2005 & 2006 & 2007 & 2008 & 2009 \\
\hline $\begin{array}{l}\text { Banking and trust and corporate service } \\
\text { providers }\end{array}$ & 5 & 5 & 12 & 14 & 30 & 19 \\
Insolvency & 0 & 0 & 0 & 2 & 6 & 3 \\
Investment business & 0 & 0 & 0 & 0 & 4 & 9 \\
Insurance & 0 & 13 & 16 & 13 & 13 & 6 \\
Total & $\mathbf{5}$ & $\mathbf{1 8}$ & $\mathbf{2 8}$ & $\mathbf{2 9}$ & $\mathbf{5 3}$ & $\mathbf{3 7}$ \\
\hline
\end{tabular}

Source: FSC.

24. The enforcement work of the FSC has also been intensifying, with growing numbers of enforcement actions, from 4 in 2005 up to 60 in 2009. The Enforcement Division also does surveillance of the industry, using information services and by scanning financial publications. With increased examinations, the enforcement area may be able to target the more serious breaches. Recent actions have demonstrated that the FSC has both the willingness and ability to address high profile and sensitive issues.

25. Fine levels for major breaches are relatively low and may not have a sufficient deterrent effect. Increasing the level of fines available to the FSC is recommended. Administrative penalties for the same offences should rise proportionately.

26. The decisions of the Enforcement Committee are not required to be made public. Additional transparency would engender a greater understanding of FSC policy through the community and apply an additional discipline to the market place. Decisions are appealed to the Financial Services Appeal Board, the members of which are appointed by the Cabinet. 


\section{A. Banking Sector}

27. The banking system of the BVI has \$2.5 billion in assets and banks range in size from $\$ 98$ to $\$ 915$ million. ${ }^{9}$ The system is comprised of three branches; three subsidiaries of foreign banks; and one government-owned domestic bank. The banks engage in traditional banking business; lending; deposit-taking; and simple off-balance-sheet activities, such as providing letters of credit. Entry into the system is subject to strict licensing standards that require the applicant be a highly-rated institution from a jurisdiction that exercises consolidated supervision. While there have been changes in ownership, a new banking license has not been issued in the past 20 years. The only license issued was in 2006, when the government-owned bank converted from a development bank to a commercial bank.

28. BVI law provides for three classes of banking license: a general banking license, a restricted Class I banking license, and a restricted Class II banking license. A general banking license permits the holder to conduct banking business within and outside the BVI. A restricted Class I license and a restricted Class II license do not allow the respective holders to take deposits or make loans to BVI residents except in the case of corporations. (The difference between a Class I and Class II license relates to the manner in which they can deal with BVI corporations.) There are six general banking licenses, one restricted Class I license and no restricted Class II licenses.

29. The well-developed legal and regulatory framework and a detailed inspections program are reinforced by consolidated regulation of parent banks. The BCP review shows a major improvement from the 2004 report. Given that the system is 96 percent foreign owned, it benefits from the parent/head office systems and expertise that enable the institutions to meet international standards established by the BVI. The foreign ownership also requires the FSC to have strong cross-border collaboration with the home-country supervisor and needs to review systems developed at the parent company for global application, and determine their applicability and adequacy for the BVI branch or subsidiary.

\section{B. Insurance Sector}

30. The BVI insurance industry is dominated by captive insurers, the majority of which are single-parent captives with parents in the United States. There are currently 287 captive insurers registered in the BVI. In recent years, the FSC has seen a relatively large number of exits from the industry, including shutting down inactive or noncompliant firms. The growth of the industry has slowed and it is unclear where the future lies. While there is an increase in the number of captives from outside the United States, the BVI faces competition from a number of jurisdictions, both offshore or from onshore jurisdictions.

\footnotetext{
${ }^{9}$ The BVI is not an offshore banking center, which are almost entirely onshore assets.
} 
There are some small general and life insurance companies, subsidiaries of large multinational companies, which serve the local population.

31. Both insurance managers and captive insurers are subject to licensing as set out in legislation, particularly the Regulatory Code. In particular, they must meet the fit-andproper criteria as applied to all supervised entities, for example, those relating to the suitability of directors and shareholders. All captive insurers must appoint an insurance manager, which is subject to qualification requirements and books and records requirements.

32. Insurance managers play a key role in monitoring captives. Section 51 of the Insurance Act places an obligation on the insurance manager to report immediately to the Commission any information relating to the affairs of the licensed insurer that it has obtained in the course of acting as the insurer's manager which, in the insurer's manager's opinion, suggests insolvency, criminal activity, serious breach of the Insurance Act, Regulatory Code or any other enactment or guidelines or codes relating to AML/CFT, default in payments of liabilities or failure to conduct business in accordance with sound insurance principles.

33. Insurance managers and the insurers they manage are subject to the FSC on-site inspection regime. The purpose of these inspections is two-fold: an inspection of the insurance manager itself and an inspection of the captive insurers that it manages.

34. The shortcomings noted in the $\mathbf{2 0 0 4}$ report have largely been addressed. Insurance managers and captive insurers are subject to governance and internal control requirements under the Insurance Act and Regulatory Code. As noted, the on-site program has developed significantly since the 2004 report. There are a number of changes to come, particularly with reference to the recently enacted Regulatory Code.

\section{Investment Business}

35. At the present time, the principal securities activity in BVI is the incorporation and authorization of mutual funds. At the end of December 2009, there were a total of 2,937 active mutual funds registered or recognized in the BVI, down just slightly from 2,953 at the end of 2008. This is an increase of 23.8 percent over the past five years. Only 7.4 percent of the funds authorized by the FSC are public mutual funds that may be sold by prospectus to any investor. The rest are either professional funds (sold to sophisticated purchasers only) or private funds, where offers to the public are prohibited and the number of investors must be fewer than 50. In practice, even the public funds do not make their securities available for purchase in the jurisdiction.

36. The Mutual Funds Act provided for the registration of public mutual funds and the recognition of private and professional funds. It also governs the licensing of mutual fund managers and mutual fund administrators operating in or from the BVI. This has been supplemented by the enactment of the legally enforceable Regulatory Code, effective in 
2010. The Regulatory Code includes requirements of application to all types of licensees, along with detailed sector-specific rules.

37. On the first day of the mission, SIBA was passed by the legislature and the greater part of the legislation came into force in May 2010. SIBA expands the categories of investment activities subject to licensing: introduces requirements for the public issue of securities (other than by mutual funds); codifies and modernizes the regulation of mutual funds and their service providers; recognizes accounting and auditing standards; requires audited financial statements to be prepared by approved auditors; and addresses market abuse offences. SIBA and a package of related subsidiary instruments (Mutual Fund Regulations and the Public Funds Code) were reviewed. The FSCA and now SIBA provide the main legal framework for the supervision of securities activities in the BVI.

38. The FSC licenses mutual fund administrators and managers operating in or from the jurisdiction. As of the end of 2009, 573 licenses had been granted. Mutual funds authorized by the FSC are not required to have managers or administrators that are licensed in the jurisdiction and very few of these licensees are resident. SIBA gives the FSC authority to regulate other market participants such as brokers, dealers and underwriters.

39. Most of the areas requiring improvement identified in the previous assessment will be addressed with the full implementation of the investment business sections of the Regulatory Code, SIBA, and various subsidiary instruments. But, until all of those instruments are fully effective, the only recommendations that can be considered fully implemented are those with respect to on-site inspections and additional enforcement resources. Without the full and effective implementation of the new regime, the jurisdiction continues to be only partially implemented with respect to the IOSCO Principles relating to collective investment schemes (mutual funds).

40. Priority should be given to prompt and full implementation of the Regulatory Code and the new SIBA regime. The Regulatory Code was enacted at the end of 2009 and SIBA has only recently come into force. Certain key parts of the new regime, such as the Public Funds Code, are not yet final. Also, full implementation includes being seen to be actively enforcing the new requirements on the marketplace. As there are no securities intermediation activities being carried on at present, this gap may not be serious. Full implementation of the regime for intermediaries, such as brokers or dealers, requires new regulations and amendments to the Regulatory Code. Representatives of industry have indicated that there may be interest from market participants for licensing under one or more of these categories fairly soon, so the need to draft and implement the necessary instruments may become pressing in the near term.

41. There continue to be areas where improvements are required, particularly with respect to continuous disclosure obligations of public mutual funds. The requirement for public disclosure of material changes should be timelier; 14 days to amend a prospectus may 
be acceptable, but notice of the change should be published promptly. Further, the deadline for filing and publishing audited financial statements should be shortened; the current requirement to file six months after year-end is two to three months longer than is mandated in major jurisdictions.

Table 7. British Virgin Islands: Number of Active Mutual Funds by Category

(As at December 31)

\begin{tabular}{|c|c|c|c|c|c|c|c|}
\hline \multirow[b]{2}{*}{ Category } & \multirow[b]{2}{*}{2005} & \multirow[b]{2}{*}{2006} & \multirow[b]{2}{*}{2007} & \multirow[b]{2}{*}{2008} & \multirow[b]{2}{*}{2009} & \multicolumn{2}{|c|}{2009} \\
\hline & & & & & & $\begin{array}{c}\% \text { of } \\
\text { Total } \\
\text { Funds } \\
\end{array}$ & $\begin{array}{c}\% \\
\text { Increase } \\
2005-09\end{array}$ \\
\hline Professional mutual funds & 1,376 & 1,530 & 1,694 & 1,894 & 1,905 & 64.9 & 38.4 \\
\hline Private mutual funds & 799 & 832 & 815 & 831 & 816 & 27.8 & 2.1 \\
\hline Public mutual funds & 197 & 209 & 222 & 228 & 216 & 7.4 & 9.6 \\
\hline Total & 2,372 & 2,571 & 2,731 & 2,953 & 2,937 & & 23.8 \\
\hline
\end{tabular}

Source: FSC.

Table 8. British Virgin Islands: Number of Active Fund Managers and Administrators, by Category

(As at December 31)

\begin{tabular}{lrrrrrrr}
\hline & & & & & & \multicolumn{2}{c}{$\begin{array}{c}\% \\
\text { Increase }\end{array}$} \\
& \multicolumn{1}{c}{ Category } & 2005 & 2006 & 2007 & 2008 & 2009 & 2005-09 \\
\hline Management services & 428 & 455 & 467 & 496 & 491 & 4.7 \\
$\begin{array}{l}\text { Management and administrative } \\
\text { services }\end{array}$ & 50 & 49 & 46 & 46 & 45 & $(10.0)$ \\
Administrative services & 36 & 37 & 36 & 39 & 37 & 2.8 \\
Total & $\mathbf{5 1 4}$ & $\mathbf{5 4 1}$ & $\mathbf{5 4 9}$ & $\mathbf{5 8 1}$ & $\mathbf{5 7 3}$ & $\mathbf{1 1 . 5}$ \\
\hline
\end{tabular}

Source: FSC.

\section{Trust and Corporate Service Providers}

42. The incorporation of BVI business companies and the provision of trust and corporate services is the central business of the financial sector in BVI. Trust and corporate services have been recognized internationally as a potential source of financial risk, including risks from money laundering and the financing of terrorism. As these corporations 
and trusts in the main do not deal with the assets of BVIslanders, these activities do not pose a direct risk of financial losses to citizens in the same way as, say, the onshore banking sector. However, this sector (particularly as a result of its magnitude and prominence within the BVI financial sector) also constitutes a major source of reputational risk.

\section{The trust and corporate service providers (TCSP) industry in the BVI is} currently comprised of $\mathbf{1 2 5}$ firms offering a mixture of services. A common feature of these firms is their roles as Registered Agents under the BCA. Under the Act, every business company incorporated under the Act requires a Registered Agent (RA) ${ }^{10}$ to administer its affairs at all times. RAs may be licensed under one of two statutes, namely the Banks and Trust Companies Act (BTCA) or the Company Management Act (CMA). Licensing under either the BTCA or the CMA grants the practitioner the right to act as Registered Agents for business companies.

44. An RA carries out a number of functions. These include maintaining the registered office of the company and its memorandum and articles of association, and maintaining a register of shareholders and directors.

45. Trust business is governed by the BTCA. The Act provides that no trust business may be conducted from within the BVI (whether such business is within or outside the BVI), unless the person conducting this business holds a license under the BTCA. The holder of a Class I trust license is entitled to carry out both trust work and company management work.

\section{Licensing under the CMA entitles the holder to offer company management} services. These services include: the formation of companies, including the continuation of companies as BVI companies; the provision of registered agent services; the provision of registered office services; and the provision of directors or officers for companies, whether such companies are incorporated or registered in a jurisdiction outside the BVI; and the provision of nominee shareholders in companies, whether such companies are incorporated or registered in a jurisdiction outside the BVI.

47. Registered Agents are considered fiduciaries. RAs are under a duty (particularly in the case of Trust Companies) to ensure that the interests of their clients are protected. ${ }^{11}$ In the case of trust and corporate service providers (TCSPs), their duties may not be strictly fiduciary in nature, depending on the services provided (save for such fiduciary duties that may be owed as directors and officers); however, they are placed under a heavy burden under legislation.

\footnotetext{
${ }^{10}$ Section 91 of the BCA.

${ }^{11}$ The VISTA law seeks to overcome some of the common-law rules relating to trustees by actually restricting the role of such trustees in these specific trusts as regards their powers to intervene in the management of companies whose shares are held by those trusts.
} 
48. The RA regime is predicated on placing a high regulatory burden on RAs to essentially ensure the compliance of their clients to the relevant laws in the BVI. This is in addition to the RA's own obligations under the governing and AML/CFT legislation to carry out such critical obligations, such as know-your-customer requirements; suspicious transaction reporting; and record-keeping. Because the vast majority of the actual business of the corporations takes place abroad, the RA may find obtaining the relevant information from the business owners and directors on the ultimate beneficial owners; the nature of the business; the relevant transactions; and the changes in the owners and directors of the business a challenge. RAs may be under pressure from corporations for documentation and certificates of good standing. In order to combat these challenges, RAs generally maintain stringent policies relating to the acceptance of business as well as policies for the termination of business relations (including resignations) where they are unable to get the appropriate level of information from companies. They are required by law to serve on the company and file with the Registry both notice of their intention to resign as well as notice of their actual resignation.

49. Since the last assessment, under the OFC program, there have been significant changes to the legal and institutional framework in this sector. The overarching legislative framework for the TCSP industry is comprehensive and in keeping with the OGBS Statement of Best Practice. However, the Regulatory Code is not being fully enforced at this time because of pending amendments and the need to provide licensees with time for effecting compliance. Also, the penalties for the commission of offences under the CMA and the BTCA (especially, as regards the conduct of unauthorized business) appear to be low.

50. The FSC monitors RA compliance with rules using a variety of methods, including the receipt and analysis of data from licensees and by the conduct of off-site examinations. The FSC uses a risk-based approach in devising its examination program. The Banking and Fiduciary Services Division carried out 19 inspections for the TCSP sector in 2009 , using a core inspection staff of four individuals. The frequency of inspections appears low (although the quality of the examinations appears high), given the size of the regulated population and the importance of the sector to the governments revenues. It is recommended that the authorities consider increasing the FSC's complement of examiners in this area.

51. The BVI authorities have also implemented a regime for the immobilization of

bearer shares. Companies with bearer shares are required to deposit these shares with either a Recognized Custodian (being a recognized securities exchange or clearing organization) or an Authorized Custodian approved by the Commission pursuant to the FSCA. The FSC must be satisfied of the fitness of the person to be an Authorized Custodian of bearer shares as well as the systems in place for the secure custody of the shares and to comply with the procedures prescribed in the BCA. 
52. "Grandfathered" bearer shares (those issued by companies authorized prior to the change in law) that have not been deposited with either type of Custodian are deemed by operation of law to be disabled. Thus, all rights attached to such shares are suspended. Companies that wish to reactivate the rights attached to these shares must apply to the court for an extension of time to deposit bearer shares with a recognized or authorized custodian.

\section{E. International Information Sharing and Cooperation}

53. The FSC has demonstrated both its willingness and ability to be a full partner in international information sharing and cooperation. ${ }^{12}$ There are no legal impediments to information sharing either domestically or internationally. Financial Services (International Cooperation) Act, 2000 (FSICA), which set out requirements for information sharing with foreign regulators and foreign law enforcement agencies, was repealed in 2006. The FSCA was amended to incorporate information-sharing provisions that expanded and clarified the FSC's authority in response to concerns raised during discussion of international cooperation initiatives and the process of negotiating to become a signatory to the IOSCO Multilateral Memorandum of Understanding Concerning Consultation and Cooperation and the Exchange of Information (IOSCO MMOU). The FSC has become a full-signatory to the IOSCO MMOU.

54. The FSC actively participates in regional and international cooperation. It is a member of the Offshore Group of Banking Supervisors, the Caribbean Group of Banking Supervisors and the Association of Supervisors of Banks of the Americas. The FSC attends regulatory colleges for two Canadian banking groups and has a Memorandum of Understanding (MOU) with the Office of the Superintendent of Financial Institutions (OSFI). There are no regulatory colleges for the U. S. banking groups in the jurisdiction, but the FSC has an MOU with the regulator in Puerto Rico and is negotiating an MOU with the U. S. supervisors. The FSC holds regular meetings with the head offices of these banks in Puerto Rico. The FSC also has an MOU with Jersey.

\footnotetext{
12 The BVI has also worked to cooperate on taxation matters. In August 2009, it joined the OECD's "white list" of countries which have substantially implemented internationally agreed tax standards.
} 
Table 9. British Virgin Islands: Information Sharing under the IOSCO MMOU

\begin{tabular}{rrrrr}
\hline Year & $\begin{array}{c}\text { Requests Made } \\
\text { to the FSC }\end{array}$ & $\begin{array}{c}\text { Average } \\
\text { Response Time } \\
\text { (Days) }\end{array}$ & $\begin{array}{c}\text { Requests } \\
\text { Made by the } \\
\text { FSC }\end{array}$ & $\begin{array}{c}\text { Average Response } \\
\text { Time (Days) }\end{array}$ \\
\hline 2005 & 15 & 17.27 & & \\
2006 & 29 & 28.48 & & \\
& & & & 17.62 \\
2007 & 29 & 24.91 & 26 & 30.26 \\
2008 & 81 & 18.20 & 60 & 18 \\
2009 & 97 & 17.17 & 64 & \\
\hline
\end{tabular}

Source: FSC.

\section{F. Anti Money-Laundering and Combating the Financing of Terrorism}

55. An AML/CFT Mutual Evaluation Assessment was carried out by a team from the Caribbean Financial Action Task Force (CFATF) in 2008. The CFATF Report (November 2008) was incorporated into a ROSC, which is attached to this report.

56. The CFATF report found that the BVI has an AML/CFT system that is broadly in line with international standards. Money laundering and terrorist financing have been criminalized with some minor deficiencies cited. Specific deficiencies were identified in the areas of customer due diligence; the dissuasiveness of penalties; requirements for nonprofit organizations; and the adequacy of supervisory coverage. The authorities have undertaken steps to address all of these issues.

57. Supervisory resources devoted to AML/CFT matters require enhancement. The low number of ML prosecutions suggests a limited implementation of the legal framework. The authorities have added resources subsequent to the CFATF report with the aim of improving `supervision of compliance with AML/CFT standards for both financial institutions and designated nonfinancial businesses and professions. The report also noted that law enforcement resources may be insufficient, including an inadequate number of officers with in-depth training and experience in the area of financial crime. The authorities have since stepped up training in AML/CFT investigative techniques. 


\section{FinanCial Stability IsSUeS}

\section{A. Vulnerabilities of the Banking System ${ }^{13}$}

58. The BVI has been relatively insulated from global financial shocks to date, and has remained stable. The banking system is focused on domestic activity and was not directly exposed to volatile asset markets (e.g., structured credit). Revenues and profitability have remained relatively stable and the sector has been largely unaffected by the distresses of the wholesale markets.

59. BVI is highly unlikely to be an originator of a major systemic shock for the wider international markets. Losses at the branches and subsidiaries located in the BVI would be insufficient to impair the stability or soundness of the parent banks as the local presences are not significant within their respective group structures.

60. However, vulnerabilities exist. Only one bank, the government owned National Bank of the Virgin Islands, is locally owned and the remainder of the system is comprised of branches and subsidiaries of foreign banks. Therefore, distress experienced by the parent banking institutions would be likely to transmit and have adverse effects on the BVI branches and subsidiaries. Moreover, the BVI banking system is highly concentrated, with two branches having approximately half of the deposit and loan markets of territory.

\section{The banking sector appears highly liquid but there are aspects of liquidity risk} management to consider. The banking system is characterized, largely, by high volumes of liquidity, with surplus funds typically being lodged with the parent institutions. In a stressed situation, therefore, the majority of banks operating in the BVI would be reliant on access to liquidity from their parent institutions. However, there have been no requirements for the branches, subsidiaries or the nationally owned bank to identify contingency arrangements for alternative or diversified sources of funding or liquidity. Should there be a crisis in one of the banking parents there could be local contagion effects within the BVI.

62. The FSC monitors liquidity levels in the banks. Banks submit information quarterly. Liquidity remains very high (Table 10). The FSC closely monitors net liquidity due to/from parent banks and adjusts and limits these based on a risk assessment. The FSC also requires a capital equivalence deposit for branches that is equal to the required CAR for subsidiaries. The FSC maintains good communications with parent-bank regulators and intensified this contact during the recent crisis.

\footnotetext{
${ }^{13}$ Stress testing of the banking system was not undertaken by the mission due to the small size of the system and its lack of interconnectedness.
} 
Table 10. British Virgin Islands: Bank Liquidity (Aggregate)

(In millions of U.S. dollars, unless otherwise indicated)

\begin{tabular}{lrrrrr}
\hline & 2009 & 2008 & 2007 & 2006 & 2005 \\
\hline Liquid assets & 927,411 & 873,465 & $1,081,922$ & 644,741 & $1,231,407$ \\
$\begin{array}{l}\text { Liquid assets as a percentage of } \\
\text { assets }\end{array}$ & 25 & 29 & 33 & 30 & 31 \\
$\begin{array}{l}\text { Liquid assets as a percentage of } \\
\text { deposits }\end{array}$ & 36 & 46 & 49 & 41 & 41 \\
\hline
\end{tabular}

Source: FSC.

\section{Although the major threats to the BVI are external, there are some internal}

risks. As the authorities are well aware, reputational risk is the primary threat to the sustainability and any further development of the island's financial sector. An association of BVI with a major fraud or misconduct in any financial sector, but most particularly with respect to the trusts and corporations serviced on the island given the relative size of this industry, would be damaging for the BVI reputation and might lead to flight of business from the island. The authorities are conscious of this and are keen, among other actions, to identify any possibilities of cooperation with nondomestic authorities to track down fraudulent behavior or regulatory breaches.

64. There are potential risks from business development in the BVI. Neither the banking sector specifically or the financial sectors on the island more generally are heavily inter-connected or exposed. Hence, weakness in one institution, other than through reputational and contagion risks, would not necessarily undermine the financial system. The state-owned bank, although small and sufficiently capitalized for its current business, has expressed an interest in growth. As a priority, the skill and management deficits the FSC has identified at the bank need to be addressed. Were it to grow, it would require greater capital. Bank management would also need to demonstrate a depth of skill and ability concomitant with the size and complexity of any new business line.

\section{B. Crisis Management Framework}

65. No formal crisis management framework is in place. Formally, there are no policies and procedures in place to respond to a crisis situation. Although the BVI has been relatively insulated and the prospect of a severe crisis may be relatively low, there are some gaps in the present arrangements. The authorities do not have a fully articulated contingency plan were the banking or financial sector to come under pressure. There is no provision for emergency lending, and no contingent credit lines are in place. Indeed, the BVI government is suffering budgetary constraint and the BVI cannot increase its borrowing further without permission of the United Kingdom. Hence, were the BVI financial sector to come under 
pressure, then the government would have no recourse to reserves or contingent lines of credit. At the micro level, the FSC has not required contingency planning to be put into place in the banking institutions and there are no requirements for banks to ensure they have reserve committed (and tested) lines of credit or alternative funding should this become necessary.

66. However, the BVI arrangements exhibit a number of strengths. Structurally, many critical elements are already in place to develop a robust and proportionate crisis management framework. The FSC has the necessary legal gateways to communicate and exchange information with domestic and overseas authorities, not merely banking supervisors. Also, the FSC has broad general powers to intervene with institutions, including powers of direction and the removal of executives from failing institutions. The FSC could direct provisioning and could write down shareholder equity as necessitated.

\section{The BVI benefits in particular from the potential for flexibility and nimbleness} in its authorities' responses to emerging situations. This responsiveness was demonstrated in the crisis of 2008, when the authorities were proactive in their engagement with the banks at local and also parental level, seeking confirmation of financial soundness and willingness to provide parental support. Additionally at the request of the FSC the BVI banks issued a joint statement to the public outlining their position with respect to liquidity.

\section{Financial Stability Policy}

68. In the absence of a central bank or other institutional arrangements, the FSC plays a critical role in financial stability issues concerning the Territory. The FSC does not have an explicit mandate, but its core functions essentially comprise guardianship of financial stability. In this role, it is supported by government and there is close contact between the FSC and ministry of finance. However, there are no formal institutional arrangements in place for the regular coordination or oversight of the financial sector to be discussed with the ministry or government, for example, the Cabinet. The authorities have, in the context of the 2008 crisis, demonstrated their alertness and responsiveness to risks in developing situations and their ability to coordinate at short notice. Nonetheless, a longerterm potentially strategic view underpinned by more formalized regular coordination with government may broaden awareness of the strengths and risks of the financial sector beyond the FSC and the ministry of finance. A formal report on crisis management and financial stability as part of regular monthly and annual reporting to government is recommended as a means of increasing awareness of the issues.

69. FSC has begun to establish broader financial sector oversight mechanisms. In 2009 the FSC set up an internal Crisis Management Committee to assess the risk of spill-over effects from global financial turbulence into the BVI and across sectors. Increasingly, international good practice encourages macro prudential oversight, which the FSC has not yet focused upon. Given the establishment of the Crisis Committee in the FSC and the 
practice of quarterly data collection and analysis, semi-annual discussion is held with each bank (quarterly where conditions merit), substantial elements are in place to support a proportionate macro-prudential dimension for the financial sector.

70. The primary focus of the Crisis Committee is to ensure the reputational integrity of the jurisdiction, with particular emphasis on the company registration sector. The FSC has been keen to make other jurisdictions aware of its willingness to assist and cooperate in cases of concern. The Committee seeks to monitor BVI entities globally on a weekly basis, including whether any are involved in litigation, if so the nature of the litigation and whether they are under investigation or whether the FSC needs to act. The FSC is anxious to be aware or be notified of any suspicious activity by BVI institutions or of institutions falsely purporting to have BVI incorporation. The FSC is an associate member of the UK Financial Intelligence Network (UK FIN-NET).

71. Home-host regulatory relationships are essential. To a great extent, the FSC has pursued the policy that prevention is better than cure. The FSC has a cautious and restrictive approach with respect to licensing new banks and, indeed, banking guidelines have remained the same since 1984. Coupled with the relatively straightforward business lines adopted by the banks, this has ensured the BVI banking sector has stayed out of the direct path of the global financial crisis. Nonetheless, the majority of the banking sector has overseas parentage and exposure to the international groups presents a significant source of potential risk or instability for the BVI. In this context, the relationship between the FSC and the home state supervisors is a critical factor in the effective supervision of its domestic banking system.

72. But care is needed with respect to reliance on home regulators. Based on the size of the BVI operations, the FSC has little automatic leverage in cross-border supervisory relationships or colleges of supervisors. However, the FSC is aware of the need to make its presence felt and to develop supervisory relationships proactively, so that information flows and supervisory cooperation are not limited to, or purely defined by, written agreements. It has been thus far successful in establishing a regional reputation and enjoys positive relations with home regulators and its neighbors and this would be important to maintain. The FSC further supplements its ability to conduct group-wide analysis and risk assessment by requiring the BVI banks to submit the financial data of their parent group. This analytical discipline can and should reinforce and inform the cross-border supervisory relationships ensuring that the FSC is not restricted to being a passive recipient of information from the overseas consolidated supervisors.

\section{Alternative options available to the FSC to limit the exposure of its banking} sector to wider risks are limited but should be considered. The FSC needs to be ready and able to use its powers to prevent the up-streaming of deposits by the subsidiaries and branches in the BVI to their parent entities and to require branches to maintain net "due to head office" positions as soon as signs of pressure on parents or groups emerge. The FSC is 
already debating the merits of this policy with fellow supervisors in the form of the Caribbean Group of Banking Supervisors.

74. The FSC should ensure that contingency planning is put in place by the banks and reviewed regularly by the supervisor. Particular attention should be given to reviewing liquidity policies and ensuring that contingency liquidity arrangements are in place. This will not be easy, given the broad perception that the banks are highly liquid.

\section{A deposit compensation scheme (DCS) would be a welcome step to reinforce} systemic stability, and plans are underway. Industry, government, and the FSC all support plans to introduce a DCS and a project to establish a scheme has been initiated. So far, no details have been agreed; for example, the scale and scope of compensation $(\$ 50,000$ to $\$ 100,000$ is the range under discussion to date); the mechanism of funding; or the organization, management and location of the DCS. However, the ministry of finance has begun work using the Canadian model of DCS and Canadian legislation as a basis, although there are no plans to adopt the Canadian approach without modification for the BVI's needs. ${ }^{14}$ The timescale to introduce and pass the required legislation in the BVI is the end of 2010, which is highly ambitious, given the range of outstanding issues and the agreed need for industry consultation.

\footnotetext{
${ }^{14}$ The authorities are aware of the new International Association of Deposit Insurers (IADI) principles for deposit insurance and are working within international best practices.
} 


\section{ANNEX-ObSERVANCE OF FinANCIAL SUPERVISION STANDARDS AND CODES-SuMMARY} ASSESSMENTS

This Annex contains the summary assessments of standards and codes in the financial sector. The assessment has helped to identify the extent to which the supervisory and regulatory framework is adequate to address the potential risks and vulnerabilities in the financial system.

The following detailed assessments were undertaken:

- Basel Core Principles for Effective Banking Supervision-by Mr. Michael Deasy (Central Bank of Ireland) and Mr. José Tula (consultant)

- The FATF 40+9 Recommendations for AML/CFT - by a Caribbean Financial Action Task Force team comprised of Mrs. Hypolite-Bones, Central Bank of Trinidad, Ms. deVries, Central Bank of the Netherlands, Mrs. Edun-Watler, Cayman Islands Monetary Authority, Mr. Maxwell, Royal Barbados policy force, and Mr. Hernandez, CFAFT Secretariat and approved by Mr. Hagan, IMF LEG Department.

The BVI's compliance with the international supervisory standards is generally high, and most of the issues raised in the 2004 assessment have been addressed.

\section{A. Basel Core Principles for Effective Banking Supervision}

\section{The banking system in the BVI is small and focused on a limited range of local} services. The system has a total of $\$ 2.5$ billion in assets. Banking services are limited to deposit taking and direct lending (mortgages and consumer credit). There is no payment system and given the use of the US dollar in the jurisdiction, no connection to monetary operations. The system is dominated by branches and subsidiaries of foreign banks (mostly Canadian and Puerto Rican). There is one small local bank, which is government owned. Unlike other offshore financial centers, the authorities have taken the view that there the banking system should remain very limited and conservative.

\section{BVI has a solid legal basis for an effective banking supervisory regime,} particularly after the recent enactment of the Regulatory Code, 2009. The challenges facing the FSC lie in the implementation of the rules and regulations under this legislation. Although elements of the Regulatory Code were largely in place in the form of guidance, there are many additions bringing the framework into compliance with Basel II. While the FSC appears to have sufficient resources to oversee the current (limited) range of banking operations, it should keep resources, both in terms of numbers and expertise, under constant review, given the increased workload on foot of the new legislation and the increasing complexity of banking supervision. Should the jurisdiction make a decision to allow expansion of the range and size of the banking, there would be a need for additional resources. 


\section{Information and methodology used for assessment}

3. The legal structure for banking supervision is based on three principal enactments: Banks and Trust Companies Act, 1990, as amended; Financial Services Commission Act, 2001, as amended; and the Regulatory Code, 2009. The Regulatory Code, which is derived from the Financial Services Act, 2001 has full statutory backing. Between them, they provide the FSC with sufficient powers to implement an effective banking supervisory regime. This legislation is supported by the issue of guidance notes from time to time (e.g., on licensing policy).

4. The assessment was based on the above. It was also based on a self-assessment prepared by the FSC, together with responses to specific questions raised with the FSC in advance of the visit. During the assessment, the assessors met with all relevant staff in the FSC, representatives from the licensed banks, the Bankers Association, and representatives from the legal and accounting professions. They also met with representatives of the Financial Investigation Agency (FIA) to which reports of suspicious transactions relating to money laundering and terrorist financing are sent.

\section{Institutional and macroeconomic setting and market structure_overview}

5. BVI law provides for three classes of banking license: a general banking license, a restricted Class I banking license, and a restricted Class II banking license. A general banking license permits the holder to conduct banking business within and outside the BVI. A restricted Class I banking license and a restricted Class II banking license do not allow the respective holders to take deposits or make loans to BVI residents except in the case of corporations. (The difference between a Class I and Class II license relates to the manner in which they can deal with BVI corporations.)

\section{There are six general banking licenses, one Class I license and no Class II}

license. Two other Class I licenses have or are in the course of surrendering their licenses. Of the six general licenses, three are branches of overseas banks and three are locally incorporated. Of the three locally incorporated, two are subsidiaries of overseas banks and one is a BVI government owned bank.

7. The three branches are Banco Popular de Puerto Rico, First Bank Puerto Rico, and First Caribbean International Bank. The two subsidiary banks are Scotia Bank BVI Limited (Canada) and VP Bank (Liechtenstein). The government-owned bank, National Bank of the Virgin Islands Limited (NB), was formerly the Development Bank of the Virgin Islands. NB has been in existence for many years, but only came within the regulatory remit of the FSC since 2006, when it was issued a banking license and changed to its present name.

8. The Class I bank is London International Bank and Trust Limited. It operates a type of group treasury activity for its industrial parent group. It has no deposits and its entire share capital is invested with group companies. The two other Class I licensees in the process of winding down are Rathbone Bank (BVI) and Bank of East Asia (BVI) Limited (Hong Kong). The former is closing down following a strategic decision by the parent to close down 
all its offshore operations and the latter because it did not feel the need any more for a banking presence in the BVI.

9. The type of business undertaken by the banks is traditional and conservative (deposit-taking from and lending to BVI residents), although First Caribbean International Bank, Scotiabank, and VP Bank do have some interaction with the offshore activities conducted in the BVI.

10. The banking system in the BVI has been left untouched, relatively speaking, by the recent turmoil in the banking markets. All are well capitalized and all have been profitable in recent years. At end-December 2009, total assets for all the banks amounted to nearly $\$ 2.5$ billion, almost all of which related to the general banks. Total capital amounted to $\$ 402$ million and total pretax/post tax profits to $\$ 59$ million.

\section{As five of the six general license banks are branches or subsidiaries of major} banks, their banking systems, internal control systems, accounting standards, etc., are based on group practice.

12. The aggregate balance sheet size for the six operational banks amounts to $\$ 2.5$ billion. There is little or no off-balance sheet activity. Of the figure of $\$ 2.5$ billion, $\$ 1.5$ billion relates to the assets/liabilities of the three branches, $\$ 0.9$ billion to the two subsidiaries and $\$ 98$ million to the only true BVI bank, National Bank of the Virgin Islands Limited. Consequently, the FSC is the ultimate supervisor for one bank only, which represents about 4 percent of the banking assets of the jurisdiction. The FSC is the primary supervisor for banks representing 36 percent of the banking assets and has a collaborative role for the supervision of banks representing 60 percent of the banking assets, along with the primary and ultimate supervisors of these branches.

13. The banking system is well capitalized; the aggregate equity to total assets is 16 percent. The system is also highly liquid; of the aggregate balance-sheet size of $\$ 2.5$ billion, $\$ 927$ million (37 percent) takes the form of liquid assets. Almost all of these liquid assets are placed with the head office/parent bank overseas, as there is no interbank bank market in the BVI.

14. The FSC has a detailed knowledge of the banking system. Because of the small size of the banking market in the jurisdiction; the static nature of its activities; and the fact that no new banks have been authorized in recent times, the number of banks is continuously falling and none of the banks has overseas subsidiaries or branches, the system is very simple in supervisory terms.

\section{Preconditions for effective banking supervision}

15. The preconditions for effective banking supervision, including a well-developed public infrastructure, are present in the BVI. A legal and accounting regime heavily influenced by international best practice is in place. (Three of the four main auditing firms have representation in the jurisdiction.) 


\section{Main findings}

Objectives, independence, powers, transparency, and cooperation (CP1)

16. In general, the FSC has sufficient autonomy, powers, and resources with clear responsibilities and objectives. However, the appointment terms for the Managing Director should be re-examined. The Managing Director's term of employment is not fixed nor are there stated reasons for his dismissal. Both the Basel Core Principles and international best practice require that reasons for dismissal be made transparent to the public.

17. The FSC should keep the level and training needs of its staff under constant review. While resources appear adequate at present, the FSC's workload is increasing as a result of the introduction of the Regulatory Code and the increasing complexity of banking supervision.

18. There should be explicit provision for the payment by the FSC of costs incurred by staff in defending their actions and/or omissions in performing their duties in good faith.

\section{Licensing and structure criteria (CP 2 to 5)}

19. These criteria are adequate. This represents an improvement over the previous assessment (2004) when it was noted that there were no legal or regulatory rules dealing with major acquisitions by banks. This deficiency was addressed in the Regulatory Code, 2009.

\section{Prudential Regulation and Requirements (CP 6-18)}

20. Capital adequacy rules meet the $\mathbf{1 9 8 8}$ Basel Accord standards. Current revisions to the $\mathrm{RC}$ will add elements of the 1996 Amendment. The FSC is working with the Caribbean Group of Banking Supervisors (CGBS) to implement Basel II. The region will implement the standardized approach. The region had originally planned to implement by 2011, but that date may be revised at the next meeting of the CGBS in May. The foreignowned branches and subsidiaries that operate with a general license are already implementing Basel II in compliance with home-country requirements.

21. Risk management regulations address BCP criteria; however, loan provisioning rules should address general provisions and provisions for expected losses. The FSC requires banks to follow IAS 39 to recognize impaired debt but has not issued guidelines for prudential reserves. In its 2010 revisions to the RC, the principles on provisioning from the Basel Committee on Banking Supervision (BCBS) 2006 paper "Sound Credit and Risk Assessment and Valuation for Loans" will be incorporated.

22. The FSC does not generally impose specific limits on investments but reviews bank-imposed limits. While lending limits and limits for investment in fixed assets are specified in the $\mathrm{RC}$, for other limits such as open foreign exchange positions or interest rate repricing gaps, the FSC requires banks to establish them and for the Board to approve and 
review annually. During its onsite inspections and offsite reviews, the FSC opines on the adequacy of the limits established and requires changes if determined to be inadequate.

\section{Methods of ongoing banking supervision (CP 19 to 21)}

23. The FSC has a well developed system of on-going supervision in place. There is a full on and offsite inspection program in place and a number of skilled staff to undertake this work. The FSC has displayed a readiness and willingness to enforce against non compliance.

\section{Accounting and disclosure (CP 22)}

24. The FSC should seek to shorten the six-month time frame for both the submission to the FSC and the publication of annual audited accounts to three and, at most, four months. It is understood that the reason for the six-month timeframe relates to the workload of auditors, given that most regulated firms share the same financial year-end: December 31.

\section{Corrective and remedial powers of supervisors (CP 23)}

25. The FSC has broad enforcement powers that facilitate prompt remedial action; however, the RC (effective March 31, 2010) is currently in the transition period for implementation and an end-date to the period has not been specified. The FSC is monitoring banks' compliance with the $\mathrm{RC}$ and could issue directives if a bank is considered to be seriously lagging in implementation. The $\mathrm{RC}$ is being amended this summer and it is recommended that a definite transition period be established with a clear end-date when enforcement becomes mandatory.

\section{Consolidated and cross-border banking supervision (CP 24 and 25)}

26. The FSC has broad powers to conduct consolidated supervision and for exchanging information with foreign supervisors; however, of the four locallyincorporated banks in the BVI, none operates subsidiaries or has cross-border operations. The FSC participates in supervisory colleges hosted by the Canadian supervisors (home to one branch and one subsidiary in BVI) and visits Puerto Rico, which is home to two of the local branches.

27. The BVI has a solid legal basis for an effective banking supervisory regime, particularly after the recent enactment of the Regulatory Code, 2009. The challenges facing the FSC lie in the implementation of the rules and regulations under this legislation. While the FSC appears to have sufficient resources to oversee the current range of banking operations, it should keep resources, both in terms of numbers and expertise, under constant review, given the increased workload on foot of the new legislation and the increasing complexity of banking supervision. 


\section{Table 11. British Virgin Islands: Summary Compliance with the Basel Core Principles-ROSCs}

\begin{tabular}{|c|c|}
\hline Core Principle & Comments \\
\hline \multicolumn{2}{|l|}{$\begin{array}{l}\text { 1. Objectives, independence, powers, transparency, } \\
\text { and cooperation }\end{array}$} \\
\hline 1.1 Responsibilities and objectives & $\begin{array}{l}\text { BVI laws and regulations provide an adequate } \\
\text { framework for effective banking supervision. }\end{array}$ \\
\hline 1.2 Independence, accountability and transparency & $\begin{array}{l}\text { The absence in legislation of stated reasons for } \\
\text { removal of the managing director from office } \\
\text { lacks transparency and could give rise to his } \\
\text { dismissal for reasons that might not be in the } \\
\text { best interests of banking supervision. It is } \\
\text { recommended that the managing director } \\
\text { should be subject to the same terms and } \\
\text { conditions as apply to commissioners as a } \\
\text { whole in this respect. It is further recommended } \\
\text { that a fixed term of office for the managing } \\
\text { director be included in legislation. } \\
\text { The FSC should keep the level and training } \\
\text { needs of staff under constant review, given its } \\
\text { increased workload and the increasing } \\
\text { complexity of banking supervision. }\end{array}$ \\
\hline 1.3 Legal framework & $\begin{array}{l}\text { A suitable framework for effective banking } \\
\text { supervision exists. }\end{array}$ \\
\hline 1.4 Legal powers & $\begin{array}{l}\text { The FSC has sufficient legal powers to carry out } \\
\text { its regulatory functions. }\end{array}$ \\
\hline 1.5 Legal protection & $\begin{array}{l}\text { While the FSC may, in fact, pay the costs of } \\
\text { staff in defending their actions and/or omissions } \\
\text { in performing their duties in good faith, it is } \\
\text { suggested that the payment of such costs be } \\
\text { explicitly provided for. }\end{array}$ \\
\hline 1.6 Cooperation & $\begin{array}{l}\text { The FSC has clear authority to share } \\
\text { information with other supervisors and require } \\
\text { that such information be kept confidential. }\end{array}$ \\
\hline 2. Permissible activities & $\begin{array}{l}\text { The legislation clearly requires that the activity } \\
\text { of deposit-taking be undertaken by banks only } \\
\text { and that the term 'bank' is adequately protected. }\end{array}$ \\
\hline 3. Licensing criteria & $\begin{array}{l}\text { The FSC has adequate licensing powers both in } \\
\text { terms of approving and rejecting applications. }\end{array}$ \\
\hline 4. Transfer of significant ownership & $\begin{array}{l}\text { The FSC has sufficient powers to review } \\
\text { (approve/reject) proposals re the transfer of } \\
\text { significant interests in existing banks. }\end{array}$ \\
\hline
\end{tabular}




\begin{tabular}{|l|l|}
\hline \multicolumn{1}{|c|}{ Core Principle } & \multicolumn{1}{|c|}{ Comments } \\
\hline 5. Major acquisitions & $\begin{array}{l}\text { The FSC has sufficient powers to review } \\
\text { (approve/reject) major acquisitions and } \\
\text { investments by banks. }\end{array}$ \\
\hline 6. Capital adequacy & $\begin{array}{l}\text { Existing laws and regulations require all banks } \\
\text { to consistently maintain a minimum capital ratio. } \\
\text { The RC establishes the requirements for capital } \\
\text { in compliance with Basel requirements (1988). } \\
\text { The regulations grant the FSC broad } \\
\text { enforcement powers to correct noncompliance } \\
\text { with laws and regulations. }\end{array}$ \\
\hline 7. Risk management process & $\begin{array}{l}\text { Amendments to the RC are pending for market } \\
\text { risk derived from trading accounts and to } \\
\text { expand loan-loss provisioning requirements to } \\
\text { include provisions for expected losses and } \\
\text { general reserves. }\end{array}$ \\
\hline 8. Credit risk & $\begin{array}{l}\text { The FSC onsite inspections require the } \\
\text { inspectors to confirm compliance with credit risk } \\
\text { management guidelines established by the } \\
\text { Board of the banks. These include reviews to } \\
\text { determine that a well-documented strategy and } \\
\text { sound policies and processes for assuming } \\
\text { credit risk are in place. }\end{array}$ \\
\hline 9. Problem assets, provisions, and reserves & $\begin{array}{l}\text { The FSC has not implemented a regime of } \\
\text { provisioning to fully cover expected losses or } \\
\text { establish general reserves. Amendments to the } \\
\text { RC will address this deficiency and are } \\
\text { expected to be made in 2010. }\end{array}$ \\
\hline 11. Exposure to related parties & $\begin{array}{l}\text { The RC establishes an aggregate exposure limit } \\
\text { to a counterparty (aggregating related parties) of } \\
\text { 25 percent of capital and an aggregate limit of } \\
800 \text { percent for large credits. The FSC verifies } \\
\text { compliance during onsite inspections and } \\
\text { monitors concentrations through off-site reviews } \\
\text { of bank filings. }\end{array}$ \\
\hline $\begin{array}{l}\text { The RC defines connected parties, including } \\
\text { companies that may be owned by those } \\
\text { connected to the bank. Further, it requires that } \\
\text { connected lending be on an arms-length basis, } \\
\text { approved by senior management or the Board if } \\
\text { exceeding certain levels set by the bank. }\end{array}$ \\
\hline $\begin{array}{l}\text { Banks are required to set country risk limits. The } \\
\text { FSC monitors compliance with Board-set } \\
\text { guidelines during onsite inspections. }\end{array}$ \\
\hline
\end{tabular}




\begin{tabular}{|l|l|}
\hline \multicolumn{1}{|c|}{ Core Principle } & \multicolumn{1}{c|}{ Comments } \\
\hline 13. Market risks & $\begin{array}{l}\text { The FSC in its supervisory process monitors the } \\
\text { market risk prevalent in BVI. The FSC also } \\
\text { closely cooperates with home-country } \\
\text { supervisors to determine support available from } \\
\text { the head office. However, given that the NB may } \\
\text { be expanding its activities and has already } \\
\text { experienced losses from MBS investments, the } \\
\text { FSC should codify market risk guidance related } \\
\text { to trading. }\end{array}$ \\
\hline 14. Liquidity risk & $\begin{array}{l}\text { The RC requires banks to establish liquidity } \\
\text { management strategies and policies, and banks } \\
\text { must file liquidity reports. The onsite inspection } \\
\text { procedures include a review of liquidity } \\
\text { management. }\end{array}$ \\
\hline 15. Operational risk & $\begin{array}{l}\text { Banks are required to establish and maintain } \\
\text { strategies and policies appropriate to its size } \\
\text { and complexity for the monitoring and } \\
\text { controlling of operational risk. The Board must } \\
\text { approve and review such policies on an annual } \\
\text { basis. The FSC reviews business continuity } \\
\text { plans as part of its onsite inspections. }\end{array}$ \\
\hline 20. Supervisory techniques & $\begin{array}{l}\text { The RC requires banks to establish risk } \\
\text { management strategies and policies for interest } \\
\text { rate risk management. During its onsite } \\
\text { inspections the FSC reviews compliance with } \\
\text { existing policies and reviews the banks' interest } \\
\text { rate risk positions.. }\end{array}$ \\
\hline 16. Interest rate risk in the banking book & $\begin{array}{l}\text { Banks are required to have in place adequate } \\
\text { internal controls and these must be subject to } \\
\text { appropriate independent internal and external } \\
\text { audit. }\end{array}$ \\
\hline 18. Abuse of financial services & $\begin{array}{l}\text { The BVI has appropriate AML procedures in } \\
\text { place. }\end{array}$ \\
\hline 17. Internal control and audit & $\begin{array}{l}\text { The FSC approach to banking supervision is in } \\
\text { line with best international practice. }\end{array}$ \\
\hline $\begin{array}{l}\text { The FSC has an appropriate and effective } \\
\text { combination of on-site and off-site supervisory } \\
\text { practices in place. }\end{array}$ \\
\hline $\begin{array}{l}\text { The banks make regular supervisory reports to } \\
\text { the FSC and these are verified by on-site } \\
\text { inspections. }\end{array}$ \\
\hline
\end{tabular}




\begin{tabular}{|l|l|}
\hline \multicolumn{1}{|c|}{ Core Principle } & \multicolumn{1}{c|}{ Comments } \\
\hline 22. Accounting and disclosure & $\begin{array}{l}\text { It is suggested that the six-month deadline for } \\
\text { both the submission to the Commission and for } \\
\text { the publication of financial statements be } \\
\text { reduced to three or at most four months. (It is } \\
\text { understood that the reason for the six-month } \\
\text { time frame relates to the work load of auditors, } \\
\text { given that most firms share the same financial } \\
\text { year end, i.e., December 31.) }\end{array}$ \\
\hline 23. Corrective and remedial powers of supervisors & $\begin{array}{l}\text { Legislation provides the FSC with broad } \\
\text { enforcement authority. The FSC may revoke or } \\
\text { suspend a license, appoint an examiner to } \\
\text { conduct an investigation, require the bank to } \\
\text { appoint an administrator, issue directives } \\
\text { addressing specific areas in need of correction, } \\
\text { and impose penalties. }\end{array}$ \\
\hline 24. Consolidated supervision & $\begin{array}{l}\text { The banks in BVI operate without subsidiaries. } \\
\text { The one locally-incorporated bank for which the } \\
\text { FSC would be home-country supervisor does } \\
\text { not have cross-border operations. }\end{array}$ \\
\hline 25. Home-host relationships & $\begin{array}{l}\text { The FSC has broad powers to exchange } \\
\text { information and collaborate with home-country } \\
\text { supervisors and has demonstrated a willingness } \\
\text { to collaborate with other supervisors. }\end{array}$ \\
\hline
\end{tabular}


Recommended action plan

\section{Table 12. Recommended Action Plan to Improve Compliance with the Basel Core Principles}

\begin{tabular}{|l|l|}
\hline \multicolumn{1}{|c|}{ Reference Principle } & \multicolumn{1}{|c|}{ Recommended Action } \\
\hline $\begin{array}{l}\text { CP 7 - Risk Management Process, CP 9- Problem } \\
\text { Assets, Provisions and Reserves, CP 13- Market }\end{array}$ & $\begin{array}{l}\text { Complete process already initiated to amend the } \\
\text { RC to include provisions on market risk of trading } \\
\text { accounts and provisioning to address possible } \\
\text { losses and general reserves. }\end{array}$ \\
\hline CP1- Resources & $\begin{array}{l}\text { Keep level and training needs of staff under } \\
\text { constant review, given FSC's increasing work load } \\
\text { and increasing complexity of banking supervision. }\end{array}$ \\
\hline CP 1- Appointment of Managing Director & $\begin{array}{l}\text { Fix term of appointment and introduce stated } \\
\text { reasons for his dismissal. }\end{array}$ \\
\hline CP 1- Legal protection for staff & $\begin{array}{l}\text { The FSC should ensure that staff has their costs } \\
\text { paid in the defense of their actions and/or } \\
\text { omissions in carrying out their supervisory } \\
\text { functions in good faith. }\end{array}$ \\
\hline CP 22 - Accounting and disclosure & $\begin{array}{l}\text { The FSC should seek to have shortened the six- } \\
\text { month time frame for both the submission to the } \\
\text { FSC and the publication of annual audited } \\
\text { statements by regulated firms to three or at most } \\
\text { four months. }\end{array}$ \\
\hline
\end{tabular}

\section{Authorities' response to the assessment}

28. The FSC welcomes the IMF's assessment of its compliance against the BCP. The Commission wishes to commend the assessors for their efforts to understand the BVI regulatory framework and thanks them for their skill and diligence in conducting the exercise. The review validates the hard work and progress made by the Commission in strengthening the entire regulatory framework since the last assessment in 2004. The Commission is committed to fully considering the recommendations made and acting accordingly. 


\section{B. FATF Recommendations for Anti-Money Laundering and Combating the Financing of Terrorism}

\section{Introduction}

1. This Report on the Observance of Standards and Codes (ROSC) for the FATF 40 Recommendations for Anti-Money Laundering (AML) and 9 Special Recommendations on Combating the Financing of Terrorism (CFT) was prepared by Mrs. Maxine Hypolite-Bones (financial expert from the Central Bank of Trinidad and Tobago), Ms. Ingrid de Vries (financial expert from the Central Bank of the Netherlands), Mrs. Sandra Edun-Watler (legal expert from the Cayman Islands Monetary Authority), Mr. John Maxwell (law enforcement expert from the Royal Barbados Police Force), and Mr. Roger Hernandez from the Caribbean Financial Action Task Force (CFATF) Secretariat. The report provides a summary of the anti-money laundering/combating the financing of terrorism (AML/CFT) measures in place in the British Virgin Islands and of the level of compliance with the FATF 40+9 Recommendations, and contains recommendations on how the AML/CFT system could be strengthened. The assessment is based on the information available at the time of the mission from February 11-22, 2008, and was conducted using the 2004 Assessment Methodology. The Mutual Evaluation Report on which this document is based was adopted by the CFATF Plenary held during November 17-21, 2008. The views expressed here, as well as in the detailed assessment report, are those of the CFATF and do not necessarily reflect the views of the government of the Virgin Islands or the Executive Board of the International Monetary Fund.

\section{Key findings}

2. The British Virgin Islands' legal framework for combating money laundering (ML) and terrorism financing (FT) is comprehensive. While ML offences are applicable to all indictable offences, insider trading and market manipulation are not specifically criminalized. The low number of ML prosecutions suggests a limited implementation of the legal framework. The criminalization of FT is in accordance with FATF requirements. The confiscation regime meets most standards and is effective.

\section{The Virgin Islands' financial intelligence unit— the Financial Investigation} Agency (FIA) - is effective and is a focal point of the AML/CFT regime. The law enforcement and prosecutorial authorities are adequately empowered and competent to investigate and prosecute ML and FT offences. Requirements for a combined declaratory and disclosure system for the cross-border movement of cash and negotiable monetary instruments are in place. 
4. The preventive system for financial institutions incorporates most of the FATF Recommendations and applies to a range of financial institutions and designated nonfinancial businesses and professions (DNFBPs) as defined by the FATF. While there are measures in place to deal with customer-due-diligence (CDD) requirements, a number have not been enacted legislatively as required by the FATF standards. Record-keeping, monitoring and reporting requirements are extensive. Wire transfer requirements comply with FATF standards except for monetary penalties not being dissuasive.

5. Requirements for internal procedures, policies and controls are comprehensive and include most FATF obligations. The Financial Services Commission (FSC) is the supervisory authority, responsible for monitoring AML/CFT compliance of all financial institutions and DNFBPs as defined by the FATF. Supervision is comprehensive but the low number of on-site inspections demonstrates limited inspection coverage and is probably the result of an inadequate number of staff. All DNFBPs are included in the AML/CFT framework and are subject to the same AML/CFT requirements as financial institutions and deficiencies noted with regard to these requirements are also applicable to DNFBPs.

6. The provision of corporate and trust services are regulated activities subject to the AML/CFT requirements and the supervision of the FSC. Supervisory, law enforcement, and judicial authorities have power to readily access information on beneficial ownership and trusts from financial and trust service providers. The Virgin Islands has a system for registering nonprofit organizations (NPOs). While the FIA is responsible for monitoring and supervising NPOs, no supervisory program was in place at the time of the assessment to identify noncompliance.

7. There is a high degree of cooperation among competent authorities in the Virgin Islands in operational matters related to AML/CFT. A wide range of mutual legal assistance is available in criminal matters. Money laundering, terrorist financing, and terrorism offences are extraditable offences. In general, law enforcement, the FIA, and supervisors can engage in a wide range of international cooperation.

\section{Legal systems and related institutional measures}

8. Money laundering has been criminalized under the Proceeds of Criminal Conduct Act, 1997 (POCCA) and the Drug Trafficking Offences Act, 1992 (DTOA). ML offences include receiving, possessing, concealing, disposing of, importing, or exporting the proceeds of criminal conduct. The physical and material elements of the ML offence include all aspects of the relevant UN Conventions with the exception of certain controlled drugs as required by the Vienna Convention. While the money laundering offences are applicable to all indictable offences, insider trading and market manipulation are not specifically criminalized in the Virgin Islands. 
9. The offence of ML extends to any type of property and applies to persons who commit the predicate offence. Criminal liability extends to legal persons and proof of knowledge can be drawn from objective circumstances. The low number of ML prosecutions suggests a limited implementation of the legal framework.

10. Terrorist financing is criminalized in accordance with the FT Convention in the Terrorism (United Nations Measures) (Overseas Territories) Order 2001(U.K. S.I. 2001 No. 3366) (TUNMOTO), the Anti-Terrorism (Financial and Other Measures) (Overseas Territories) Order 2002, (U.K.S.I No. 2002 No. 1822) (ATFOMOTO) and the Al-Qa'ida and Taliban (United Nations Measures) (Overseas Territories) Order 2002 (ATUNMOTO). These were extended to the Virgin Islands by the United Kingdom government. The components of the FT offence capture funding for individual terrorists or terrorist organizations. Funds are defined in accordance with the FT Convention. A range of secondary offences are covered, terrorist financing offences are predicate offences for ML, and objective factual circumstances may be used to prove intent. Both natural and legal persons are subject to criminal sanctions. There is no evidence of terrorists in the Virgin Islands and there have been no cases of FT in the Virgin Islands.

11. Provision is made for confiscation, freezing, and seizure of the proceeds of crime under the POCCA, the DTOA, the ATFOMOTO, and the TUNMOTO. Confiscation of instrumentalities used in or intended for use in the commission of ML or other predicate offences is allowed. Confiscation is not targeted on specific assets, as it is value-based. Current measures include the freezing and/or seizure of property to prevent any dealing, transfer or disposal of property subject to confiscation. Police have powers to identify and trace property, and the rights of bona fide third parties are protected. At the time of the mutual evaluation visit, over $\$ 45$ million was being held under an interim freeze order (this amount was subsequently confiscated by the High Court to be shared equally with Bermuda).

12. Freezing of funds used for FT, and funds and assets of specific criminal and terrorist organizations, are included within the domestic laws of the Virgin Islands. Laws and procedures are in place to freeze pursuant to S/RES/1267 and S/RES/1373. There is provision to give effect to foreign freezing orders and specific directions to financial institutions are issued with relevant notices and restraint orders. Affected persons can apply for reasonable access to frozen funds or assets and the rights of bona fide third parties are protected. No terrorist funds have been discovered in the Virgin Islands. The various agencies appear to be adequately structured, funded, and resourced to effectively carry out their functions.

13. The FIA was established by the Financial Investigation Agency Act, 2003 (FIAA) with its main function, including receiving, obtaining, investigating, analyzing, and disseminating information which relate to a financial offence or the proceeds of such an offence. The FIA receives SARs from various reporting institutions and has access to a 
number of open source databases. The FIA can request information from reporting financial institutions, government agencies, and statutory bodies. It is an autonomous body and while it is dependent on the government and the FSC for finances, it controls its budget. The staff of the FIA is highly professional and has received training in ML, FT and criminal intelligence analysis. As a member of Egmont, the FIA freely exchanges information with its Egmont partners. Annual reports are legally required to be published, which contain limited details on some ongoing cases. No typologies are included in these annual reports.

14. The position of Director of Public Prosecutions (DPP) was established under section 59 of the Virgin Islands Constitution Order 2007, and has complete independence in the exercise of powers conferred by the Order. The DPP's office is responsible for the prosecution of all offences within the Virgin Islands, which include ML and FT matters. Confiscation, freezing, and forfeiture of criminal proceeds fall within the scope of the office. The DPP's office has a staff complement of 10 persons, including the DPP. Provisions have been made to increase the staff in order to improve efficiency. Staff has been trained in techniques relevant to the prosecution of AML/CFT matters.

15. At present, the Virgin Islands operate a declaration system for incoming crossborder transportation of currency or bearer negotiable instruments and a disclosure system for outgoing transportation of same. Customs officers have the authority to make enquiries of travelers and can confiscate cash suspected of being related to criminal activity. Information obtained from false declarations and disclosures are forwarded to the Joint Intelligence Unit and the FIA. The Customs Department works in close collaboration with the police and immigration officials. Several officers of the Customs Department have been sensitized to AML/CFT matters.

\section{Preventive measures - financial institutions}

16. The POCCA, DTOA, the Anti-money Laundering and Terrorist Financing Code of Practice (AMLTFCOP), and the Anti-money Laundering Regulations, 2008 (AMLR) provide the legal framework for CDD requirements for regulated (natural and legal) persons in the financial sector, although the scope of each of the enactments extends to cover nonregulated entities. The AMLTFCOP and the AMLR were enacted during the mutual evaluation visit and represented revisions of the Anti-money Laundering Guidance Notes, 1999; and the Anti-money Laundering Code of Practice, 1999 respectively. Regulated persons are defined as entities, including DNFBPs, as identified in accordance with the FATF Recommendations, which are regulated by the FSC. The AMLTFCOP consists of sections detailing requirements and attached explanations to provide guidance. Since section 2 (2) of the AMLTFCOP states that the explanations merely provide guidance and clarity to the provisions, the explanations are not considered enforceable by the assessment team.

17. Customer due-diligence measures are generally comprehensive and include customer identification, beneficial ownership requirements, ongoing due diligence, 
measures for politically exposed persons, and correspondent banking. These measures are generally applied by the interviewed financial institutions. The main shortcomings are that some requirements are not set out in law or in other enforceable means as required by the FATF standards and effective implementation of AML/CFT measures cannot be assessed due to recent enactment of the AMLTFCOP. With regard to new technologies, there was no specific requirement for financial institutions to have policies to prevent misuse of technological developments in ML or FT or to address risks associated with nonface-to-face business relationships or transactions.

18. Obligations for introduced business include all FATF measures, except the requirement for financial institutions to immediately obtain from third parties necessary information concerning certain elements of the CDD process in criteria 5.3 to 5.6. There are no financial secrecy laws in the Virgin Islands. Information can be obtained either by production of a court order or by the competent authorities, namely the FSC or the FIA, with appropriate authorization. There is a comprehensive framework of international cooperation legislation and procedures to assist foreign judicial, law enforcement, prosecutorial, tax, and regulatory authorities. There are no restrictions on the sharing of information between financial institutions.

19. Record-keeping requirements are extensive and generally observed. However, record retention of identification data is limited to five years after the last transaction of an account rather than the termination of the account, and there is no requirement for account files and business correspondence to be maintained for at least five years following the termination of an account or business relationship. Wire-transfer requirements comply with FATF standards, except that the monetary penalties in the AMLTFCOP are not dissuasive.

20. Financial institutions are required to maintain records on the activities relating to complex or unusual large or unusual patterns of transactions which do not have any apparent economic or visible lawful purpose. However, there is no requirement to examine these transactions and set forth the findings in writing and keep those findings available for at least five years. Financial institutions are required to carry out enhanced CDD in relation to customers from countries which do not or insufficiently apply the FATF Recommendations. However, there is no requirement for the examination of transactions with no apparent economic or visible lawful purpose from countries that do not, or insufficiently apply, FATF Recommendations and making available the findings to assist competent authorities. The Virgin Islands can, however, apply appropriate counter-measures to countries that do not, or insufficiently apply, the FATF Recommendations.

21. Section 30A of the POCCA makes it an offence for a person not to report to the FIA any knowledge or suspicion of ML acquired in the course of his trade, profession, business, or employment. While ML offences are applicable to all indictable offences, insider trading and market manipulation are not specifically criminalized in the Virgin 
Islands. The current legislation in the Virgin Islands deals with the reporting of suspicious transactions, including attempted transactions. There are no exemptions for the reporting of suspicious transactions. There is a mandatory obligation on all financial institutions in the Virgin Islands to file suspicious transactions reports where the suspicion is in relation to terrorism and FT as stipulated in the provisions of TUNMOTO and ATFOMOTO.

22. Financial institutions and their directors, officers and employees are protected from both criminal and civil liability for reporting SARs in good faith. The safe harbor provision is extended to the FIA, its Director, officers and personnel in discharging their functions. The provision for tipping off is limited to after the submission of a disclosure to the FIA and therefore does not fully comply with FATF obligations. The FIA advised the assessment team that acknowledgement letters are sent upon receipt of any SAR to the reporting entity. The responses from the interviewed entities were split in respect to whether there was an official response from the FIA on the respective SARs. Most, however, reported having a good relationship with the FIA.

23. The requirements for internal procedures, policies, and controls in the AMLTFCOP are comprehensive and include all FATF obligations, except for mandating that financial institutions maintain an adequately resourced and independent audit function. Financial institutions are required to ensure that their foreign branches, subsidiaries, or representative offices observe standards at least equivalent to the AMLR and the AMLTFCOP to the extent permitted by the laws of the foreign jurisdictions. However, there is no requirement for financial institutions to pay particular attention that consistent AML/CFT measures are observed with respect to their branches and subsidiaries in countries which do not or insufficiently apply the FATF Recommendations. Additionally, financial institutions are not required to inform their home-country supervisor when a foreign branch or subsidiary is unable to observe appropriate AML/CFT measures because this is prohibited by local laws, regulations or other measures. However, at the time of the on-site inspection, no local entity had foreign branches, subsidiaries or representative offices. Most entities were branches, subsidiaries or representative offices of multinational institutions. 
24. While shell banks are not directly prohibited in law in the Virgin Islands, the requirements for the establishment and licensing of a bank effectively prevents the operation of shell banks in the jurisdiction. The AMLTFCOP prohibits entities from entering into, or maintaining a correspondent relationship with a shell bank and prohibits banks from entering into or maintaining a relationship with a respondent bank that provides correspondent banking services to a shell bank.

25. The FSC is the competent authority that monitors AML/CFT compliance by financial institutions and DNFBPs who provide financial services. The FSC's supervisory function relates to the financial institutions that are subject to financial services legislation including the Banks and Trust Companies Act, 1990 (BTCA), the Company Management Act, 1990(CMA), the Insurance Act, 1994 (IA), the Mutual Funds Act, 1996 (MFA), POCCA and the Insolvency Act, 2003. The FSC also incorporates the Registry of Corporate Affairs, which deals with the incorporation and registration of legal persons.

26. The FSC is responsible under the regulatory laws for all licensing, enforcement, and administrative decisions with respect to all relevant financial services businesses. The FSC's regulatory functions are carried out by professional staff in four regulatory and supervisory divisions, three nonsupervisory divisions, and four support units. Staff is duly qualified and must be fit and proper to hold their posts. In addition to in-house training sessions organized throughout the year, staff has been exposed to AML/CFT training workshops and seminars held regionally and internationally.

27. The FSC has a broad range of powers to monitor and ensure financial institutions' compliance with AML/CFT measures, which include off-site surveillance and on-site prudential visits and inspections. The FSC utilizes a risk-based approach in developing its on-site inspection program. On-site inspections have increased from 2004 to 2007, especially in the fiduciary services and insurance divisions. However, only two out of a total of nine banks were examined during the period. There were no on-site visits on mutual fund managers or administrators. With regard to registered agents, the FSC completed a total of 41 inspections during the years 2004-2007, representing 37 percent of registered agents accounting for only 25 percent of the total number of registered companies. The low number of on-site examinations in relation to the total number of financial institutions demonstrates limited inspection coverage by the FSC and is probably the result of an inadequate number of staff.

28. Under various provisions of the Financial Services Commission Act (FSCA), the FSC may require the provision of any information or the production of any documents that may be reasonably required in connection with the FSC's regulatory functions, including internal audit reports. The record-keeping requirements, together with various access provisions for the benefit of both law enforcement and regulatory authorities, ensure 
that both customer and transaction records are accessible and available to the FSC as required.

29. In general, criminal sanctions are available for offences under the POCCA and DTOA and their respective amendments, TUNMOTO, ATFOMOTO, and ATUNMOTO, and are applicable to all natural and legal persons. The FSCA authorizes the FSC to apply relevant sanctions through enforcement actions, which include revocation or suspension of licenses and the imposition of prohibitions, limitations, or restrictions. Sanctions for noncompliance with AML/CFT obligations in the AMLTFCOP are specified in section 27 of the POCCA. These sanctions can only be imposed by the court through proceedings brought by the DPP. Additionally, the AMLTFCOP allows for the FSC to impose administrative penalties, which do not exceed $\$ 4,000$. Sanctions for noncompliance with the requirements of the AMLR range from $\$ 5,000$ to $\$ 15,000$. Monetary penalties applicable for offences under the AMLTFCOP and the AMLR, ranging from $\$ 4,000$ to $\$ 15,000$, are considered too low to be dissuasive to financial institutions operating in the Virgin Islands.

30. The Financing and Money Services Act, 2007 (FMSA) is due to come into effect in 2008. It outlines the licensing requirements for money service businesses (MSBs) in the Virgin Islands. At the time of the assessment, money remitters in the Virgin Islands were not subject to licensing or registration requirements or supervision. The AMLFTCOP was drafted and issued by the FSC in collaboration with the Joint Anti-money Laundering and Terrorist Financing Advisory Committee (JALTFAC). It was enacted in February 2008 and stipulates preventive AML/CFT measures for financial institutions and DNFBPs. Due to the recent enactment of the AMLTFCOP, the examiners were not able to assess its effective implementation.

\section{Preventive measures - designated nonfinancial businesses and professions}

31. Section 27 of the POCCA, 2008 extends the coverage of the AML/CFT regime to include DNFBPs. The definition of "regulated person" in the AMLTFCOP includes provisions for DNFBPs. The AML/CFT requirements applicable to financial institutions in the AMLR and the AMLTFCOP are also applicable to the DNFBPs. It should be noted that of the DNFBPs, only company managers and trust and company service providers as licensees of the FSC are actively monitored and supervised for compliance with AML/CFT requirements. Deficiencies noted with regard to the AML/CFT regime for financial institutions in relation to specific Recommendations are also applicable to DNFBPs. 


\section{Legal persons and arrangements and nonprofit organizations}

32. The Registry of Corporate Affairs maintains individual registers for companies, foreign companies and charges. Registration of companies is governed by the BVI Business Companies Act, 2004 (BVIBCA) (and amendments). Section 6 of the BVIBCA requires that applications to incorporate a company be made to the Registrar. An application for incorporation of a company may be filed only by the proposed registered agent. Customer due diligence, identity verification or background checks regarding organizers or beneficial owners of registered entities are required to be performed by registered agents. Registered agents are under the supervision of the FSC and are also subject to the AML/CFT requirements of the AMLTFCOP, which mandate the identification of beneficial owners with regard to corporate clients, trusts, and fiduciary clients.

33. According to section 9 of the BVIBCA, a company limited by shares can issue bearer shares. Under the BVIBCA, international business companies that were incorporated before January 1, 2005, and issued bearer shares had until December 31, 2009 to place their bearer shares with an authorized or recognized custodian or to immobilize them. IBCs formed after January 1, 2005 are required to immobilize all bearer shares from their date of formation.

34. Information on beneficial ownership of registered companies maintained by registered agents is accessible by all competent authorities. The relatively low number of FSC inspections makes it difficult to assess whether the information on beneficial ownership is being adequately and accurately maintained.

35. There is no central filing requirement for trusts and no register of all trusts in the Virgin Islands. Information on trusts is maintained by licensed trust-service providers and can be readily accessed through the investigative and examination powers of the regulatory and law enforcement authorities under the relevant statutes. Trust-service business is a regulated activity under the BTCA and is governed by the AMLTFCOP and the AMLR. The record-keeping provisions of the AMLTFCOP require licensed trust service providers to ensure that records are readily available for timely access by the competent authorities. The concern regarding information on beneficial ownership of companies is also applicable to the information on trusts, although the trust and company service providers have indicated their awareness and compliance with AML/CFT laws.

36. The regime for NPOs is governed by the BVIBCA. The assessment team was advised by the FSC that the NPO population is considered "low risk" for potential ML and FT activities. Every NPO is required to have a registered agent in the Virgin Islands. No evidence was presented to the assessors that the authorities had reviewed these laws with regard to protecting NPOs from being used to finance terrorism. No competent authority has undertaken any formal outreach efforts to the NPO sector regarding AML/CFT requirements 
or best practices. The assessment team was advised that the vast majority of NPOs operate exclusively in the Virgin Islands, serving the needs of the domestic community. Moreover, no NPO is viewed by the government as controlling a portion of the sector's financial resources.

37. The Registrar of Corporate Affairs is able to identify, with the introduction of the new registration system "VIRRGIN", companies that are registered as NPOs. Information on an NPO, which has the legal form of a company and is registered as such, is publicly available. There are no competent authorities engaged in any formal monitoring of NPOs that do have the legal form of a company, after their registration. The FIA is the competent authority, according to section 9 (2) of the AMLTFCOP, to monitor and supervise NPOs. At the time of the assessment, the FIA had no supervisory program in place to identify noncompliance and violations by NPOs.

\section{National and international cooperation}

38. Relevant and competent authorities in the Virgin Islands maintain close working relationships. These include the FIA, the FSC, the RVIPF, the Immigration Department, the Customs Department, the Attorney General's Chambers, and the Office of the Director of Public Prosecutions. The main national coordination body overseeing the AML/CFT regime in the Virgin Islands is the Joint Anti-money Laundering and Terrorist Financing Advisory Committee (JALTFAC), which consists of members drawn from the public and private sectors. The Virgin Islands is constantly reviewing and amending laws to take into account all relevant developments, and the principal legislation governing AML/CFT matters have been reviewed on an ongoing basis.

39. The Virgin Islands, as an Overseas Territory, has no legal power to ratify or accede to any international treaty and such ratification or accession is carried out on its behalf by the government of the United Kingdom. However, the Virgin Islands can enact legislation domestically to implement the provisions of relevant international treaties and Conventions. The Vienna Convention was ratified by the U.K. government and extended to the Territory on February 8, 1995. The Palermo Convention and the Terrorist Financing Convention were not extended to the Virgin Islands. Although the Palermo Convention and the Terrorist Financing Convention have not been extended to the Virgin Islands, they have been given effect under its laws. The provisions of the UN Security Council Resolutions, S/RES/1267(1999) and S/RES/1373(2001) have been implemented by relevant legislation in the Virgin Islands.

40. Assistance can be provided for the full range of mutual legal assistance requests envisaged by the FATF Recommendations. Generally, mutual legal assistance requests are of three types: law enforcement, regulatory breaches/offences, and tax offences. The governor and the attorney general are the central authorities for law enforcement requests, the 
managing director/chief executive officer of the FSC for regulatory breaches and offences, and the Financial Secretary for tax offences. Mutual legal assistance under the CJICA is granted if an offence has been committed under the laws of the requesting country or territory, or there are reasonable grounds to suspect that an offence has been committed and that criminal proceedings or criminal investigations have commenced in the requesting country. Generally, all requests for legal assistance are processed within a period of 30 days from the date of the receipt. Very urgent requests, such as those with close return court dates would be processed in a quicker time period. Generally, all mutual legal assistance provisions apply also to terrorism and terrorism-financing offences.

\section{Money laundering is an extraditable offence in the Virgin Islands. The Virgin} Islands extradites its own nationals pursuant to Part 1 of the Extradition (Overseas Territories) Order 2002. Extradition is available for any conduct that would be an offence if committed within the Virgin Islands. The Virgin Islands can provide assistance in extradition relating to insider trading and market manipulation since the underlying conduct is regarded as equivalent to conspiracy to defraud in the Virgin Islands. This relates, in essence, to all offences wherein the underlying conduct is considered equivalent to an offence in the Virgin Islands even though the offence does not carry the same name.

\section{The Virgin Islands has a comprehensive framework of international cooperation} legislation and procedures to assist foreign judicial, law enforcement, prosecutorial, tax, and regulatory authorities. The framework provides an efficient and effective mechanism for cross-border cooperation and exchange of information. Law enforcement agencies, the FIA, and the FSC can engage in a wide range of international cooperation and they render assistance in a timely fashion. There is no legal hindrance to the constructive and effective provision of such assistance.

\section{Other issues}

43. Most of the competent authorities have adequate resources to carry out their functions. However, the FSC and the ADVCTF have quantitatively inadequate human resources.

44. Comprehensive statistics are generally maintained. However, the RVIPF does not have records on ML investigations that have been carried out or the number of production orders or search warrants that have been executed. 


\section{Table 13. Summary Table of Observance and Key Recommendations}

\begin{tabular}{|c|c|}
\hline $\begin{array}{c}\text { FATF } 40+9 \\
\text { Recommendations }^{15}\end{array}$ & Key Assessor Recommendations \\
\hline \multicolumn{2}{|c|}{ 1. Legal System and Related Institutional Measures } \\
\hline $\begin{array}{l}\text { Criminalization of Money } \\
\text { Laundering } \\
\text { R. } 1-\text { LC } \\
\text { R. } 2-\text { LC } \\
\text { R. } 32-\text { LC }\end{array}$ & $\begin{array}{l}\text { Enact legislation criminalizing market manipulation and insider } \\
\text { trading and banning Vienna Convention scheduled chemicals not } \\
\text { already prohibited. }\end{array}$ \\
\hline $\begin{array}{l}\text { Criminalization of Terrorist } \\
\text { Financing } \\
\text { SR. II - LC } \\
\text { R. } 32-\text { LC }\end{array}$ & \\
\hline $\begin{array}{l}\text { Confiscation, freezing, and } \\
\text { seizing of proceeds of crime } \\
\text { R. } 3-\text { C } \\
\text { R. } 32 \text { - LC }\end{array}$ & \\
\hline $\begin{array}{l}\text { Freezing of funds used for } \\
\text { terrorist financing } \\
\text { SR. III - C } \\
\text { R. } 32-\text { LC }\end{array}$ & \\
\hline $\begin{array}{l}\text { The Financial Intelligence Unit } \\
\text { and its functions } \\
\text { R. } 26-\text { LC } \\
\text { R. } 30-\text { PC } \\
\text { R. } 32 \text { - LC }\end{array}$ & $\begin{array}{l}\text { - The personnel should continue to be exposed to training in the area } \\
\text { of AML/CFT to ensure that they remain on the cutting edge. } \\
\text { Consideration should be given to exposing staff to attachments to } \\
\text { other FIUs to allow them to develop all aspects of their job. } \\
\text { - FIA annual reports should include typologies. } \\
\text { - Efforts should be made to implement electronic delivery of SARs to } \\
\text { the FIA. } \\
\text { - The relevant authorities should consider intensifying their } \\
\text { education/training program with the various entities with respect to } \\
\text { the preparation and filing of SARs. }\end{array}$ \\
\hline $\begin{array}{l}\text { Law enforcement, prosecution } \\
\text { and other competent authorities } \\
\text { R. } 27-\text { C } \\
\text { R. } 28-\text { C } \\
\text { R. } 30-\text { PC } \\
\text { R. } 32-\text { LC }\end{array}$ & $\begin{array}{l}\text { - The ADVCTF should be adequately staffed and trained in the } \\
\text { techniques of ML and FT investigations. } \\
\text { - The RVIPF should maintain adequate statistics on ML investigations, } \\
\text { productions orders and search warrants. }\end{array}$ \\
\hline
\end{tabular}

${ }^{15}$ Compliant (C): the Recommendation is fully observed with respect to all essential criteria. Largely compliant (LC): there are only minor shortcomings, with a large majority of the essential criteria being fully met. Partially compliant (PC): the country has taken some substantive action and complies with some of the essential criteria. Noncompliant (NC): there are major shortcomings, with a large majority of the essential criteria not being met. Not applicable (NA): a requirement or part of a requirement does not apply, due to the structural, legal or institutional features of a country. 


\begin{tabular}{|c|c|}
\hline \multicolumn{2}{|l|}{$\begin{array}{l}\text { Cross-border Declaration or } \\
\text { disclosure SR. IX-C }\end{array}$} \\
\hline \multicolumn{2}{|r|}{ 2. Preventive Measures: Financial Institutions } \\
\hline $\begin{array}{l}\text { Risk of money laundering or } \\
\text { terrorist financing }\end{array}$ & \\
\hline $\begin{array}{l}\text { Customer due diligence, including } \\
\text { enhanced or reduced measures } \\
\text { R. } 5 \text { - PC } \\
\text { R. } 6 \text { - LC } \\
\text { R. } 7 \text { - LC } \\
\text { R. } 8 \text { - PC }\end{array}$ & $\begin{array}{l}\text { The requirement for financial institutions to verify that any person } \\
\text { purporting to act on behalf of customers that are legal persons or } \\
\text { legal arrangements is so authorized, and the identification and } \\
\text { verification of that person should be legislated. } \\
\text { The authorities should issue a list of jurisdictions that they recognize } \\
\text { as having in place measures implementing FATF Recommendations } \\
\text { to allow financial institutions to apply simplified or reduced CDD } \\
\text { measures to customers resident in those countries. } \\
\text { The requirement for entities and professionals to adopt relevant risk } \\
\text { management processes and procedures for permitting a business } \\
\text { relationship before effecting the necessary verification should be } \\
\text { enforceable. } \\
\text { Financial institutions should be required to have policies in place or } \\
\text { take such measures as may be needed to prevent the misuse of } \\
\text { technological developments in money laundering or terrorist } \\
\text { financing. } \\
\text { Financial institutions should be required to have policies and } \\
\text { procedures to address specific risks associated with nonface to face } \\
\text { business relationships or transactions. }\end{array}$ \\
\hline $\begin{array}{l}\text { Third parties and introduced } \\
\text { business } \\
\text { R. } 9-\text { PC }\end{array}$ & $\begin{array}{l}\text { - Financial institutions relying upon a third party should be required to } \\
\text { immediately obtain from the third party the necessary information } \\
\text { concerning certain elements of the CDD process itemized in criteria } \\
5.3 \text { to } 5.6 \text {. }\end{array}$ \\
\hline $\begin{array}{l}\text { Financial institution secrecy or } \\
\text { confidentiality } \\
\text { R. } 4-\text { C }\end{array}$ & \\
\hline $\begin{array}{l}\text { Record keeping and wire transfer } \\
\text { rules } \\
\text { R. } 10-\text { LC } \\
\text { SR. VII -LC }\end{array}$ & $\begin{array}{l}\text { - The AMLTFCOP should be amended to remove the possibility of } \\
\text { identification data being destroyed five years after the last transaction } \\
\text { of an account that has not been formally terminated. } \\
\text { - Account files and business correspondence should be maintained for } \\
\text { at least five years following the termination of an account or business } \\
\text { relationship. } \\
\text { - Penalties and sanctions applicable for obligations of SR. VII in } \\
\text { sections } 37 \text { to } 47 \text { of the AMLTFCOP should be dissuasive. }\end{array}$ \\
\hline $\begin{array}{l}\text { Monitoring of transactions and } \\
\text { relationships } \\
\text { R. } 11-\text { PC } \\
\text { R. } 21-\text { PC }\end{array}$ & $\begin{array}{l}\text { Financial institutions should be required to examine as far as possible } \\
\text { the background and purpose of complex, unusual large transactions } \\
\text { or unusual patterns of transactions that have no apparent or visible } \\
\text { economic or lawful purpose and to set forth their findings in writing. }\end{array}$ \\
\hline
\end{tabular}




\begin{tabular}{|c|c|}
\hline & $\begin{array}{l}\text { - Financial institutions should be required to keep such findings } \\
\text { available for competent authorities and auditors for at least five years. } \\
\text { - Effective measures should be put in place to ensure that financial } \\
\text { institutions are advised of concerns about the weaknesses in the } \\
\text { AML/CFT systems of other countries. } \\
\text { - The background and purpose of transactions with no apparent } \\
\text { economic or visible lawful purpose from countries which do not apply, } \\
\text { or insufficiently apply, the FATF Recommendations, should be } \\
\text { examined and the written findings made available to assist competent } \\
\text { authorities and auditors. }\end{array}$ \\
\hline $\begin{array}{l}\text { Suspicious transaction reports and } \\
\text { other reporting } \\
\text { R. } 13-\text { LC } \\
\text { R. } 14-\text { LC } \\
\text { R. } 19-\text { C } \\
\text { R. } 25-\text { LC } \\
\text { SR. IV - C }\end{array}$ & $\begin{array}{l}\text { - The FIA annual reports should include the results of disclosure and } \\
\text { information on typologies. } \\
\text { - Enact legislation criminalizing insider trading and market } \\
\text { manipulation as predicate offences for money laundering. } \\
\text { - The tipping-off offence should be extended to include disclosure of } \\
\text { the fact that a STR or related information is being reported or } \\
\text { provided to the FIA. }\end{array}$ \\
\hline $\begin{array}{l}\text { Internal controls, compliance, audit } \\
\text { and foreign branches } \\
\text { R. } 15-\text { PC } \\
\text { R. } 22-\text { PC }\end{array}$ & $\begin{array}{l}\text { - Financial institutions should be required to maintain an adequately } \\
\text { resourced and independent audit function to test compliance with } \\
\text { AML/CFT procedures, policies, and controls. } \\
\text { - Financial institutions should be required to pay particular attention } \\
\text { that consistent AML/CFT measures are observed with respect to } \\
\text { their branches and subsidiaries in countries which do not or } \\
\text { insufficiently apply the FATF Recommendations. } \\
\text { - Financial institutions should be required to inform their home country } \\
\text { supervisor when a foreign branch or subsidiary is unable to observe } \\
\text { appropriate AML/CFT measures because this is prohibited by local } \\
\text { laws, regulations or other measures. }\end{array}$ \\
\hline \multicolumn{2}{|l|}{$\begin{array}{l}\text { Shell banks } \\
\text { R. } 18-C\end{array}$} \\
\hline $\begin{array}{l}\text { Supervisory and oversight system- } \\
\text { competent authorities and SROs } \\
\text { Role, functions, duties and powers } \\
\text { (including sanctions) } \\
\text { R. } 17 \text { - PC } \\
\text { R. } 23 \text { - PC } \\
\text { R. } 25 \text { - LC } \\
\text { R. } 29-\text { C } \\
\text { R. } 30 \text { - PC } \\
\text { R. } 32 \text { - LC }\end{array}$ & $\begin{array}{l}\text { - Review sanctions imposed in the AMLR and the AMLFTCOP with a } \\
\text { view to making them dissuasive. } \\
\text { - FSC should review present staff complement with a view to } \\
\text { improving supervisory coverage. } \\
\text { - The FMSA should be enacted as soon as possible. }\end{array}$ \\
\hline $\begin{array}{l}\text { Money value transfer services } \\
\text { SR. VI - NC }\end{array}$ & - The FMSA should be enacted as soon as possible. \\
\hline
\end{tabular}


3. Preventive Measures: Nonfinancial Businesses and Professions

\begin{tabular}{|c|c|}
\hline $\begin{array}{l}\text { Customer due diligence and record- } \\
\text { keeping } \\
\text { R. } 12-\text { PC }\end{array}$ & $\begin{array}{l}\text { Deficiencies identified for all entities and professionals as noted for } \\
\text { Recs. 5, 6, 8-11, in the relevant sections of this report are also } \\
\text { applicable to DNFBPs. Implementation of the specific } \\
\text { recommendations in the relevant sections of this report will also apply } \\
\text { to DNFBPs. }\end{array}$ \\
\hline $\begin{array}{l}\text { Suspicious transaction reporting } \\
\text { R. } 16-P C\end{array}$ & $\begin{array}{l}\text { Deficiencies identified with regard to Recs. } 13 \text { to } 15 \text {, and } 21 \text { are also } \\
\text { applicable to DNFBPs. Implementation of the specific } \\
\text { recommendations in the relevant sections of this report will also apply } \\
\text { to DNFBPs. }\end{array}$ \\
\hline $\begin{array}{l}\text { Regulation, supervision, monitoring, } \\
\text { and sanctions } \\
\text { R. } 24-\text { PC } \\
\text { R. } 25-\text { LC }\end{array}$ & $\begin{array}{l}\text { - Effective systems for monitoring and ensuring compliance with } \\
\text { AML/CFT requirements by real estate agents, lawyers, other } \\
\text { independent legal advisers, accountants, and dealers in precious } \\
\text { metals and stones should be implemented. } \\
\text { - Deficiencies identified regarding sanctions and sufficient resources for } \\
\text { the FSC should be remedied. }\end{array}$ \\
\hline $\begin{array}{l}\text { Other designated nonfinancial } \\
\text { businesses and professions } \\
\text { R. } 20-C\end{array}$ & \\
\hline
\end{tabular}

\section{Legal Persons and Arrangements and Nonprofit Organizations}

Legal Persons-Access to beneficial ownership and control information

- The FSC should implement an effective monitoring system to ensure R. 33 -PC that registered agents are maintaining adequate accurate and current beneficial ownership information.

Legal Arrangements-Access to beneficial ownership and control information

R. 34 - LC

Nonprofit organizations

SR. VIII - PC

- The authorities should review the adequacy of the laws that relate to NPOs and conduct periodic reassessment of the sector's potential vulnerabilities to terrorist activities.

- The authorities should undertake an outreach program to the NPO sector with a view to protecting the sector from terrorist financing abuse.

- A supervisory program for NPOs should be developed to identify noncompliance and violations.

\section{National and International Cooperation}

National cooperation and

coordination

R. $31-\mathrm{C}$

R. $32-$ LC

The Conventions and UN Special

Resolutions

R. 35 - LC

SR. I - LC

- Since these laws have now been implemented locally, active efforts should be made to the United Kingdom to have the Conventions extended to the Territory and provisions put in place for the denial of landing of any aircraft used on behalf of the Taliban and denial of safe haven in accordance with United Nations Security Council Resolution 1373. 


\begin{tabular}{|l|l|}
\hline Mutual Legal Assistance & \\
\hline R. $36-$ C & \\
R. $37-$ C & \\
R. $38-$ C & \\
SR. V - C & \\
R. $32-$ LC & \\
\hline Extradition & \\
R.39-C & \\
R.37 - C & \\
SR.V - C & \\
R. 32 - LC & \\
\hline Other Forms of Cooperation & \\
R. $40-$ C & \\
SR. V - C & \\
R. 32 - LC & \\
\hline \multicolumn{2}{|c|}{ 6. Other Issues } \\
\hline Other relevant AML/CFT measures & \\
or issues & \\
\hline General framework - structural & \\
issues & \\
\hline
\end{tabular}

\section{Authorities' Response}

\section{Table 14. Authorities' Response}

\begin{tabular}{|c|c|}
\hline FATF 40+9 Recommendations & Key Assessor Recommendations \\
\hline \multicolumn{2}{|c|}{ 1. Legal System and Related Institutional Measures } \\
\hline $\begin{array}{l}\text { Criminalization of Money Laundering } \\
\text { R. } 1 \text { - LC } \\
\text { R. } 2 \text { - LC } \\
\text { R. } 32 \text { - LC }\end{array}$ & $\begin{array}{l}\text { - Enact legislation criminalizing market manipulation and insider } \\
\text { trading and banning Vienna Convention scheduled chemicals } \\
\text { not already prohibited. } \\
\text { Part V of the Securities and Investment Business Act (SIBA) } \\
\text { addresses market abuse and makes insider trading and market } \\
\text { manipulation criminal offenses as outlined in Sections } 88 \text { and } 91 \text {, } \\
\text { respectively. The penalties for such acts are also outlined in these } \\
\text { sections of the Act, and the criminalization of such makes them } \\
\text { predicate offenses for money laundering. SIBA had its first reading on } \\
18^{\text {th }} \text { March } 2010 \text { and is awaiting final legislative approval (set for } 12^{\text {th }} \\
\text { March, 2010). } \\
\text { The Criminal Justice (International Cooperation) (Amendment of } \\
\text { Schedule 2) Order, } 2009 \text { which amends Schedule } 2 \text { of the Criminal } \\
\text { Justice (International Cooperation) Act, } 1993 \text { had been drafted and } \\
\text { laid on the Table of the House of Assembly in accordance with the } \\
\text { Act on } 29^{\text {th }} \text { December, } 2009 \text {. It is now awaiting Cabinet approval. The } \\
\text { Order amends Tables I and II of the Act by including the following } \\
\text { substances in its list of banned substances: }\end{array}$ \\
\hline
\end{tabular}




\begin{tabular}{|c|c|}
\hline & $\begin{array}{l}\text { Isosafrole } \\
\text { 3,4-Methylenedioxythenyl-2-Proranone } \\
\text { N-Acetylanthranilic Acid } \\
\text { Norephedrine } \\
\text { Piperonal } \\
\text { Safrole } \\
\text { Hydrochloric Acid } \\
\text { Methyl Ethyl Ketone } \\
\text { Potassium Permanganate } \\
\text { Sulphuric Acid } \\
\text { Toluene }\end{array}$ \\
\hline $\begin{array}{l}\text { Criminalization of Terrorist } \\
\text { Financing } \\
\text { SR. II - LC } \\
\text { R. } 32 \text { - LC }\end{array}$ & \\
\hline $\begin{array}{l}\text { Confiscation, freezing, and } \\
\text { seizing of proceeds of crime } \\
\text { R. } 3-\text { C } \\
\text { R. } 32-\text { LC }\end{array}$ & \\
\hline $\begin{array}{l}\text { Freezing of funds used for } \\
\text { terrorist financing } \\
\text { SR. III - C } \\
\text { R. } 32-\text { LC }\end{array}$ & \\
\hline $\begin{array}{l}\text { The Financial Intelligence Unit } \\
\text { and its functions } \\
\text { R. } 26-\text { LC } \\
\text { R. } 30-\text { PC } \\
\text { R. } 32-\text { LC }\end{array}$ & $\begin{array}{l}\text { The personnel should continue to be exposed to training in the } \\
\text { area of AML/CFT to ensure that they remain on the cutting edge. } \\
\text { Consideration should be given to exposing staff to attachments } \\
\text { to other FIUs to allow them to develop all aspects of their job. } \\
\text { The training needs of members of staff of the FIA are constantly } \\
\text { reviewed. Training in the areas of AML/CFT including analysis and } \\
\text { investigations has been identified and provided. As a member of the } \\
\text { Egmont Group, the FIA is willing to provide training for its staff } \\
\text { through attachments with other FIUs within the Egmont Group. The } \\
\text { Egmont Group is due to develop a plan to facilitate such } \\
\text { attachments. In the meantime, the FIA staff continues to participate } \\
\text { in regional and international training programs geared towards } \\
\text { enhancing skills in the preparation of typologies and the AML/CFT } \\
\text { investigation techniques. } \\
\text { Since the Territory's evaluation in } 2008, \text { a total of eight members of } \\
\text { the FIA's staff have been trained in AML/CFT, all eight in AML/CFT } \\
\text { compliance, one in Financial Analysis, one in Intelligence Analysis, } \\
\text { one in Financial Crimes Analysis and one in Strategic Analysis. } \\
\text { Future training plans include the full certification of the FIA's } \\
\text { analysts and investigators as Anti-money Laundering specialists in } \\
2010 \text {. The Agency is fully committed to identifying and providing the } \\
\text { best available training for its staff and will continue its efforts to keep } \\
\text { its staff fully updated on all aspects of AML/CFT issues. }\end{array}$ \\
\hline
\end{tabular}


- FIA annual reports should include typologies.

> FIA Annual Report now contains details on results of disclosures and information on typologies.

- Efforts should be made to implement electronic delivery of SARs to the FIA.

D The number of SARs filed by reporting entities is relatively small in comparison to other larger jurisdictions and the FIA currently receives, on average, one hundred and fifty SARs per year. While all SARs filed are currently hand delivered, the FIA intends as part of its current plan to encourage regulated institutions to file reports electronically and it is anticipated that provision will be made for the electronic delivery of these reports in the near future. The FIA does, however, feel that the option to hand deliver reports should be maintained as a backup mechanism to the electronic delivery of these reports. Furthermore, because of the size of the jurisdiction and considering the centers of activity, the BVI does not consider the filing of SARs by means other than electronic filing to be ineffective or to cause any delay.

- The relevant authorities should consider intensifying their education/training program with the various entities with respect to the preparation and filing of SARs.

$>$ The FIA provides training on AML/CFT, the reporting of SARs, and the role of the FIA to reporting entities on an ongoing basis. Since 2008 the FIA has provided AML/CFT and SAR reporting training to eleven reporting entities including two of the Territory's banks. The FIA is dedicated to the continued enhancement of its outreach program, which aims to raise awareness of AML/CFT matters within the financial services sector including targeting NPOs and DNFBPs.

$>$ The FSC conducts bi-annual Meet the Regulator Forum which affords it the opportunity to educate the industry on current and emerging AML/CFT trends. Regulated entities are, however, required, under the AMLR and AMLTFCOP, to conduct their own training of staff to ensure that they remain fully aware of their AML/CFT obligations at all times and are fully capable of fulfilling those obligations. Section 47 of the AMLTFCOP states that:

"47.(1) Consistent with the training obligations outlined in the Anti-money Laundering Regulations, 2008, every entity and professional shall, having regard to its commercial or professional disposition and the requirements of this Code, engage in the training of its employees by:

(a) ensuring that they receive appropriate and proportionate training to the standard and level required by the Anti-money 


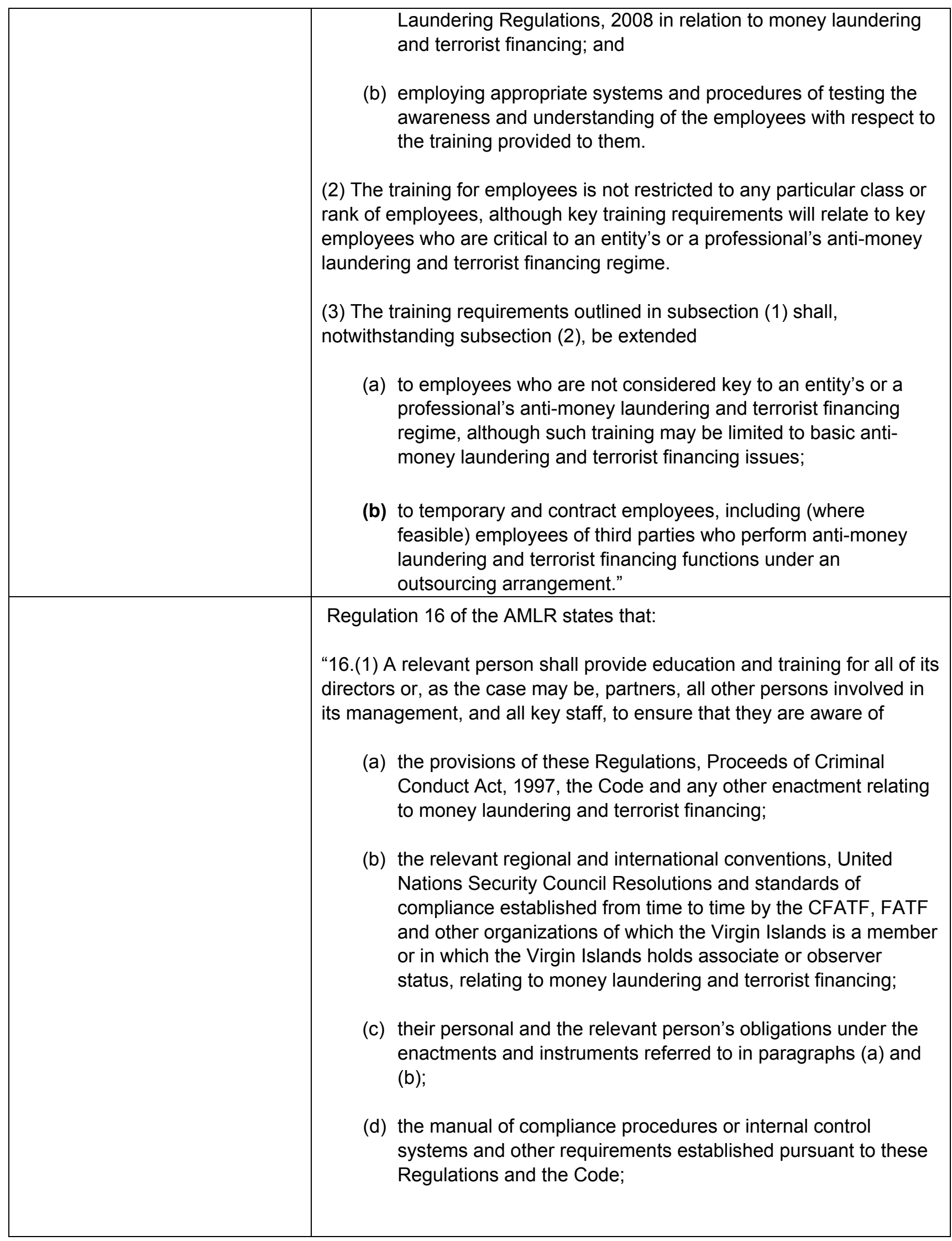




\begin{tabular}{|c|c|}
\hline & $\begin{array}{l}\text { their personal liability for failure to report information or suspicions in } \\
\text { accordance with the requirements of these Regulations, the Code and } \\
\text { any other enactment, including any established internal procedures." }\end{array}$ \\
\hline $\begin{array}{l}\text { Law enforcement, prosecution } \\
\text { and other competent authorities } \\
\text { R. } 27-\text { C } \\
\text { R. } 28-\text { C } \\
\text { R. } 30-\text { PC } \\
\text { R. } 32-\text { LC }\end{array}$ & $\begin{array}{l}\text { - The ADVCTF should be adequately staffed and trained in the } \\
\text { techniques of ML and FT investigations. } \\
\text { It is part of the government's current plan to ensure that officers of } \\
\text { the ADVCTF are sensitized to AML/CFT investigative techniques. Of } \\
\text { the eighteen officers currently assigned to the Task Force, seven } \\
\text { have been trained in AML/CFT. Additional training has been identified } \\
\text { which members of staff are scheduled to participate in within the next } \\
\text { six months. There is also some in-house training slated to take place } \\
\text { shortly. Indeed, it is part of the plan to provide training to members of } \\
\text { the Inter-governmental Committee on AML/CFT and their staff } \\
\text { regarding AML/CFT obligations and investigative techniques } \\
\text { - The RVIPF should maintain adequate statistics on ML } \\
\text { investigations, productions orders and search warrants. } \\
\text { Templates covering the types of statistics that should be collected by } \\
\text { all relevant bodies with nexus to AML/CFT supervision have been } \\
\text { circulated to and discussed with each body. The relevant statistics } \\
\text { are to be provided periodically (mainly on an annual basis) to the } \\
\text { FSC which serves as the repository for such statistical data which } \\
\text { are expected to be discussed and analyzed at the level of the Inter- } \\
\text { governmental Committee on AML/CFT. The collection of such } \\
\text { statistics should aid in the development of proper statistical data and } \\
\text { allow for more meaningful analysis of this data. }\end{array}$ \\
\hline & \\
\hline \multicolumn{2}{|r|}{ 2. Preventive Measures: Financial Institutions } \\
\hline $\begin{array}{l}\text { Risk of money laundering or } \\
\text { terrorist financing }\end{array}$ & \\
\hline $\begin{array}{l}\text { Customer due diligence, } \\
\text { including enhanced or reduced } \\
\text { measures } \\
\text { R. } 5 \text { - PC } \\
\text { R. } 6 \text { - LC } \\
\text { R. } 7 \text { - LC } \\
\text { R. } 8 \text { - PC }\end{array}$ & $\begin{array}{l}\text { - The requirement for financial institutions to verify that any } \\
\text { person purporting to act on behalf of customers that are legal } \\
\text { persons or legal arrangements is so authorized, and identify } \\
\text { and verify the identity of that person should be legislated. } \\
\text { Section 19(3) of the Anti-money Laundering and Terrorist Financing } \\
\text { Code of Practice, (AMLTFCOP) has been amended to require an } \\
\text { entity or professional: } \\
\text { "to enquire into and identify a person who purports to act on behalf } \\
\text { of an applicant for business or a customer, which is a legal person or } \\
\text { a partnership, trust or other legal arrangement, is so authorised and } \\
\text { to verify the person's identity." } \\
\text { The amendment is dealt with under the Anti-money Laundering and } \\
\text { Terrorist Financing (Amendment) Code of Practice, } 2009 \text { which was }\end{array}$ \\
\hline
\end{tabular}


enacted in January, 2009.

> Section 19(6) of the AMLTFCOP has been amended to allow entities to apply simplified or reduced CDD measures where:

"the applicants for business or customers are resident in foreign jurisdictions which the Commission is satisfied are in compliance with and effectively implement the FATF Recommendations pursuant to the provisions of section 52 ;

in the case of a body corporate that is part of a group, the body corporate is subject to and properly and adequately supervised for compliance with antimoney laundering and terrorist financing requirements that are consistent with the FATF Recommendations."

- The authorities should issue a list of jurisdictions that they recognize as having in place measures implementing FATF Recommendations to allow financial institutions to apply simplified or reduced CDD measures to customers resident in those countries.

$>$ Section 52(2) of the AMLTFCOP provides the legal framework for the listing of recognized jurisdictions as laid out in Schedule 2 of the AMLTFCOP. This relates to jurisdictions

"(a) which apply the FATF Recommendations and which the Commission considers, for the purposes of subsection (1), apply or sufficiently apply those Recommendations; and (b) whose anti-money laundering and terrorist financing laws are equivalent with the provisions of the Anti-money Laundering Regulations, 2008 and this Code."

$>\quad$ The amendment is dealt with under the Anti-money Laundering and Terrorist Financing (Amendment) Code of Practice, 2009 which was enacted in January, 2009.

- The requirement for entities and professionals to adopt relevant risk management processes and procedures for permitting a business relationship before effecting the necessary verification should be enforceable.

$>$ Section 23(2) of the AMLTFCOP has been amended to allow an entity or professional to complete verification after the establishment of a business relationship on the condition that:

(b) prior to the establishment of the business relationship, the entity or professional adopts appropriate risk management processes and procedures, having regard to the context and circumstances in which the business relationship is being developed; and

(c) following the establishment of the business relationship, the money laundering or terrorist financing risks that may be associated with the business relationship are properly and effectively monitored and managed." 


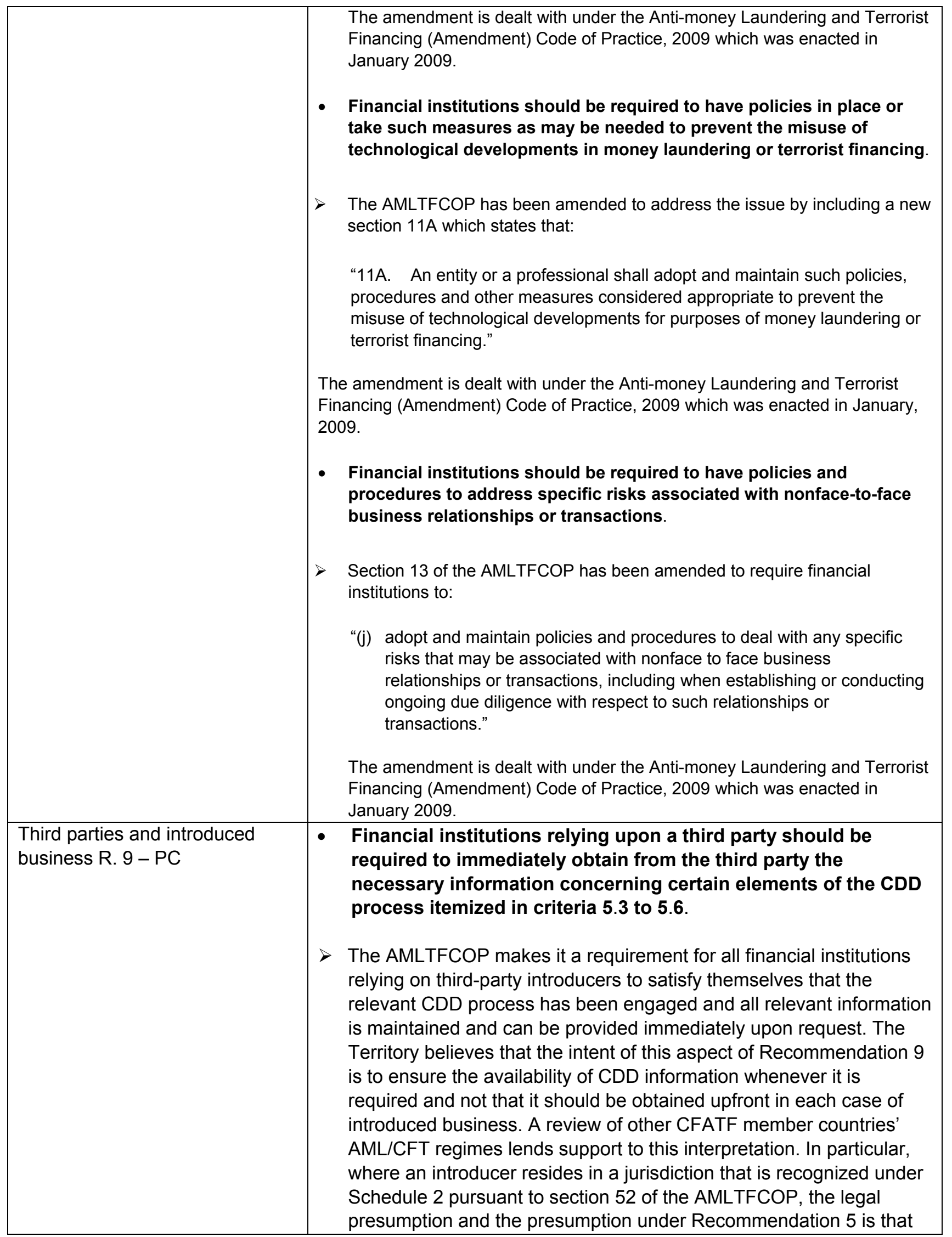




\begin{tabular}{|c|c|c|}
\hline & & $\begin{array}{l}\text { the introducer would be properly and effectively monitored for } \\
\text { AML/CFT compliance (including the carrying out of relevant CDD } \\
\text { actions) in that recognized jurisdiction such that it does not } \\
\text { synchronize with logic that CDD information should be immediately } \\
\text { required from the same introducer. With regard to introductions from } \\
\text { nonrecognized jurisdictions, the requirement is that all financial } \\
\text { institutions must obtain the required CDD information before or at the } \\
\text { time of accepting the introduced business; there is no exception in } \\
\text { that regard. } \\
\text { [The BVI also notes that there are issues globally relating to the } \\
\text { actual meaning and scope of this aspect of Recommendation } 9 \\
\text { which explains the reason there is currently an FATF Working Group } \\
\text { tasked with the responsibility of reviewing the Recommendation.] }\end{array}$ \\
\hline $\begin{array}{l}\text { Financial institution secrecy or } \\
\text { confidentiality R. } 4 \text { - C }\end{array}$ & & \\
\hline $\begin{array}{l}\text { Record keeping and wire } \\
\text { transfer rules } \\
\text { R. } 10-\text { LC } \\
\text { SR. VII - LC }\end{array}$ & $>$ & $\begin{array}{l}\text { The AMLTFCOP should be amended to remove the possibility of } \\
\text { identification data being destroyed five years after the last } \\
\text { transaction of an account that has not been formally terminated. } \\
\text { Section } 44 \text { and } 45 \text { of the AMLTFCOP have been amended to } \\
\text { remove the possibility of identification data being destroyed five } \\
\text { years after the last transaction of an account that has not been } \\
\text { formally terminated. } \\
\text { Account files and business correspondence should be } \\
\text { maintained for at least five years following the termination of an } \\
\text { account or business relationship. } \\
\text { The Anti-money Laundering (Amendment) Regulations have been } \\
\text { drafted to delete paragraph } 10 \text { (1) (c) which allowed the maintaining } \\
\text { of records for a period of five years from the time "when the last } \\
\text { transaction was carried out". The determining period under the } \\
\text { amendment now relates only to the time when the established } \\
\text { business relationship was formally ended, which complies with the } \\
\text { Examiners' recommended action. This amendment is expected to be } \\
\text { enacted before the next CFATF Plenary in } 2010 \text {. } \\
\text { Penalties and sanctions applicable for obligations of SR. VII in } \\
\text { sections } 37 \text { to } 47 \text { of the AMLTFCOP should be dissuasive. } \\
\text { - } \\
\text { The PCCA has been amended to stiffen the penalties for: } \\
\text { contravening provisions of the AMLTFCOP; } \\
\text { conduct; }\end{array}$ \\
\hline
\end{tabular}




\begin{tabular}{|c|c|}
\hline & 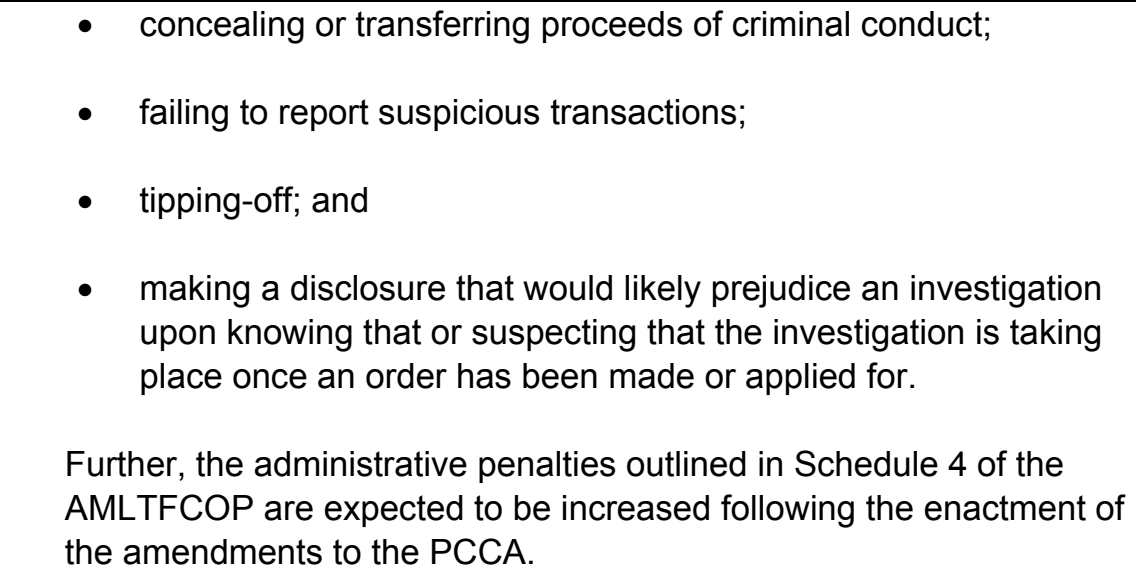 \\
\hline $\begin{array}{l}\text { Monitoring of transactions and } \\
\text { relationships } \\
\text { R. } 11-\text { PC } \\
\text { R. } 21-\text { PC }\end{array}$ & $\begin{array}{l}\text { - Financial institutions should be required to examine as far as } \\
\text { possible the background and purpose of complex, unusual large } \\
\text { transactions or unusual patterns of transactions that have no } \\
\text { apparent or visible economic or lawful purpose and to set forth } \\
\text { their findings in writing. } \\
\text { Section } 13 \text { of the AMLTFCOP has been amended to require that an } \\
\text { entity or professional exercise constant vigilance in its dealings with } \\
\text { an applicant for business or a customer and requires the entity or } \\
\text { professional to: } \\
\text { "(h) identify and pay special attention to, and examine, as far as } \\
\text { possible, the background and purpose of, any complex or unusual } \\
\text { large or unusual pattern of transaction or transaction that does not } \\
\text { demonstrate any apparent or visible economic or lawful purpose or } \\
\text { which is unusual having regard to the pattern of business or known } \\
\text { sources of an applicant for business or a customer." } \\
\text { Financial institutions should be required to keep such findings } \\
\text { available for competent authorities and auditors for at least five } \\
\text { years. } \\
\text { Section } 13 \text { of the AMLTFCOP has also been amended to require an } \\
\text { entity or professional to: } \\
\text { "(i) record its or his findings in relation to any examination carried } \\
\text { out pursuant to paragraph (h) and make such findings available to } \\
\text { the Agency, Commission or other lawful authority, including the } \\
\text { auditors of the entity or professional, for a period of at least five } \\
\text { years; and } \\
\text { adopt and maintain policies and procedures to deal with any specific } \\
\text { risks that may be associated with nonface to face business } \\
\text { relationships or transactions, including when establishing or } \\
\text { conducting ongoing due diligence with respect to such relationships } \\
\text { or transactions." }\end{array}$ \\
\hline
\end{tabular}




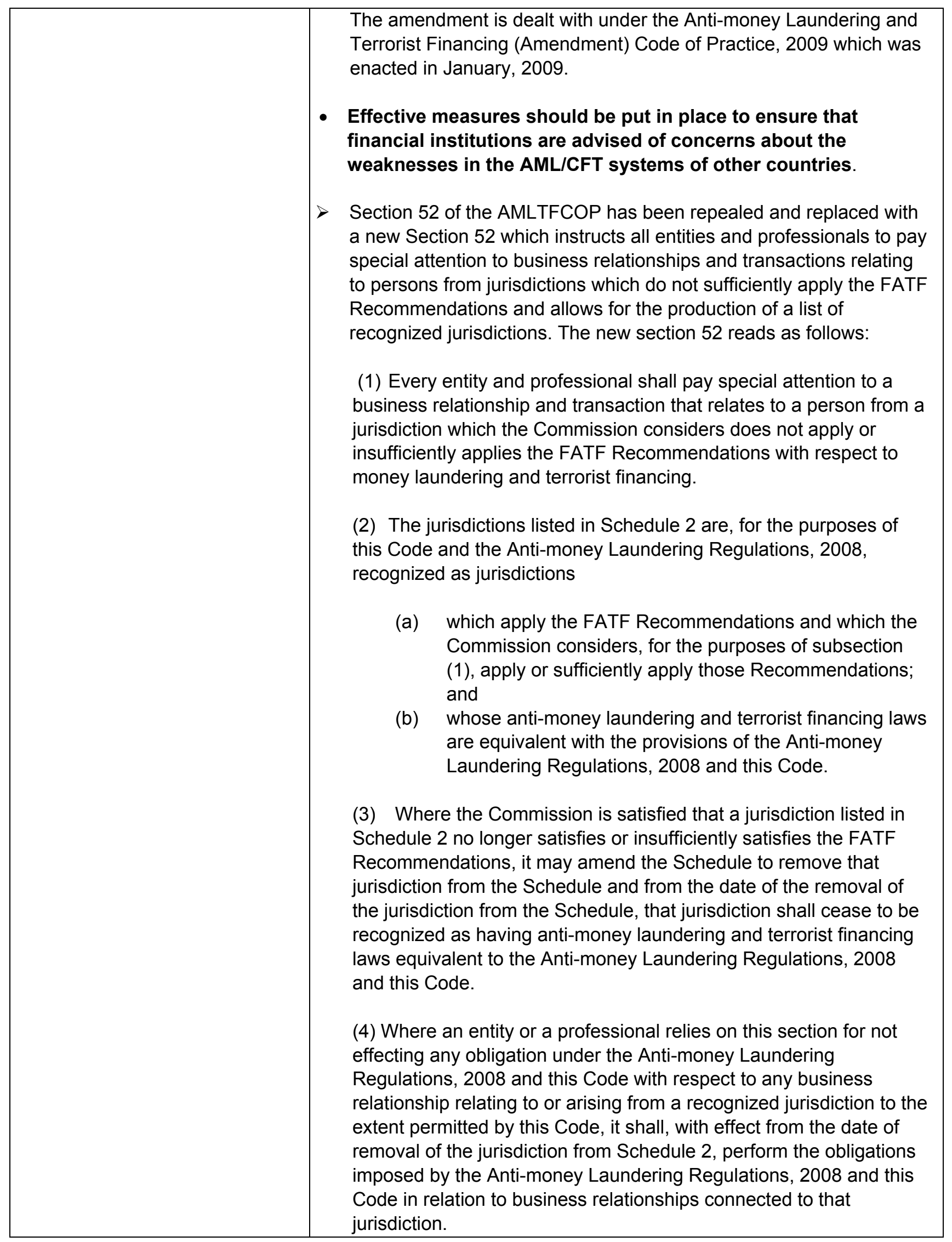


(5) The Commission may from time to time

(a) issue advisory warnings to entities and professionals pursuant to the Financial Services Commission Act, 2001 or this Code, advising entities and professionals of weaknesses in the anti-money laundering and terrorist financing systems of other jurisdictions;

(a) amend Schedule 2, and every amendment of the Schedule shall be published in the Gazette."

- The background and purpose of transactions with no apparent economic or visible lawful purpose from countries which do not or insufficiently apply the FATF Recommendations should be examined and the written findings made available to assist competent authorities and auditors.

$>$ Section 13(2) of the AMLTFCOP has been amended to require entities or professionals to exercise constant vigilance in their dealings with applicants for business or customers, and to:

"(h) identify and pay special attention to, and examine, as far as possible, the background and purpose of, any complex or unusual large or unusual pattern of transaction or transaction that does not demonstrate any apparent or visible economic or lawful purpose or which is unusual having regard to the pattern of business or known sources of an applicant for business or a customer;

(i) record its or his findings in relation to any examination carried out pursuant to paragraph $(\mathrm{h})$ and make such findings available to the Agency, Commission or other lawful authority, including the auditors of the entity or professional, for a period of at least five years;"

The amendments are dealt with under the Anti-money Laundering and Terrorist Financing (Amendment) Code of Practice, 2009 which was enacted in January, 2009.

Suspicious transaction reports and other reporting

R. 13 - LC

R. $14-$ LC

R. $19-\mathrm{C}$

R. $25-$ LC

SR. IV $-\mathrm{C}$
- The FIA annual reports should include the results of disclosure and information on typologies.

FIA Annual Report now contains details on results of disclosures and information on typologies.

- Enact legislation criminalizing insider trading and market manipulation as predicate offences for money laundering.

> The criminalization of insider trading and market manipulation as addressed in sections 88 and 91 respectively of the Securities and Investment Business Act, (SIBA) makes them predicate offenses for 


\begin{tabular}{|c|c|}
\hline & $\begin{array}{l}\text { money laundering. The penalties for such acts are also outlined in } \\
\text { these sections of the Act. SIBA had its } 1 \text { st Reading on March 18, } \\
2010 \text { and is awaiting final legislative approval (set for March 12, } \\
2010 \text { ). } \\
\text { - The tipping off offence should be extended to include } \\
\text { disclosure of the fact that a STR or related information is being } \\
\text { reported or provided to the FIA. } \\
\text { The Proceeds of Criminal Conduct Act, } 1997 \text { (PCCA) has been } \\
\text { amended to extend the offence of tipping off to include disclosure of } \\
\text { the fact that a STR or related information is being reported or } \\
\text { provided to the FIA. Section } 31 \text { (2) (a) of the Act now reads: } \\
\text { "(2) A person commits an offence if he knows or suspects that a } \\
\text { disclosure ("the disclosure") is being or has been made to the Reporting } \\
\text { Authority under section } 28 \text { or } 29 \text {;" } \\
\text { The amendment is dealt with under the Proceeds of Criminal Conduct } \\
\text { (Amendment) Act, } 2010 \text { which was enacted in February } 2010 \text {. }\end{array}$ \\
\hline $\begin{array}{l}\text { Internal controls, compliance, } \\
\text { audit and foreign branches } \\
\text { R. } 15-\text { PC } \\
\text { R. } 22-\text { PC }\end{array}$ & $\begin{array}{l}\text { - Financial institutions should be required to maintain an } \\
\text { adequately resourced and independent audit function to test } \\
\text { compliance with AML/CFT procedures, policies and controls. } \\
\text { Section } 11 \text { of the AMLTFCOP has been amended by including a } \\
\text { new sub-section (3A) which requires that: } \\
\text { "(3A) Every entity and professional shall establish and maintain an } \\
\text { independent audit function that is adequately resourced to test } \\
\text { compliance, including sample testing, with its or his written system } \\
\text { of internal controls and the other provisions of the Anti-money } \\
\text { Laundering Regulations, } 2008 \text { and this Code." } \\
\text { The amendment is dealt with under the Anti-money Laundering and } \\
\text { Terrorist Financing (Amendment) Code of Practice, } 2009 \text { which was } \\
\text { enacted in January, } 2009 \text {. } \\
\text { Financial institutions should be required to pay particular } \\
\text { attention that consistent AML/CFT measures are observed with } \\
\text { respect to their branches and subsidiaries in countries which } \\
\text { do not or insufficiently apply the FATF Recommendations. } \\
\text { Section } 53 \text { of the AMLTFCOP has been amended by inserting } \\
\text { subsection (1A) to require that financial institutions pay particular } \\
\text { attention that consistent AML/CFT measures are observed with } \\
\text { respect to their branches and subsidiaries in countries which do not } \\
\text { sufficiently apply the FATF Recommendations: The subsection reads } \\
\text { as follows: }\end{array}$ \\
\hline
\end{tabular}




\begin{tabular}{|c|c|}
\hline & $\begin{array}{l}\text { "(1A) entity shall, in particular, ensure that the requirement of } \\
\text { subsection (1) is observed by its branches, subsidiaries or } \\
\text { representative offices that operate in foreign jurisdictions which do } \\
\text { not or which insufficiently apply anti-money laundering and terrorist } \\
\text { financing standards equivalent to those of the Anti-money } \\
\text { Laundering Regulations, } 2008 \text { and this Code." } \\
\text { - Financial institutions should be required to inform their home } \\
\text { country supervisor when a foreign branch or subsidiary is } \\
\text { unable to observe appropriate AML/CFT measures because this } \\
\text { is prohibited by local laws, regulations or other measures. } \\
\text { Section } 53 \text { of the AMLTFCOP has been further amended by } \\
\text { inserting subsections (3A) and (3B) to require that financial } \\
\text { institutions inform their home country supervisor that a foreign } \\
\text { branch is unable to observe appropriate AML/CFT measures } \\
\text { because of prohibition by local laws, regulations and other } \\
\text { measures: The subsections read as follows: } \\
\text { "(3A) An entity that has branches, subsidiaries or representative } \\
\text { offices operating in foreign jurisdictions shall notify the Agency } \\
\text { and the Commission in writing if any of the entity's branches, } \\
\text { subsidiaries or representative offices is unable to observe } \\
\text { appropriate anti-money laundering and terrorist financing } \\
\text { measures on account of the fact that such observance is } \\
\text { prohibited by the laws, policies or other measures of the foreign } \\
\text { jurisdiction in which it operates. }\end{array}$ \\
\hline & $\begin{array}{l}\text { (3B) Where a notification is provided pursuant to subsection } \\
\text { (3A), } \\
\text { (a) the entity concerned may consider the desirability of } \\
\text { continuing the operation of the branch, subsidiary or } \\
\text { representative office in the foreign jurisdiction and act } \\
\text { accordingly; and } \\
\text { (b) the Agency and the Commission shall liaise and } \\
\text { consider what steps, if any, need to be adopted to properly } \\
\text { and efficiently deal with the notification, including the need } \\
\text { or otherwise of providing necessary advice to the entity } \\
\text { concerned." } \\
\text { The amendments are dealt with under the Anti-money Laundering and } \\
\text { Terrorist Financing (Amendment) Code of Practice, } 2009 \text { which was } \\
\text { enacted in January, } 2009 \text {. }\end{array}$ \\
\hline $\begin{array}{l}\text { Shell banks } \\
\text { R. } 18-C\end{array}$ & \\
\hline $\begin{array}{l}\text { Supervisory and oversight } \\
\text { system-competent authorities } \\
\text { and SROs } \\
\text { Role, functions, duties and }\end{array}$ & $\begin{array}{l}\text { - Review sanctions imposed in the AMLR and the AMLFTCOP } \\
\text { with a view to making them dissuasive. }\end{array}$ \\
\hline
\end{tabular}




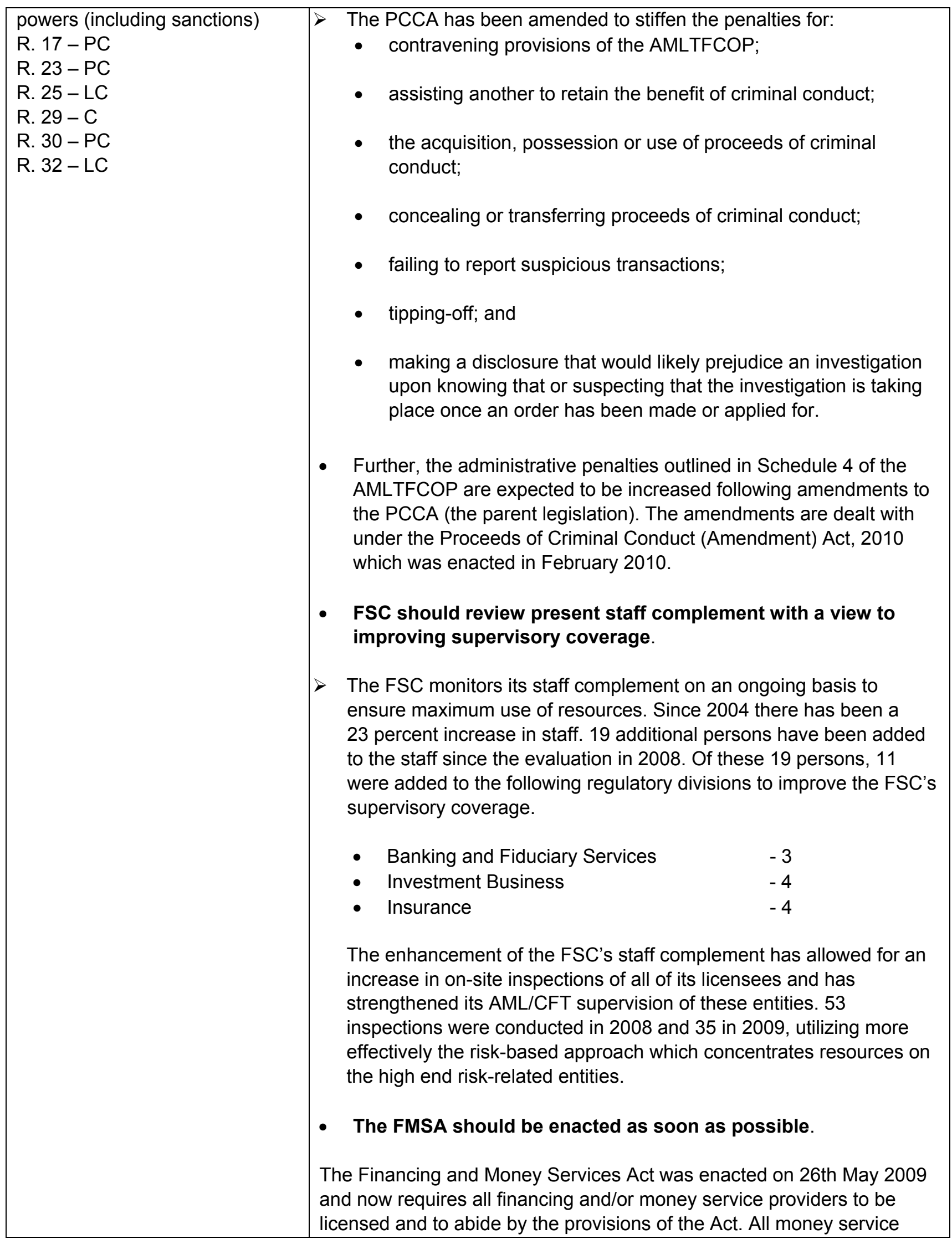




\begin{tabular}{|c|c|}
\hline & providers are now under the regulatory supervision of the FSC. \\
\hline $\begin{array}{l}\text { Money value transfer services } \\
\text { SR. } \mathrm{VI}-\mathrm{NC}\end{array}$ & $\begin{array}{l}\text { - The FMSA should be enacted as soon as possible. } \\
\text { The Financing and Money Services Act was enacted on 26th May } \\
2009 \text { and now requires all financing and/or money service providers } \\
\text { to be licensed and to abide by the provisions of the Act. All money } \\
\text { service providers are now under the regulatory supervision of the } \\
\text { FSC. }\end{array}$ \\
\hline \multicolumn{2}{|c|}{ 3. Preventive Measures: Nonfinancial Businesses and Professions } \\
\hline $\begin{array}{l}\text { Customer due diligence and } \\
\text { record-keeping } \\
\text { R. } 12-\text { PC }\end{array}$ & $\begin{array}{l}\text { - Deficiencies identified for all entities and professionals as noted } \\
\text { for Recs. 5, 6, 8-11, in the relevant sections of this report are also } \\
\text { applicable to DNFBPs. Implementation of the specific } \\
\text { recommendations in the relevant sections of this report will also } \\
\text { apply to DNFBPs. } \\
\\
\text { See relevant changes made in respect of Recs } 5,6,8-11 \text {. }\end{array}$ \\
\hline $\begin{array}{l}\text { Suspicious transaction reporting } \\
\text { R. } 16-P C\end{array}$ & $\begin{array}{l}\text { - Deficiencies identified with regard to Recs. } 13 \text { to } 15 \text {, and } 21 \text { are } \\
\text { also applicable to DNFBPs. Implementation of the specific } \\
\text { recommendations in the relevant sections of this report will also } \\
\text { apply to DNFBPs. } \\
\\
\text { See relevant changes made in respect of Recs. } 13-15 \text { and } 21 \text {. }\end{array}$ \\
\hline $\begin{array}{l}\text { Regulation, supervision, } \\
\text { monitoring, and sanctions } \\
\text { R. } 24-\text { PC } \\
\text { R. } 25 \text { - LC }\end{array}$ & $\begin{array}{l}\text { - Effective systems for monitoring and ensuring compliance with } \\
\text { AML/CFT requirements by real estate agents, lawyers, other } \\
\text { independent legal advisers, accountants and dealers in precious } \\
\text { metals and stones should be implemented. } \\
\text { JALTFAC has now been tasked with the responsibility of reviewing } \\
\text { the current AML/CFT supervisory regime in place and recommend a } \\
\text { way forward as to how best real estate agents, lawyers, accountants } \\
\text { and dealers in precious metals and stones may be dealt with in } \\
\text { relation to their supervision for AML/CFT compliance. The } \\
\text { independent professionals currently fall under the purview of the FIA } \\
\text { by virtue of section } 9 \text { (2) of the AMLTFCOP, but the current plan } \\
\text { seeks to explore the effectiveness of the current arrangement in order } \\
\text { to ensure full monitoring and supervision of these independent } \\
\text { advisers. This process is ongoing. } \\
\text { - Deficiencies identified regarding sanctions and sufficient } \\
\text { resources for the FSC should be remedied. } \\
\text { See relevant changes made in relation to Recs. } 17 \text { \& } 23 \text {. }\end{array}$ \\
\hline \multicolumn{2}{|l|}{$\begin{array}{l}\text { Other designated nonfinancial } \\
\text { businesses and professions } \\
\text { R. } 20-C\end{array}$} \\
\hline \multicolumn{2}{|c|}{ 4. Legal Persons and Arrangements \& Nonprofit Organizations } \\
\hline $\begin{array}{l}\text { Legal Persons-Access to } \\
\text { beneficial ownership and control } \\
\text { information } \\
\text { R. } 33 \text {-PC }\end{array}$ & $\begin{array}{l}\text { - The FSC should implement an effective monitoring system to } \\
\text { ensure that registered agents are maintaining adequate accurate } \\
\text { and current beneficial ownership information. }\end{array}$ \\
\hline
\end{tabular}




\begin{tabular}{|c|c|}
\hline & $\begin{array}{l}\text { The FSC's on-site inspection program is a risk-based program which } \\
\text { ranks entities based on their risk profile. Entities with a higher risk } \\
\text { rating are subject to more frequent inspections than those with a } \\
\text { lower rating. During such inspections all necessary action is taken to } \\
\text { ensure that these entities are maintaining adequate and current } \\
\text { beneficial ownership information. Such action includes a process of } \\
\text { sampling files to establish whether registered agents are indeed } \\
\text { maintaining adequate and current information on beneficial } \\
\text { ownership. The enhancement of the FSC's staff complement has } \\
\text { allowed for an increase in the number of on-site inspections. In } 2008 \text {, } \\
\text { the FSC conducted } 53 \text { on-site inspections and there were } \\
35 \text { inspections conducted in } 2009 \text {, utilizing more effectively the risk- } \\
\text { based approach which concentrates resources on the high end risk- } \\
\text { related entities. }\end{array}$ \\
\hline $\begin{array}{l}\text { Legal Arrangements-Access to } \\
\text { beneficial ownership and control } \\
\text { information R. } 34 \text { - LC }\end{array}$ & \\
\hline $\begin{array}{l}\text { Nonprofit organizations } \\
\text { SR. VIII - PC }\end{array}$ & $\begin{array}{l}\text { The authorities should review the adequacy of the laws that } \\
\text { relate to NPOs and conduct periodic reassessment of the } \\
\text { sector's potential vulnerabilities to terrorist activities. } \\
\text { The AMLTFCOP has been amended to insert a new section 4A to } \\
\text { comprehensively deal with charities and other nonprofit making } \\
\text { institutions, associations or organizations in the application of the } \\
\text { AMLTFCOP. The new section provides the following: } \\
\text { "4A.(1) The provisions of this Code relating to the establishment of } \\
\text { internal control systems, effecting customer due diligence } \\
\text { measures, maintaining record keeping requirements and } \\
\text { providing employee training shall apply to every charity or other } \\
\text { association not for profit which: } \\
\text { (a) is established and carries on its business in or from } \\
\text { within the Virgin Islands; } \\
\text { (b) is established outside the Virgin Islands and registered } \\
\text { to carry on its business wholly or partly in or from within } \\
\text { the Virgin Islands; or } \\
\text { (c) is established as provided in paragraph (a) and receives } \\
\text { or makes payments, other than salaries, wages, } \\
\text { pensions and gratuities, in excess of ten thousand } \\
\text { dollars in a year. } \\
\text { (2) A charity or other association not for profit shall: } \\
\text { (a) comply with the provisions outlined in subsection (1) in } \\
\text { relation to every donor to the charity or other association } \\
\text { not for profit of monies or equivalent assets in excess of } \\
\text { ten thousand dollars; } \\
\text { (a) }\end{array}$ \\
\hline
\end{tabular}


(b) maintain relevant documentation with respect to its administrative, managerial and policy control measures in relation to its operations;

(c) ensure that any funds that are planned and advertised by or on behalf of the charity or other association not for profit are verified as having been planned and spent in the manner indicated; and

(d) adopt such measure as are considered appropriate to ensure that any funds or other assets that are received, maintained or transferred by or through the charity or other association not for profit are not for, or diverted to support,

(i) the activities of any terrorist, terrorist organization or other organized criminal group; or

(ii) any money laundering activity.

(3) For the purposes of subsection (2), where a series of donations from a single donor appear to be linked and cumulatively the donations are in excess of ten thousand dollars in any particular year, the requirements outlined in subsection (1) shall apply.

(4) Subsection (1) (c) does not apply where payment is made for goods or services the total of which do not in any particular year exceed twenty-five thousand dollars or its equivalent in any currency.

(5) Where a person who makes a donation (whether in cash or otherwise in excess of the amount or its equivalent stipulated in this section) does not wish to have his name publicly revealed, the charity or other association not for profit that receives the donation shall nevertheless carry out the requisite customer due diligence and record keeping measures under this Code, including:

(a)establishing the nature and purpose of the donation;

(b) identifying whether or not there are any conditions attached to the donation and, if so, what those conditions are;

(c) identifying the true source of the donation and whether or not the donation is commensurate with the donor's known sources of funds or wealth; 


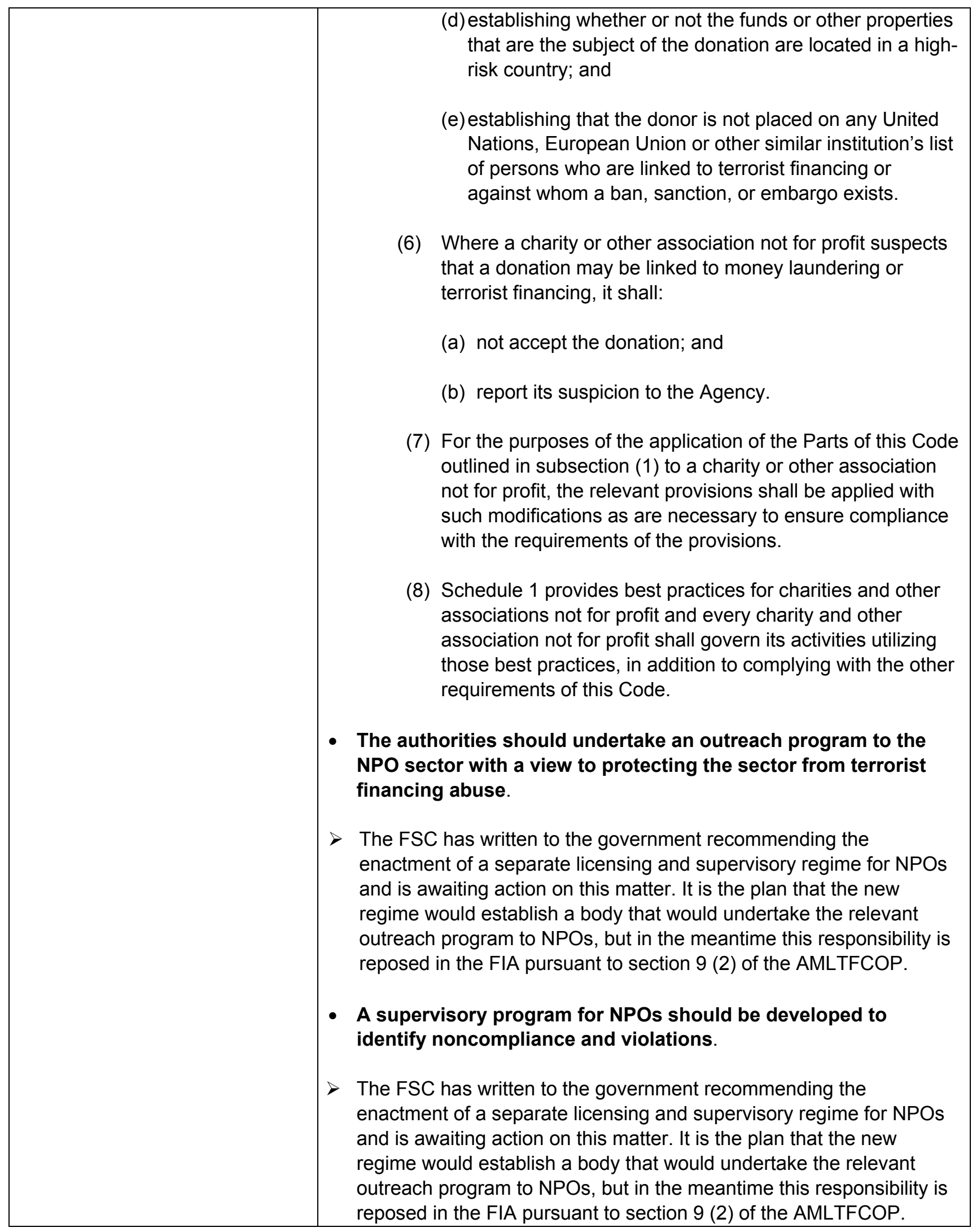




\begin{tabular}{|c|c|}
\hline \multicolumn{2}{|r|}{ 5. National and International Cooperation } \\
\hline $\begin{array}{l}\text { National cooperation and } \\
\text { coordination R. } 31 \text { - C; } \\
\text { R. } 32 \text { - LC }\end{array}$ & \\
\hline $\begin{array}{l}\text { The Conventions and UN } \\
\text { Special Resolutions } \\
\text { R. } 35 \text { - LC } \\
\text { SR. I - LC }\end{array}$ & $\begin{array}{l}\text { Since these laws have now been implemented locally active } \\
\text { efforts should be made to the United Kingdom to have the } \\
\text { Conventions extended to the Territory and provisions put in } \\
\text { place for the denial of landing of any aircraft used on behalf of } \\
\text { the Taliban and denial of safe haven in accordance with United } \\
\text { Nations Security Council Resolution } 1373 \text {. } \\
\text { The issue of extending the Conventions to the Territory has been } \\
\text { approved by the government; it has also been discussed with the UK } \\
\text { authorities and recommendations made for extending the said } \\
\text { Conventions to the Territory. Additionally, the Territory has fully } \\
\text { implemented S/RES/1373(2001) and S/RES/1267(1999) through the } \\
\text { passage of the Terrorism (United Nations Measures) (Overseas } \\
\text { Territories) Order, } 2001 \text { and the Anti-terrorism (Financial and Other } \\
\text { Measures) (Overseas Territories) Order, 2002). }\end{array}$ \\
\hline $\begin{array}{l}\text { Mutual Legal Assistance } \\
\text { R. } 36-C \\
\text { R. } 37-C \\
\text { R. } 38-C \\
\text { SR. V -C } \\
\text { R. } 32-\text { LC }\end{array}$ & \\
\hline $\begin{array}{l}\text { Extradition } \\
\text { R. } 39-C \\
\text { R. } 37-C \\
\text { SR.V - C } \\
\text { R. } 32-\text { LC }\end{array}$ & \\
\hline $\begin{array}{l}\text { Other Forms of Cooperation } \\
\text { R. } 40-C \\
\text { SR. V - C } \\
\text { R. } 32-\text { LC }\end{array}$ & \\
\hline \multicolumn{2}{|r|}{ 6. Other Issues } \\
\hline $\begin{array}{l}\text { Other relevant AML/CFT } \\
\text { measures or issues }\end{array}$ & \\
\hline $\begin{array}{l}\text { General framework - structural } \\
\text { issues }\end{array}$ & \\
\hline
\end{tabular}




\section{Appendix I. Financial Soundness Indicators}

\section{Table 15. British Virgin Islands: Financial Soundness Indicators for the Banking Sector-Commercial Banks (only)}

(In percent, unless otherwise indicated)

\begin{tabular}{|c|c|c|c|c|c|}
\hline Capital Adequacy & 2005 & 2006 & 2007 & 2008 & 2009 \\
\hline $\begin{array}{l}\text { Regulatory capital to risk-weighted } \\
\text { assets }\end{array}$ & 20.37 & 22.11 & 25.33 & 28.91 & 30.11 \\
\hline Capital to assets & 10.56 & 11.46 & 11.87 & 14.02 & 15.40 \\
\hline \multicolumn{6}{|l|}{ Asset quality } \\
\hline Nonperforming loans to total loans & 2.56 & 2.42 & 2.80 & 2.89 & 2.96 \\
\hline $\begin{array}{l}\text { Loan-loss provision to nonperforming } \\
\text { loans }\end{array}$ & $225.031 /$ & $137.572 /$ & 3.84 & 7.10 & 7.32 \\
\hline \multicolumn{6}{|l|}{ Earnings and profitability } \\
\hline Return on assets & 1.14 & 1.52 & 2.06 & 2.16 & 1.76 \\
\hline Return on equity & 32.81 & 36.40 & 28.76 & 28.93 & 23.31 \\
\hline Net interest income to gross income & 83.55 & 84.78 & 85.66 & 82.60 & 84.63 \\
\hline Noninterest expenses to gross income & 47.32 & 41.81 & 33.03 & 30.74 & 42.77 \\
\hline \multicolumn{6}{|l|}{ Liquidity } \\
\hline Liquid assets (in millions) & $1,204,929$ & 644,741 & $1,081,922$ & 873,465 & 927,411 \\
\hline Liquid assets to total assets & 31.35 & 30.41 & 26.45 & 29.32 & 24.71 \\
\hline $\begin{array}{l}\text { Liquid assets as a percentage of } \\
\text { deposits }\end{array}$ & 41.95 & 41.72 & 38.51 & 46.48 & 36.03 \\
\hline $\begin{array}{l}\text { Net open position in foreign exchange to } \\
\text { capital }\end{array}$ & $\mathrm{N} / \mathrm{A}$ & $\mathrm{N} / \mathrm{A}$ & N/A & $\mathrm{N} / \mathrm{A}$ & $\mathrm{N} / \mathrm{A}$ \\
\hline
\end{tabular}

Source. FSC.

$1 /$ This percentage is as a result of Bank $B$ reporting nonperforming loans of $\$ 78,000$ and loan-loss reserves of $\$ 401,000$, representing a loan-loss provision to nonperforming percentage of 514.10 percent; and Bank $C$ reporting nonperforming loans of $\$ 147,000$ and loan-loss reserves of $\$ 6.1$ million, representing a loan-loss provision to nonperforming percentage of 597.28 percent (causing an extraordinary spike in the overall average for that period).

$2 /$ This percentage is as a result of Bank B reporting Non-performing loans of $\$ 740,000$ and loan-loss reserves $\$ 5$ million, representing a loan loss provision to nonperforming percentage of 675.81 percent (causing an extraordinary hike in the overall average for that period). 


\section{Appendix II. Implementation of the Recommendations of the 2004 Assessment Report}

\begin{tabular}{|c|c|}
\hline 2004 Findings & Update \\
\hline $\begin{array}{l}\text { Executive Council not required to disclose } \\
\text { grounds for removal of Board members. }\end{array}$ & $\begin{array}{l}\text { FSCA s.9(2A) requires Cabinet (which replaced } \\
\text { Executive Council since 2007) to provide, in } \\
\text { writing, reasons for removal of Board members. } \\
\text { Amendment effected by FSC (Amendment) Act, } \\
2009 . \\
\text { Reasons for removal are not required to be } \\
\text { disclosed to the public. }\end{array}$ \\
\hline $\begin{array}{l}\text { Conflicts policy for FSC Board members could } \\
\text { be made more detailed and specific. }\end{array}$ & $\begin{array}{l}\text { The Board Code of Conduct has been reviewed } \\
\text { and revised to provide necessary details on } \\
\text { conflict of interest matters. Amendment approved } \\
\text { in March, } 2010 \text {. }\end{array}$ \\
\hline $\begin{array}{l}\text { MD does not have fixed-term appointment. } \\
\text { FSC Board not required to disclose grounds for } \\
\text { removal. }\end{array}$ & $\begin{array}{l}\text { Appointment of the MD is set based on agreed } \\
\text { terms and conditions in a private employment } \\
\text { contract. } \\
\text { FSCA s.10(1A) requires the Board to provide } \\
\text { written reason(s) for removal of MD. Amendment } \\
\text { effected by FSC (Amendment) Act, } 2009 \text {. } \\
\text { Reasons for removal of the MD are not required to } \\
\text { be disclosed to the public. }\end{array}$ \\
\hline $\begin{array}{l}\text { Vacancies in directorships of Legal Department, } \\
\text { Policy Planning Department, anticipated } \\
\text { vacancies in at least one other department. }\end{array}$ & $\begin{array}{l}\text { These posts were filled, there is no significant } \\
\text { senior post left open. }\end{array}$ \\
\hline $\begin{array}{l}\text { Need for additional trained regulatory staff. } \\
\text { Specialized consultants and/or requiring } \\
\text { external auditors not used to perform and certify } \\
\text { certain compliance testing. }\end{array}$ & $\begin{array}{l}\text { Additional regulatory staff has been added to each } \\
\text { regulatory division on a consistent basis over the } \\
\text { last five (5) years. } \\
\text { New staff receives training by various methods } \\
\text { both locally and overseas. } \\
\text { Consultants are retained used in relevant aspects } \\
\text { of the Commission's work - legislation, } \\
\text { compliance testing on standards, risk-based } \\
\text { assessment program development, etc. }\end{array}$ \\
\hline $\begin{array}{l}\text { Detailed reasons for all nonroutine decisions not } \\
\text { always provided unless requested. }\end{array}$ & $\begin{array}{l}\text { S.13 of the FSCA requires the Commission, in the } \\
\text { exercise of its powers, to give reasons in writing } \\
\text { for its decisions. Additionally, the Procedures and } \\
\text { Operating Guidelines of the LSC have been } \\
\text { revised and the EC guidelines amended to include }\end{array}$ \\
\hline
\end{tabular}




\begin{tabular}{|c|c|}
\hline & $\begin{array}{l}\text { the requirement to provide reasons for all } \\
\text { nonroutine decisions taken. Enforcement } \\
\text { decisions should be publicly disclosed. }\end{array}$ \\
\hline $\begin{array}{l}\text { No regular and comprehensive audit and } \\
\text { compliance program. } \\
\text { No on-site inspections. } \\
\text { No manual for inspections. }\end{array}$ & $\begin{array}{l}\text { A full inspections program has been in place since } \\
2004 \text { for most regulatory divisions, and from } 2008 \\
\text { for the investment business division. A KPMG } \\
\text { product, KReview, is used to guide the } \\
\text { examination staff through an on-site inspection. } \\
\text { KReview includes an electronic inspections } \\
\text { manual, with updates. } \\
\text { The } 2010 \text { inspection plan will be drawn up April } \\
2010 \text {. }\end{array}$ \\
\hline $\begin{array}{l}\text { Accounting standards for financial statements } \\
\text { not detailed; allowed to use home jurisdiction } \\
\text { standards. }\end{array}$ & $\begin{array}{l}\text { Division } 6 \text { of the Regulatory Code outlines the } \\
\text { recognized accounting and audit standards that } \\
\text { may be used by licensees in the preparation of } \\
\text { financial statements. Section 59. (1) states that "a } \\
\text { licensee shall ensure that its financial statements, } \\
\text { and any group accounts required to be submitted } \\
\text { to the Commission, are prepared in accordance } \\
\text { with } \\
\text { (a) one of the following international standards: } \\
\text { (i) the International Financial Reporting } \\
\text { Standards, promulgated by the } \\
\text { International Accounting Standards Board; } \\
\text { (ii) UK GAAP; } \\
\text { (iii) U. S. GAAP; or } \\
\text { (iv) Canadian GAAP; or } \\
\text { (b) such other recognized international accounting } \\
\text { standards as may be approved by the } \\
\text { Commission on a case-by-case basis. }\end{array}$ \\
\hline
\end{tabular}




\section{Table 16. Recommended Action Plan to Improve Observance of IAIS Insurance Core Principles}

\begin{tabular}{|c|c|c|}
\hline Reference Principle & 2004 Recommendation & Response \\
\hline \multicolumn{3}{|l|}{$\begin{array}{l}\text { Organization of an Insurance } \\
\text { Supervisor }\end{array}$} \\
\hline $\begin{array}{l}\text { CP 1. Legislation precludes the } \\
\text { FSC from receiving penalties that } \\
\text { are judicially determined. }\end{array}$ & $\begin{array}{l}\text { Consider making penalties } \\
\text { determined by the court as a } \\
\text { funding source for the FSC. }\end{array}$ & $\begin{array}{l}\text { FSCA s.62(1B) all administrative } \\
\text { penalties paid pursuant to the } \\
\text { Financial Services } \\
\text { (Administrative Penalties) } \\
\text { Regulations, } 2006 \text { to be collected } \\
\text { and retained by the Commission. } \\
\text { Similar provision is made in } \\
\text { section } 27 \text { (8) of the PCCA (2008 } \\
\text { amendment) and section } 57 \text { (3) } \\
\text { of the AMPLTFCOP of } 2008 \text {. }\end{array}$ \\
\hline \multicolumn{3}{|l|}{$\begin{array}{l}\text { Licensing and Changes in } \\
\text { Control }\end{array}$} \\
\hline $\begin{array}{l}\text { CP 2. There is not now a single } \\
\text { comprehensive compilation of all } \\
\text { licensing requirement. }\end{array}$ & $\begin{array}{l}\text { Compile a checklist of } \\
\text { licensing requirements once } \\
\text { the new Insurance Act has } \\
\text { been adopted. }\end{array}$ & $\begin{array}{l}\text { A checklist has been compiled as } \\
\text { part of the licensing section of } \\
\text { the Procedures Manual for use in } \\
\text { the Ins. Div. }\end{array}$ \\
\hline $\begin{array}{l}\text { CP 2. The FSCA provides for } \\
\text { formal Memoranda of } \\
\text { Understanding between BVI and } \\
\text { other jurisdictions, but does not } \\
\text { require that such an MOU be in } \\
\text { place as a prerequisite to granting } \\
\text { a license to an applicant licensed } \\
\text { in a foreign jurisdiction. }\end{array}$ & $\begin{array}{l}\text { Require that an MOU between } \\
\text { the BVI and the jurisdiction of } \\
\text { the applicant's domicile as a } \\
\text { prerequisite to application and } \\
\text { approval or that a "Certificate } \\
\text { of Good Standing" be executed } \\
\text { by the chief insurance } \\
\text { supervisory official of the } \\
\text { applicant's jurisdiction of } \\
\text { domicile. }\end{array}$ & $\begin{array}{l}\text { Without exception, the } \\
\text { Commission, requests the } \\
\text { opinion of the chief supervisor of } \\
\text { an applicant's jurisdiction on the } \\
\text { applicant's standing, such } \\
\text { opinion forms part of the } \\
\text { package presented to the LSC to } \\
\text { inform its decision on the } \\
\text { application. }\end{array}$ \\
\hline
\end{tabular}




\begin{tabular}{|c|c|c|}
\hline Reference Principle & 2004 Recommendation & Response \\
\hline $\begin{array}{l}\text { CP 3. While changes in control } \\
\text { are rare, the FSC obtains only } \\
\text { yearly information on controlling } \\
\text { persons. }\end{array}$ & $\begin{array}{l}\text { Issue a guidance note to } \\
\text { require immediate reporting of } \\
\text { any material changes in } \\
\text { ownership, control, or partial } \\
\text { control (for either the direct } \\
\text { parent of the captive or of the } \\
\text { "parent of the parent"). }\end{array}$ & $\begin{array}{l}\text { Sections } 21 \text { \& s. } 22 \text { of the } \\
\text { Insurance Act, } 2008 \text { (IA) } \\
\text { provides that any person owning } \\
\text { or holding a significant interest in } \\
\text { a BVI insurer shall not sell, } \\
\text { transfer, charge or otherwise } \\
\text { dispose of his interest, nor may a } \\
\text { person acquire a significant } \\
\text { interest in a BVI insurer without } \\
\text { prior written approval of the } \\
\text { Commission. A foreign insurer } \\
\text { must provide written notification } \\
\text { of any change in persons who } \\
\text { own or hold a significant interest, } \\
\text { within fourteen days of the } \\
\text { change. The Regulatory Code } \\
\text { (s. } 71(2) \text { ) requires all licensees to } \\
\text { immediately notify the } \\
\text { Commission of any change to } \\
\text { information or documentation } \\
\text { provided to the Commission } \\
\text { which may render it inaccurate, } \\
\text { including material changes in } \\
\text { ownership. }\end{array}$ \\
\hline \multicolumn{3}{|l|}{$\begin{array}{l}\text { Corporate Governance and } \\
\text { Internal Controls }\end{array}$} \\
\hline $\begin{array}{l}\text { CP } 4 \text { The nature of the business } \\
\text { of insurance in the BVI makes the } \\
\text { issue of corporate governance } \\
\text { one for which it will be difficult for } \\
\text { the FSC to maintain first-hand } \\
\text { and direct supervision of the } \\
\text { corporate governance standards } \\
\text { practiced by the industry. No } \\
\text { companies have a physical } \\
\text { presence in the BVI and captive } \\
\text { insurers are really individual risk- } \\
\text { transfer mechanism of each } \\
\text { founder's individual insurable } \\
\text { risks. However, the FSC does rely } \\
\text { on the corporate governance } \\
\text { standards applied by the country } \\
\text { of jurisdiction of the insurers that } \\
\text { write direct business in the BVI. }\end{array}$ & $\begin{array}{l}\text { Consider requiring insurance } \\
\text { managers to establish } \\
\text { corporate governance } \\
\text { standards both for the } \\
\text { manager's dealings with the } \\
\text { FSC and for its dealings with } \\
\text { the captive insurer itself. }\end{array}$ & $\begin{array}{l}\text { S. } 23 \text { thru s. } 26 \text { of the IA outline } \\
\text { the corporate governance } \\
\text { requirements for insurance } \\
\text { business licensees. S. } 83 \text { refers } \\
\text { to the general framework for } \\
\text { corporate governance to be } \\
\text { established under the RC, while } \\
\text { Part II, Division } 3 \text { ss. } 18 \text { thru } 24 \text { of } \\
\text { the RC outline this framework. } \\
\text { Part IV, Division } 2 \text { ss. } 140 \text { thru } \\
142 \text { of the RC cover corporate } \\
\text { governance issues specifically } \\
\text { related to Insurers. }\end{array}$ \\
\hline
\end{tabular}




\begin{tabular}{|c|c|c|}
\hline Reference Principle & 2004 Recommendation & Response \\
\hline $\begin{array}{l}\text { CP } 5 \text { As noted in the discussion } \\
\text { of CP } 4 \text { above, the situation in the } \\
\text { industry in the BVI does not easily } \\
\text { lend itself to strong standards of } \\
\text { internal control. However, the } \\
\text { FSC will be requiring the } \\
\text { insurance management firms to } \\
\text { have appropriate procedures for } \\
\text { management control of its } \\
\text { functions as the nexus between } \\
\text { the captive and the FSC, and } \\
\text { adhere to quality assurance } \\
\text { standards in performing its } \\
\text { function as the management of } \\
\text { the licensed entity. Additionally, } \\
\text { the insurance managers are likely } \\
\text { going to be filling the roles of } \\
\text { compliance officers. For this } \\
\text { reason, clear recordkeeping and } \\
\text { reporting requirements are critical. }\end{array}$ & $\begin{array}{l}\text { Adopt clear and unambiguous } \\
\text { requirements for recordkeeping } \\
\text { and reporting for the insurance } \\
\text { manager/compliance officer. }\end{array}$ & $\begin{array}{l}\text { S.38 of the RC covers the } \\
\text { requirement for maintenance of } \\
\text { adequate and orderly records } \\
\text { which shall be sufficient to enable } \\
\text { the Commission to monitor the } \\
\text { compliance of the licensee with } \\
\text { its regulatory obligations and its } \\
\text { AML/CFT obligations; and which } \\
\text { can be readily retrieved in BVI. }\end{array}$ \\
\hline \multicolumn{3}{|l|}{ Prudential Rules } \\
\hline $\begin{array}{l}\text { CP } 7 \text { Was this blank or does it } \\
\text { provide a summary of the CP? } \\
\text { Please check. }\end{array}$ & $\begin{array}{l}\text { Consider including test-checks } \\
\text { of particular insurers to } \\
\text { determine if greater detail for } \\
\text { internal (off-site) analysis } \\
\text { would be useful. }\end{array}$ & $\begin{array}{l}\text { When the off-site reviews are } \\
\text { being performed there is a } \\
\text { consideration as to whether or } \\
\text { not more information is needed } \\
\text { per company. This could be } \\
\text { company specific, triggered by } \\
\text { information submitted for the off- } \\
\text { site review, company specific } \\
\text { following market intelligence or } \\
\text { broader and thematic, following } \\
\text { information gathered from more } \\
\text { than one company's off-site, } \\
\text { indicating a trend into an area } \\
\text { that needs more investigation. } \\
\text { Themes that may have triggered } \\
\text { a deeper review in recent years } \\
\text { include CDOs in the asset list, to } \\
\text { check the quality and viability of } \\
\text { the wrap; and possible corporate } \\
\text { governance issues such as } \\
\text { failure to submit all "change } \\
\text { forms", and the like. }\end{array}$ \\
\hline
\end{tabular}




\begin{tabular}{|c|c|c|}
\hline Reference Principle & Recommended Action & Response \\
\hline $\begin{array}{l}\text { CP } 8 \text { Any summary of the } \\
\text { principle? }\end{array}$ & $\begin{array}{l}\text { Consider promulgating a formalized } \\
\text { dynamic set of risk-sensitive } \\
\text { performance indicators (indicators only } \\
\text { and not inflexible compulsory } \\
\text { benchmarks) based on study of the } \\
\text { models that will best fit the BVI market. } \\
\text { Make this freely available to insurers, } \\
\text { insurance managers, and compliance } \\
\text { officers. }\end{array}$ & $\begin{array}{l}\text { The Ins. Div. prepared a set of } \\
\text { seven performance indicators, } \\
\text { namely: } \\
\text { ((1) Net Loss Ratio; } \\
\text { (2) Expense Ratio; } \\
\text { (3) Net Earned Premiums } \\
\text { /Surplus; } \\
\text { (4) Change in Net Written } \\
\text { Premiums; } \\
\text { (5) Combined Ratio; } \\
\text { (6) Operating Profit/Net Earned } \\
\text { Premiums; and } \\
\text { (7) Operating Ratio. } \\
\text { These indicators are currently for } \\
\text { internal use only but consideration } \\
\text { is being given to making them } \\
\text { available to insurers, insurance } \\
\text { managers and compliance officers }\end{array}$ \\
\hline $\begin{array}{l}\text { CP } 9 \text { Although derivatives } \\
\text { are not currently available } \\
\text { in the BVI, a market might } \\
\text { develop in the future. }\end{array}$ & $\begin{array}{l}\text { Issue a guidance note dealing } \\
\text { specifically with permissible uses of } \\
\text { derivatives and the proper reporting } \\
\text { and accounting treatment. At the } \\
\text { beginning, derivatives could be issued } \\
\text { only for hedging particular assets or } \\
\text { liabilities, or classes of the same. }\end{array}$ & $\begin{array}{l}\text { The Insurance Act and Regulatory } \\
\text { Code set out permissible } \\
\text { derivatives and requires an insurer } \\
\text { to seek permission for any } \\
\text { instrument not specified. } \\
\text { Applications for a license must } \\
\text { include a business plan (including } \\
\text { investment strategy) and any } \\
\text { significant changes to that post- } \\
\text { licensing must be approved. }\end{array}$ \\
\hline \multicolumn{3}{|l|}{ Market Conduct } \\
\hline $\begin{array}{l}\text { CP 1. "Neither the nor } \\
\text { [words missing after } \\
\text { Neither...] the Insurance } \\
\text { Act contains precise } \\
\text { language governing unfair } \\
\text { trade practices, nor is there } \\
\text { any statutory scheme } \\
\text { proscribing unfair claim } \\
\text { settlement practices." }\end{array}$ & $\begin{array}{l}\text { Consider establishing requirements for } \\
\text { direct writing insurers to maintain } \\
\text { policyholder complaint logs that would } \\
\text { be made available to the FSC during } \\
\text { on-site inspections. Adopting standard } \\
\text { insurance contract coverage and unfair } \\
\text { trade practice and claim settlement } \\
\text { regulations should also be considered. }\end{array}$ & $\begin{array}{l}\text { Colonial Insurance (BVI) is the } \\
\text { only group that would be } \\
\text { considered a "direct writer"; } \\
\text { Under the Regulatory Code a } \\
\text { Compliance officer is required to } \\
\text { maintain procedures for the } \\
\text { monitoring and handling of } \\
\text { complaints, and to keep the } \\
\text { complaints procedures under } \\
\text { review; such procedures are } \\
\text { subject to review during an on- } \\
\text { site inspection. }\end{array}$ \\
\hline
\end{tabular}




\begin{tabular}{|c|c|c|}
\hline Reference Principle & Recommended Action & Response \\
\hline & & $\begin{array}{l}\text { The Regulatory Code provides that it is } \\
\text { the responsibility of the Board and senior } \\
\text { management of the regulated entity to } \\
\text { monitor market conduct activities. S. } 71 \text { of } \\
\text { the IA also provides that the licensee is } \\
\text { responsible for taking steps to protect its } \\
\text { customers and to ensure fair treatment at } \\
\text { all times. The powers of the Commission } \\
\text { to address false advertising by a licensee } \\
\text { are laid out in s.71(2) of the IA. }\end{array}$ \\
\hline \multicolumn{3}{|l|}{$\begin{array}{l}\text { Monitoring, Inspection, and } \\
\text { Sanctions }\end{array}$} \\
\hline $\begin{array}{l}\text { CP } 13 \text { There is no regular } \\
\text { program of on-site } \\
\text { inspections. }\end{array}$ & $\begin{array}{l}\text { Complete preparations of } \\
\text { manuals and training for on- } \\
\text { site inspections, and } \\
\text { implement plan for } \\
\text { inspections. }\end{array}$ & $\begin{array}{l}\text { An On-site Inspections Coordinator was } \\
\text { recruited in January 2007, and now } \\
\text { heads up the inspection team consisting } \\
\text { of regulators from each Division who } \\
\text { conduct the on-site inspections and } \\
\text { produce the inspection reports. The } \\
\text { procedures manual on inspections is also } \\
\text { applicable to the inspection of insurers. }\end{array}$ \\
\hline $\begin{array}{l}\text { CP } 14 \text { While the FSC has } \\
\text { broad authority to impose a } \\
\text { wide range of penalties; it does } \\
\text { not to impose money } \\
\text { penalties. }\end{array}$ & $\begin{array}{l}\text { Consider amending } \\
\text { legislation that would allow } \\
\text { levying of money penalties. }\end{array}$ & $\begin{array}{l}\text { S. } 56 \text { of the ( } 2009 \text { amendment) empowers } \\
\text { the Commission to compound an offence } \\
\text { by levying on offenders fines, which are } \\
\text { then collected and paid into the } \\
\text { Commission's bank account. In addition, } \\
\text { the Financial Services (Administrative } \\
\text { Penalties) Regulations, } 2006 \text { empower } \\
\text { the Commission to impose monetary } \\
\text { penalties for breaches of the regulatory } \\
\text { legislation, which are also paid into the } \\
\text { Commission's bank account. }\end{array}$ \\
\hline \multicolumn{3}{|l|}{$\begin{array}{l}\text { Cross-Border Operations, } \\
\text { Supervisory Coordination } \\
\text { and Cooperation, and } \\
\text { Confidentiality }\end{array}$} \\
\hline None & & \\
\hline
\end{tabular}


Table 17. Recommendations Related to the IOSCO Principles Assessment

\begin{tabular}{|c|c|c|}
\hline Reference Principle & Recommended Action & Updated Response \\
\hline Principle 2 & $\begin{array}{l}\text { Consider amending the legislation } \\
\text { to require the FSC to give reasons } \\
\text { for all nonroutine decisions even } \\
\text { when not requested. } \\
\text { Consider developing a more } \\
\text { detailed conflicts policy for Board } \\
\text { members. }\end{array}$ & $\begin{array}{l}\text { The FSCA requires the } \\
\text { Commission to provide written } \\
\text { reasons for its decisions. } \\
\text { Additionally, the LSC Guidelines } \\
\text { and Operating Procedures have } \\
\text { been revised and the EC } \\
\text { Guidelines and Operating } \\
\text { Procedures amended to include } \\
\text { the requirement to provide } \\
\text { reasons for all nonroutine } \\
\text { decisions taken. } \\
\text { The Board Code of Conduct } \\
\text { reviewed and revised to provide } \\
\text { necessary details on conflict of } \\
\text { interest matters. Amendment } \\
\text { approved in March, } 2010 \text {. }\end{array}$ \\
\hline Principle 3 & $\begin{array}{l}\text { Increase staff resources for } \\
\text { ongoing supervision and } \\
\text { enforcement. }\end{array}$ & $\begin{array}{l}\text { The Commission has increased } \\
\text { its resources available for } \\
\text { supervision and enforcement. } \\
\text { The Investment Business } \\
\text { Division currently has a staff } \\
\text { complement of } 13 \text { each of whom } \\
\text { is involved on various levels with } \\
\text { ongoing supervision and/or on- } \\
\text { site inspections. The Commission } \\
\text { has a dedicated inspection team } \\
\text { comprising an On-site Inspection } \\
\text { Coordinator and the EC carries } \\
\text { out enforcement activities. }\end{array}$ \\
\hline Principle 4 & $\begin{array}{l}\text { Make the detailed licensing and } \\
\text { approval processes and } \\
\text { requirements publicly available. } \\
\text { Enhance the breadth and the } \\
\text { transparency of the consultation } \\
\text { process. }\end{array}$ & $\begin{array}{l}\text { The Commission has published } \\
\text { on its website the Guidelines and } \\
\text { Operating Procedures of its } \\
\text { Licensing and Supervisory } \\
\text { Committee's procedure, which } \\
\text { set out the licensing approval } \\
\text { process. } \\
\text { The FSC Website makes } \\
\text { available all public information, } \\
\text { including legislation, regulations, } \\
\text { policy guidelines and forms. A } \\
\text { shortened form of the Public } \\
\text { Register is available on that site. } \\
\text { The Commission consults with a } \\
\text { variety of industry practitioner } \\
\text { groups, including the statutorily }\end{array}$ \\
\hline
\end{tabular}




\begin{tabular}{|c|c|c|}
\hline Reference Principle & Recommended Action & Updated Response \\
\hline & & $\begin{array}{l}\text { created consultative group, the } \\
\text { Mutual Funds Advisory } \\
\text { Committee. In addition, the } \\
\text { Commission consults with } \\
\text { various focus groups comprising } \\
\text { a broad cross section of industry } \\
\text { personnel. The Commission also } \\
\text { engages in town hall style public } \\
\text { consultation and makes draft } \\
\text { legislation available on its } \\
\text { website; as well as circulates } \\
\text { such documents to participants } \\
\text { on its mailing list, for their } \\
\text { comments and feedback. }\end{array}$ \\
\hline Principle 9 & $\begin{array}{l}\text { The fines that may be imposed } \\
\text { under the FSCA and Ensure that } \\
\text { sanctions are set at a level to be } \\
\text { an effective deterrent. }\end{array}$ & $\begin{array}{l}\text { Administrative penalties have } \\
\text { been increased through the } 2006 \\
\text { Financial Services } \\
\text { (Administrative Penalties) } \\
\text { Regulations (and amendments } \\
\text { thereto in 2007). The fines that } \\
\text { may be imposed under SIBA are } \\
\text { higher than those under the } \\
\text { FSCA. S.56 of the FSCA has } \\
\text { also been repealed and replaced } \\
\text { to empower the Commission to } \\
\text { impose a fine for an offence that } \\
\text { carries a penalty of a fine and for } \\
\text { which no criminal proceedings } \\
\text { have been instituted. Licensees } \\
\text { are subject to a broad range of } \\
\text { sanctions depending on the level } \\
\text { of the infraction. }\end{array}$ \\
\hline Principle 10 & $\begin{array}{l}\text { Take all necessary actions to } \\
\text { increase staff resources for } \\
\text { inspections and enforcement. } \\
\text { The completion and } \\
\text { implementation of the new audit } \\
\text { and compliance program should } \\
\text { also be expedited. }\end{array}$ & $\begin{array}{l}\text { The Commission has steadily } \\
\text { increased its resources available } \\
\text { for inspection and enforcement. } \\
\text { The Investment Business } \\
\text { Division currently has a staff } \\
\text { complement of } 13,1 / 3 \text { of whom } \\
\text { participate on various levels of } \\
\text { on-site inspections. In addition, } \\
\text { the Commission has since } 2009 \\
\text { established a dedicated } \\
\text { inspection team comprising the } \\
\text { On-site Inspection Coordinator } \\
\text { and } 4 \text { senior regulators from the } \\
\text { respective regulatory Divisions. } \\
\text { The Commission also has a } \\
\text { dedicated enforcement team in }\end{array}$ \\
\hline
\end{tabular}




\begin{tabular}{|c|c|c|}
\hline Reference Principle & Recommended Action & Updated Response \\
\hline & & $\begin{array}{l}\text { the Legal and Enforcement } \\
\text { Division that works in conjunction } \\
\text { with each regulatory Division as } \\
\text { the need arises. The EC takes } \\
\text { enforcement decisions with } \\
\text { respect to regulatory breaches } \\
\text { and offences committed under } \\
\text { the FSCA and the regulatory } \\
\text { legislation. } \\
\text { The Investment Business } \\
\text { Division began on-site } \\
\text { inspections in June } 2008 \text {. By } \\
\text { December, } 2009,13 \text { inspections } \\
\text { had been completed. }\end{array}$ \\
\hline Principle 11 & $\begin{array}{l}\text { The legislative language relating } \\
\text { to information sharing should be } \\
\text { broadened to eliminate any need } \\
\text { for the foreign regulator to be } \\
\text { exercising powers and duties } \\
\text { corresponding to those granted } \\
\text { the FSC under the listed BVI } \\
\text { financial services legislation. }\end{array}$ & $\begin{array}{l}\text { The Commission has } \\
\text { comprehensive information } \\
\text { sharing mechanisms in place and } \\
\text { is empowered to provide } \\
\text { assistance to other regulatory } \\
\text { authorities through S.33C and } \\
\text { 33D of the FSCA. }\end{array}$ \\
\hline Principle 16 & $\begin{array}{l}\text { FSC should make an assessment } \\
\text { of the quality of the accounting } \\
\text { principles and auditing standards } \\
\text { applicable in a jurisdiction before } \\
\text { approving an auditor or } \\
\text { recognizing a jurisdiction under } \\
\text { the MF Act. The standards and } \\
\text { principles should be equivalent to } \\
\text { those of the IASB. }\end{array}$ & $\begin{array}{l}\text { An audit cannot be approved } \\
\text { unless it complies with Division } 6 \\
\text { of the Regulatory Code which } \\
\text { outlines the recognized } \\
\text { accounting and auditing } \\
\text { standards that may be used by } \\
\text { licensees in the preparation of } \\
\text { financial statements. } \\
\text { The Code requires the members } \\
\text { or controlling persons of auditors } \\
\text { to be qualified, in that they must } \\
\text { belong to the specified } \\
\text { professional bodies listed in } \\
\text { section } 56 \text { (1) of the Code, } \\
\text { namely the Institutes of } \\
\text { Chartered Accountants of } \\
\text { England and Wales, Scotland or } \\
\text { Ireland, the Association of } \\
\text { Certified Chartered Accountants, } \\
\text { Canadian Institute of Chartered } \\
\text { Accountants and the American } \\
\text { Institute of Certified Public } \\
\text { Accountants. Other recognized } \\
\text { international accounting } \\
\text { standards/institutions may be } \\
\text { approved by the Commission on }\end{array}$ \\
\hline
\end{tabular}




\begin{tabular}{|c|c|c|}
\hline Reference Principle & Recommended Action & Updated Response \\
\hline & & $\begin{array}{l}\text { a case by case basis. } \\
\text { Moreover, the Code requires } \\
\text { licensees to ensure that their } \\
\text { financial statements are prepared } \\
\text { in accordance with IFRS, UK } \\
\text { GAAP, U. S. GAAP, or Canadian } \\
\text { GAAP. Similarly, the Mutual Fund } \\
\text { Regulations require funds to audit } \\
\text { their financial statements to the } \\
\text { standards identified above. } \\
\text { With respect to auditing } \\
\text { standards in recognized countries } \\
\text { or jurisdictions, the Commission } \\
\text { makes an assessment of the } \\
\text { auditing standards in the } \\
\text { jurisdictions concerned and } \\
\text { seeks to ensure that they } \\
\text { conform to the RC standards. }\end{array}$ \\
\hline Principle 17 & $\begin{array}{l}\text { Mutual fund conflicts of interest } \\
\text { should be dealt with more } \\
\text { comprehensively. All of the } \\
\text { relationships between the } \\
\text { managers, administrators, other } \\
\text { functionaries and service } \\
\text { providers should be required to be } \\
\text { disclosed. } \\
\text { Mutual funds, managers and } \\
\text { administrators should be required } \\
\text { to file annual audited financial } \\
\text { statements with the FSC. } \\
\text { Managers and administrators } \\
\text { should also be required to file } \\
\text { other regulatory reports. } \\
\text { Institute a program of regular } \\
\text { inspections of all of these entities. }\end{array}$ & $\begin{array}{l}\text { The Public Funds Code sets out } \\
\text { a requirement for the disclosure } \\
\text { of conflicts of interest, including } \\
\text { conflicts among the various } \\
\text { functionaries. In addition, the } \\
\text { Regulatory Code requires } \\
\text { licensees in having due regard } \\
\text { to customers interests to } \\
\text { manage its conflicts of interests } \\
\text { fairly. } \\
\text { SIBA and the Mutual Fund } \\
\text { Regulations require mutual } \\
\text { funds, managers and } \\
\text { administrators to file audited } \\
\text { financial statements with the } \\
\text { Commission within } 6 \text { months of } \\
\text { their financial year end. In } \\
\text { addition, funds have been } \\
\text { required by law since October } \\
2009 \text { to file the Mutual Fund } \\
\text { Annual Return. Among other } \\
\text { things, the return requires the } \\
\text { filing of valuation and financial } \\
\text { information. } \\
\text { The Investment Business } \\
\text { Division began on-site } \\
\text { inspections in earnest in June } \\
2008 \text {. To date } 13 \text { inspections } \\
\text { have been completed. As a } \\
\text { matter of course some funds are }\end{array}$ \\
\hline
\end{tabular}




\begin{tabular}{|c|c|c|}
\hline Reference Principle & Recommended Action & Updated Response \\
\hline & & $\begin{array}{l}\text { inspected through the conduct of } \\
\text { inspections on the administrator. } \\
\text { Most funds and managers are } \\
\text { nonresident and no global } \\
\text { standard or framework exists for } \\
\text { the conduct of inspections on } \\
\text { these nonresident entities. }\end{array}$ \\
\hline \multirow[t]{3}{*}{ Principle 18} & \multirow[t]{3}{*}{$\begin{array}{l}\text { Impose specific requirements } \\
\text { regarding books and records and } \\
\text { asset segregation requirements } \\
\text { that apply to all functionaries } \\
\text { (managers, administrators, } \\
\text { custodians and any other service } \\
\text { providers) who hold BVI registered } \\
\text { public mutual fund assets. }\end{array}$} & $\begin{array}{l}\text { SIBA set out the requirements for } \\
\text { all licensees, including fund } \\
\text { managers and administrators, to } \\
\text { maintain relevant records. In } \\
\text { addition the Regulatory Code } \\
\text { sets out additional requirements } \\
\text { on record keeping. }\end{array}$ \\
\hline & & $\begin{array}{l}\text { With respect to segregation of } \\
\text { clients' monies, SIBA sets out the } \\
\text { requirement for client assets to } \\
\text { be identified, appropriately } \\
\text { segregated and accounted for. It } \\
\text { is buttressed by the Regulatory } \\
\text { Code which sets out the general } \\
\text { obligations for customer assets to } \\
\text { be identified, and appropriately } \\
\text { segregated. It also sets out } \\
\text { requirements to ensure that } \\
\text { monies are not comingled, and } \\
\text { that there are proper safekeeping } \\
\text { arrangements in place. }\end{array}$ \\
\hline & & $\begin{array}{l}\text { In addition, the draft Mutual } \\
\text { Funds Regulations under SIBA } \\
\text { requires that a custodian be } \\
\text { functionally independent of its } \\
\text { manager and its administrator. } \\
\text { Consequently, assets held by the } \\
\text { custodian in the name of the } \\
\text { fund, are separate and distinct } \\
\text { from its functionaries. }\end{array}$ \\
\hline \multirow[t]{2}{*}{ Principle 19} & \multirow{2}{*}{$\begin{array}{l}\text { Issue prospectus regulations for } \\
\text { public mutual funds. } \\
\text { Require public mutual funds to } \\
\text { make immediate disclosure of any } \\
\text { material changes and to make } \\
\text { these changes known to investors } \\
\text { in a timely fashion. } \\
\text { Statutory liability for } \\
\text { misrepresentations in a mutual } \\
\text { fund prospectus should be }\end{array}$} & $\begin{array}{l}\text { Prospectus requirements are } \\
\text { contained in the draft Public } \\
\text { Funds Code that is to be enacted } \\
\text { under SIBA }\end{array}$ \\
\hline & & $\begin{array}{l}\text { SIBA requires public funds to: } \\
\text { where any required disclosures } \\
\text { cease to be accurate, register an } \\
\text { amended prospectus with the } \\
\text { Commission within } 14 \text { days of the } \\
\text { change and, when registered, to }\end{array}$ \\
\hline
\end{tabular}




\begin{tabular}{|c|c|c|}
\hline Reference Principle & Recommended Action & Updated Response \\
\hline & $\begin{array}{l}\text { extended to all parties involved in } \\
\text { preparing or authorizing the } \\
\text { prospectus. }\end{array}$ & $\begin{array}{l}\text { provide a copy to each of its } \\
\text { investors. } \\
\text { Under the MF Act and of SIBA } \\
\text { statutory liability is extended to } \\
\text { the fund, its directors or other } \\
\text { governing body of the fund. }\end{array}$ \\
\hline Principle 20 & \multicolumn{2}{|c|}{$\begin{array}{l}\begin{array}{l}\text { Enact binding rules on mutual fund } \\
\text { asset valuations and related } \\
\text { disclosure provisions. }\end{array} \\
\begin{array}{l}\text { Prohibit public mutual funds from } \\
\text { ceasing to redeem its securities } \\
\text { without notification to the FSC. }\end{array} \\
\text { for valuations and where they } \\
\text { will be undertaken the } \\
\text { frequency of valuations, and } \\
\text { circumstances in which they } \\
\text { could be specially valued the } \\
\text { basis for valuation, including } \\
\text { methodology and procedures } \\
\text { for undertaking the valuation } \\
\text { and indication of the } \\
\text { circumstances in which } \\
\text { valuation can be suspended. }\end{array}$} \\
\hline
\end{tabular}




\section{Table 18. Recommendations Relevant to the IBC and Trust and Company Service Provider Sector}

\begin{tabular}{|c|c|c|}
\hline Findings & Action Plan & Updated Follow Up \\
\hline $\begin{array}{l}\text { Ensure continuing and enhanced } \\
\text { compliance with current draft of } \\
\text { OGBS Statement of Best } \\
\text { Practice. }\end{array}$ & $\begin{array}{l}\text { Monitor and measure Bank \& } \\
\text { Fiduciary Services Division } \\
\text { policies and implementation } \\
\text { against OGBS Draft } \\
\text { Methodology Document. }\end{array}$ & $\begin{array}{l}\text { The Commission has fully } \\
\text { implemented the OGBS } \\
\text { Statement of Best Practice } \\
\text { and has addressed the } \\
\text { recommendations from the } \\
2004 \text { report. }\end{array}$ \\
\hline $\begin{array}{l}\text { More detailed and structured on- } \\
\text { site inspection of CSPs needed } \\
\text { to be able to take action where } \\
\text { there may be evidence of } \\
\text { noncompliance. }\end{array}$ & $\begin{array}{l}\text { Introduce a staff a secondment } \\
\text { program with the local CSP } \\
\text { industry and auditing firms. }\end{array}$ & $\begin{array}{l}\text { The Commission has taken } \\
\text { the approach of providing } \\
\text { secondment opportunities for } \\
\text { its staff with other overseas } \\
\text { regulators. Staff has spent } \\
\text { time at the authorities in } \\
\text { Gibraltar, Jersey, Isle of Man, } \\
\text { the Netherlands, and at GAM } \\
\text { in Ireland. Additionally, one } \\
\text { member of staff has } \\
\text { undertaken a domestic } \\
\text { attachment with BDO Binder } \\
\text { (BVI). } \\
\text { Additionally, an On-site } \\
\text { Inspections Coordinator was } \\
\text { recruited in January } 2007 \text {, } \\
\text { and now heads up the } \\
\text { inspection team consisting of } \\
\text { regulators from each Division } \\
\text { who conduct the on-site } \\
\text { inspections and produce the } \\
\text { inspection reports. }\end{array}$ \\
\hline $\begin{array}{l}\text { Increased input from industry } \\
\text { needed in respect of supervisory } \\
\text { processes. }\end{array}$ & $\begin{array}{l}\text { Increase contact and } \\
\text { consultation with the BVI } \\
\text { Association of Registered } \\
\text { Agents. }\end{array}$ & $\begin{array}{l}\text { The FSC established a } \\
\text { Fiduciary and Registry Liaison } \\
\text { Committee in } 2009 \text { to consult } \\
\text { with the financial services } \\
\text { industry on relevant matters. } \\
\text { The Managing Director of the } \\
\text { FSC has quarterly roundtable } \\
\text { meetings with the presidents } \\
\text { of the various industry } \\
\text { associations. } \\
\text { The Commission also hosts } \\
\text { regular Meet the Regulator } \\
\text { Forums to update industry } \\
\text { practitioners on current issues } \\
\text { within the industry and the } \\
\text { ongoing work of the }\end{array}$ \\
\hline
\end{tabular}




\begin{tabular}{|c|c|c|}
\hline Findings & Action Plan & Updated Follow Up \\
\hline & & $\begin{array}{l}\text { Commission. The } \\
\text { presentations from these } \\
\text { MTRs are made available on } \\
\text { the Commission's website. } \\
\text { Also senior staff of the } \\
\text { Commission makes } \\
\text { appearances at CSPs } \\
\text { luncheons to make } \\
\text { presentations and hold } \\
\text { dialogue with members of the } \\
\text { industry on relevant } \\
\text { regulatory and emerging } \\
\text { international standards issues } \\
\text { that relate to or affect the } \\
\text { financial services industry. }\end{array}$ \\
\hline $\begin{array}{l}\text { Need for transaction testing both } \\
\text { as a part of on-site inspections } \\
\text { and as a requirement for internal } \\
\text { audit testing (p. 125. Vol II) }\end{array}$ & $\begin{array}{l}\text { Implementation of Transaction } \\
\text { testing }\end{array}$ & $\begin{array}{l}\text { This is now being done } \\
\text { through KReview as part of } \\
\text { on-site inspection process. }\end{array}$ \\
\hline $\begin{array}{l}\text { Need for Immobilization of bearer } \\
\text { shares }\end{array}$ & $\begin{array}{l}\text { Amendments to the IBCA and } \\
\text { BTCA }\end{array}$ & $\begin{array}{l}\text { The immobilization of bearer } \\
\text { shares was effected through } \\
\text { an amendment to the } \\
\text { International Business } \\
\text { Companies Act in } 2003 \text { and } \\
\text { the Commission began } \\
\text { accepting applications for } \\
\text { authorized custodians in } \\
2004 \text {. } \\
\text { The provisions dealing with } \\
\text { the immobilization of bearer } \\
\text { shares are set out in the BVI } \\
\text { Business Companies Act, } \\
\text { Division } 5 \text { - Immobilization of } \\
\text { Bearer Shares, sections } 67 \text { to } \\
77 \text { - and the Financial } \\
\text { Services Commission Act, } \\
\text { Part VIIA, Authorized and } \\
\text { Recognized Custodians, } \\
\text { sections } 50 A \text { to } 50 E \text {. } \\
\text { The provisions dealing with } \\
\text { grandfathered bearer share } \\
\text { companies are set out in the } \\
\text { BVI Business Companies } \\
\text { (Amendment of Schedules) }\end{array}$ \\
\hline
\end{tabular}




\begin{tabular}{|c|c|c|}
\hline Findings & Action Plan & Updated Follow Up \\
\hline & & $\begin{array}{l}\text { Order, } 2006 \text { and the BVI } \\
\text { Business Companies } \\
\text { (Amendment of Schedules) } \\
\text { Order, } 2007 . \text { Thus by virtue of } \\
\text { these Orders (specifically } \\
\text { paragraph } 34 \mathrm{~A}(1) \text { of Division } \\
5 \text { of Part IV of Schedule } 2 \text { of } \\
\text { the BVI Business Companies } \\
\text { Act), bearer share companies } \\
\text { that had not lodged their } \\
\text { bearer shares with custodians } \\
\text { or ceased the holding of such } \\
\text { shares on or before } 31^{\text {st }} \\
\text { December } 2009 \text { have had } \\
\text { their memoranda amended } \\
\text { through the operation of law } \\
\text { prohibiting them from issuing } \\
\text { bearer shares, converting } \\
\text { registered shares to bearer } \\
\text { shares or exchanging shares } \\
\text { for bearer shares }\end{array}$ \\
\hline $\begin{array}{l}\text { Requirement for Professional } \\
\text { Indemnity Insurance for licensing } \\
\text { of CSPs (p53, Vol I) }\end{array}$ & $\begin{array}{l}\text { Inclusion of this requirement in } \\
\text { licensing regime }\end{array}$ & $\begin{array}{l}\text { Requirement is set out in } \\
\text { Section 160(1) of the } \\
\text { Regulatory Code. }\end{array}$ \\
\hline $\begin{array}{l}\text { External Auditors do not have } \\
\text { statutory protections necessary to } \\
\text { report to the competent authority } \\
\text { (p54, Vol I) }\end{array}$ & $\begin{array}{l}\text { Amendment of necessary laws } \\
\text { for the provision of these } \\
\text { protections }\end{array}$ & $\begin{array}{l}\text { Section } 17 \mathrm{I}(4) \text { of both the } \\
\text { Banks and Trust Companies } \\
\text { Act and the Company } \\
\text { Management Act provides } \\
\text { immunity for an auditor. }\end{array}$ \\
\hline $\begin{array}{l}\text { Need for implementation of } \\
\text { regular compliance and on-site } \\
\text { program (p.52, Vol II) }\end{array}$ & $\begin{array}{l}\text { Establishment of regular } \\
\text { compliance and on-site program }\end{array}$ & $\begin{array}{l}\text { The KReview on-site } \\
\text { inspection process began in } \\
2004 \text {. Since } 2005,78 \\
\text { inspections have been carried } \\
\text { out by the Banking and } \\
\text { Fiduciary Services Division. }\end{array}$ \\
\hline
\end{tabular}




\section{Table 19. Recommended Action Plan to Improve Compliance of the Basel Core Principles}

\begin{tabular}{|c|c|c|}
\hline Reference Principle & Recommended Action & Response of Authorities \\
\hline $\begin{array}{l}\text { Legal framework for bank } \\
\text { supervision(CP 1.3) }\end{array}$ & $\begin{array}{l}\text { Place the Development Bank } \\
\text { under the full authority of the } \\
\text { FSC. }\end{array}$ & $\begin{array}{l}\text { The National Bank of the Virgin } \\
\text { Islands is now licensed and } \\
\text { supervised by the FSC. }\end{array}$ \\
\hline $\begin{array}{l}\text { Prudential Standards (CP } \\
5,6,7,8,9,10,11,12,13)\end{array}$ & $\begin{array}{l}\text { Implement prudential standards } \\
\text { consistent with international } \\
\text { standards and in manner to } \\
\text { protect the safety and } \\
\text { soundness of the system and } \\
\text { the interests of depositors and } \\
\text { creditors. }\end{array}$ & $\begin{array}{l}\text { These deficiencies have been } \\
\text { addressed. On branches the FSC } \\
\text { has opted for requiring a capital } \\
\text { equivalent account maintained at } \\
\text { head office and consisting of liquid } \\
\text { assets. The amount is } 12 \text { percent of } \\
\text { assets. On Basel II; plans are to } \\
\text { implement the standardized } \\
\text { approach. A timetable has not been } \\
\text { fully established. } \\
\text { Banks are required to have in-place } \\
\text { comprehensive risk management } \\
\text { policies and processes to identify, } \\
\text { evaluate, monitor and mitigate risks. } \\
\text { Additional changes under the } \\
\text { Regulatory Code will address } \\
\text { remaining issues. }\end{array}$ \\
\hline Internal Control and Audit (CP 13) & $\begin{array}{l}\text { Implement Corporate } \\
\text { Governance Standards and } \\
\text { formal requirements for internal } \\
\text { audit. }\end{array}$ & $\begin{array}{l}\text { Section } 34 \text { of the Regulatory Code } \\
\text { requires each bank to appoint an } \\
\text { internal auditor. }\end{array}$ \\
\hline $\begin{array}{l}\text { On-site and off-site supervision (CP } \\
16,18)\end{array}$ & $\begin{array}{l}\text { Implement on-site supervisory } \\
\text { program and implement changes } \\
\text { to off-site supervisory reporting } \\
\text { and analysis. }\end{array}$ & $\begin{array}{l}\text { The FSC has established a full on- } \\
\text { site and off-site supervision program. }\end{array}$ \\
\hline Information Validation (CP 19) & $\begin{array}{l}\text { As part of the implementation of } \\
\text { on-site supervision, include the } \\
\text { verification of regulatory } \\
\text { reporting with bank records. }\end{array}$ & $\begin{array}{l}\text { Such verification is achieved through } \\
\text { the on-site inspection regime. }\end{array}$ \\
\hline Off-site supervision (CP 18) & $\begin{array}{l}\text { Design methodology and add } \\
\text { resources for effective and } \\
\text { comprehensive understanding } \\
\text { and analysis of audit and } \\
\text { regulatory reports. Should } \\
\text { continuously coordinate with } \\
\text { home supervisor. }\end{array}$ & $\begin{array}{l}\text { A comprehensive system of off-site } \\
\text { supervision, supported by an off-site } \\
\text { inspection manual, is in place. }\end{array}$ \\
\hline
\end{tabular}




\begin{tabular}{|c|c|c|}
\hline Reference Principle & Recommended Action & Response of Authorities \\
\hline $\begin{array}{l}\text { Cooperation with Other Supervisors } \\
\text { (CP24) }\end{array}$ & $\begin{array}{l}\text { The FSC may consider } \\
\text { increasing interaction with home } \\
\text { country supervisors to increase } \\
\text { understanding of the } \\
\text { consolidated entity, risks } \\
\text { assumed and effectiveness of } \\
\text { on-site/off-site supervision. }\end{array}$ & $\begin{array}{l}\text { The FSC participates in a supervisory } \\
\text { college for two of its main banks and } \\
\text { is in frequent contact with the home } \\
\text { regulator for two other banks. The } \\
\text { FSC participates in the CGBS, OGBS } \\
\text { and ASBA and other international } \\
\text { fora. }\end{array}$ \\
\hline
\end{tabular}

